Euskal ikerketen aldizkaria | Revue d'études basques |

Revista de estudios vascos | Basque studies review

$5 \mid 2000$

Numéro V

\title{
Gogoetak 'hitzen ordena eta esaldien egitura informatiboaz' prosodiaren laguntzaz
}

Begiratu bat nork bere buruaren aurkezpen esaldiei

Victor Hidalgo Eizagirre

\section{OpenEdition}

Journals

Édition électronique

URL : http://journals.openedition.org/lapurdum/1296

DOI : 10.4000/lapurdum.1296

ISSN : 1965-0655

Éditeur

IKER

Édition imprimée

Date de publication : 1 octobre 2000

Pagination : 113-166

ISBN : 2-84127-161-7

ISSN : 1273-3830

Référence électronique

Victor Hidalgo Eizagirre, «Gogoetak 'hitzen ordena eta esaldien egitura informatiboaz' prosodiaren laguntzaz », Lapurdum [Linean], 5 | 2000, Sarean emana----an 01 juin 2009, kontsultatu 03 juillet 2020 URL : http://journals.openedition.org/lapurdum/1296; DOI : https://doi.org/10.4000/lapurdum.1296 


\section{Gogoetak 'hitzen ordena eta esaldien egitura informatiboaz' prosodiaren laguntzaz}

Begiratu bat nork bere buruaren aurkezpen esaldiei ${ }^{1}$

Victor Hidalgo Eizagirre

UMR 5478

\section{Sarrera}

Zerikusi hertsia ohi dute esaldiaren intonazioak eta esaldi honek diskurtsoan jokatu ohi dituen funtzio pragmatikoek. Intonazio bidez bereizi ohi dira esaldi deklaratzaileak eta galderak. Agindu esaldiek intonazio berezia izan ohi dute. Intonazioak nabarmen adierazi ohi du hiztunaren jarrera subjektiboa ere esaten ari denaren gainean, eta baita ere, besteak beste, hiztunak bere hizketa txanda amaitutzat ematen duen edota jarraitzeko asmoa duen.

Era berean suposatu ohi da intonazioak lotura estua duela esaldiaren barne egitura informatiboarekin. Hau da, intonazioak (ere) lagundu ohi duela argitzen esaldi atalen arteko garrantzia informatibo erlatiboa, testuinguru jakin bakoitzean : osagai batzuk gailenduz, eta beste batzuk bigarren maila batera atzenduz. Gauza bat $\mathrm{da}$, ordea, uste orokorra, eta beste bat, zuzen ezagutu ahal izatea bien arteko lotura estu hori zehatz zer den, eta nola gauzatzen den kasu bakoitzean mezu hartzailearen laguntzan. Azken urteetan gaiari eskainitako ikerketak ugaritu dira, ${ }^{2}$ baina ez dirudi ilunak gehiegi argitu direnik. Artikulu honetan ${ }^{3}$ hurbildu nahi izan gatzaizkio gaiari euskarazko esaldi mota zehatz bat zabal aztertuz.

\subsection{Intonazio azterketen arazo batzuk}

Intonazioaren eta prosodiaren azterketa ez da erraza. Hiztunen hizketa natural arruntean ez dira erraz lortzen esaldi bilduma elkarren konparagarriak eta ikerlariak desio dituen aldakiak jokatzen dituztenak. Intonazio ikerlariek maizenik jo dute, hiztun gutxi batzuk hartuta, hauei irakurraraztera beraiei komeniko esaldi aldaki bildumak, aldez aurretik paperean idatziak. Azterketok, ${ }^{4}$ noski, badituzte alde onak, baina ahul batzuk ere bai, guk azpimarratu nahi ditugunak.

Arruntki oso hiztun gutxiren mostrak jaso ohi dira, nahiz gero liburu osoak idatzi, 2, 3 edo 4 hiztunen intonazioa baino aipatu gabe, hizkuntza osoaren era- 
kusgarri bailiran. Okerrena da testu irakurrien azterketa, gehienera ere, irakurketako intonazioarena dela. Ez hiztunaren hizketa naturalarena. ${ }^{5}$ Irakurketan, hiztunak ez du diskurtsoaren segida planifikatu beharrik, eta planifikazioa da intonazio unitateen egituran nabarmen eragiten duen faktorea. Nolanahi, irakurketan bertan ere, zeharo desberdin da, irakurleak testu luze koherente bat irakurtzea berau ezagutzen ez duen entzule hipotetiko bati, honi prosodiaren bidez testua errazago ulertzeko klabeak eskainiz, edota azterlariaren aurrean irakurtzea' beronek irakurleak baino hobeto ezagutzen duen esaldi laburra, irakurleak dakien bezala. Ez planifikatzeaz gainera, irakurleak ez du sikiera saiatu behar entzuleari bere mezua ulertarazten. Komunikazioa, irakurri gabe ere, egina da. ${ }^{6}$ Eta zerbait ongi komunikatu beharra da intonazio unitateen egituran nabarmen eragiten duen bigarren faktorea. Gehienean, irakurritako esaldiak solteak dira, testu-aurrerik gabekoak (grabaketa frogarenaz gain), eta hiztun bakoitza, hoberenera, bere testu-aurre' propioa irudikatzen saiatuko zaie, azterlariaren erabat kontrolez kanpo utziz aldakia. Halako grabaketa saioetan, hiztunak, arruntki, saio berean irakurri behar izaten ditu antzeko esaldi sailak, bata bestearen atzetik, elkarren arteko interferentziak suposa litezkeelarik. Aipatu kontuek zenbaterainoko eragina duten intonazio kurben egituraketan intonazio unitate bakoitzean, zail da ezagutzen, baina ziur da zalantza gabeko eragina dutela hiztun-irakurleak esaldiari eragindako intonazio unitateen banaketan, parametro ezin garrantzi handiagokoa.

\section{Gure azterketa corpusa}

Gu saiatu gara halako eragozpenak ahal bezainbat saihesten azterketa honetan. 127 hiztunen 127 esaldi konparagarri aztertu ditugu, nork bere buruaren aurkezpenean erabiliak, batez ere beren izena emateko. Horietako 91 dira Euskararen bidean bideo sailean (Lavender Films, 1989-1993), hegoaldeko euskal eskualde guztietako 91 herritan eginiko grabaketetatik atereak. Hiztun bakoitzak bere (herriko?) ohiko moduan hitz egin beharko luke kameraren aurrean (jakinda grabazioa jende aurrean erakutsiko dela), asmoarekin, entzuten duen hura herri hartako edo inguruko hizketa moldeaz jabe dadin. Hiztunek, oro har, bere istorio propioak edo herri edo ingurukoak kontatzen dituzte, baina hasi aurretik guztiek aurkeztuko dute bere burua bere modura : Ni' halakoa naiz, halako lekutakoa, hainbeste urtekoa, halako lekutan bizi dena, eta kontatuko dizuet Ö Hasierako esaldietako bat dute izena (izen-abizena) aurkezteko, ez derrigorrez aurrenekoa, eta hori aztertuko dugu guk. Hiztun guztiak dira hitz errazekoak. Baina batzuk gazteak, euskara batuan ikasiak ; eta besteak adin gehixeagokoak, euskara batua gehiegi ezagutzen ez dutenak. Noski, hiztun guztiak bide dira gauza gaztelaniaz ere (ongi) moldatzeko. Beharbada hiztunak aurretik eduki lezake prestatua bere diskurtsoa (gure azterketako aurkezpen esaldia ere), baina kamera aurrean ageri denean bat-batean ari da hizketan, paperik gabe, eta ez zaio inori nabari buruz kontatzen ari denik aurretik idatzitako eta ikasitako ezer (eta hori euskaraz oraindik nabarmentzen da).

Beste 35 hiztunen 35 esaldi jaso ditugu Euskadi Irratian 1992ko udal hauteskundeen inguruan Euskal Herri osoko hainbat alkateri eginiko grabaketetatik (iparraldeko alkate bi tarteko). Alkate bakoitza mintzoko da bere herriaz, eta saio 
hasieran egiten du bere buruaren aurkezpena, izen-abizenak emanez, eta gehienean kargua ere aipatuz herrian. Bakarren batek, nabari da, bere saiorik gehientsuena irakurtzen du. Eta pentsatu behar grabaketa egitean askok dituztela aurrean hainbat ohar idatzi gidoi modura, baita beharbada aurkezpen esaldiaren ingurukoa ere, nahiz seguru asko ez izan esaldia osorik idatzia mikrofono aurrean irakurtzeko.

127. esaldi bat ere bai, gerok Iruñean jasoa Oderitz Nafarroako Larraungo udalerriko hiztun bati. Guztira 64 esaldi bizkaieradunek eginak (Gipuzkoa Arabako bizkaierak barne). 39 gipuzkeradunak (Nafarroako gipuzkera barne). 18 goi-nafarrerako hiztunenak (Gipuzkoakoa barne). Lapurteradunenak 4 (Arbona eta Senpereko alkateak, Zugarramurdi eta Etxalarko hiztunak). Behe-nafarrerazko bat (Luzaidekoa). Eta aezkerako bestea (Orbara).

\section{Aztertu esaldi egiturak}

127 esaldietatik 112 dira naiz aditz flexio soilaren bidez burutuak, ordena aukera desberdinetan. $9 \mathrm{k}$ dute nire izena $(\ddot{O})$ da $(\ddot{O})$ egitura. $4 \mathrm{k}$ izen $(a)$ dut itxurakoa. lek Ondarruko zait izena egitura (gasta isena ; ik. (10) adibidea). Eta bakar batek ere deitzen naiz aditzaren bidezkoa. 127 esaldiok 4 molde nagusi -eta zenbait azpimolde- erakusten dituzte :

I. Izena + Aditza egiturak. Hau da : osagai bat + aditza esaldiak. Denera 9 esaldi (ik. 4.).

a. Osagai hori 4 kasutan izen soila da (2tan), edo konposatua (2tan), (1)ekoen itxuran :

(1) a. Ester naiz, ... (Eibar - N $)^{8}$ (ik. 3. irudia) $)^{9}$

b. Juan Antonio naiz, ... (Amezketa - M26) (ik. 4 irud.)

b. Beste zenbaitetan (5 esaldi) izen-abizenez osatuak, (2)koen itxuran (ik. 5.) :

(2) a. Florentino Goiburu naiz. (Idiazabal - G) (ik. 5 irud.)

b. Xalbador Zubizarreta nauk, ... (Albiztur - M) (ik. 6 irud.)

II. Izena + Aditza + Osagai gehiago. 31 esaldi. (Izena, edo Izen-abizenak.)

a. Ondoko osagai hori 2 kasutan oso laburra da ( $n i$ izenordea), (3)koaren itxuran (ik. 6.) :

(3) Ibon nauk ni. (Azkoitia - M) (ik. 8 irud.)

b. Beste 29etako aditzak osagai luze bat, edo gehiago, du ondoretik, (4)koen itxuran (ik. 7.) :

(4) a. Inaxio Martiarena nauk, zarauztarra, ... (Zarautz - G) (ik. 10 irud.)

b. Elena naiz, hemengoa, Zugarramurdikoa, ... (Zugarramurdi - N)

(ik. 11 irud.)

Badira segidako III. sailean ere antzeko egiturak ondoretik osagaiak erakusten dituztenak. 
III. Osagairen bat aditz aurrekoaren aurre + Izena (edo) + Aditza (+Osagai gehiago). Denera 50 esaldi. Goian bezala, izena, edo izen abizenak. Inoizka beste osagarriren bat aditzaren aurrean fokalizatuta. (ik. 8.). ${ }^{10}$

a. Gehienek dute $n i$ izenorde pertsonal soila lehen osagai. 41 esaldi (5)ekoen itxurakoak :

(5) a. Ni Elisa nas. (Busturia - E60) (ik. 24 irud.)

b. Ni Germain Ezponda naiz, Senpereko auzapeza. (Senpere - G)

b. 6 esaldik nire izena + izena + aditza $(+\ddot{O})$ egitura dute, segidakoaren itxuran:

(6) (Bueno,) nire isena Itziar da, Ö (Ondarru - N27) (ik. 26 irud.)

c. 3 esaldik izena + beste osagairen bat + aditza egitura erakusten dute, (7)koaren itxuran :

(7) Rejina, Orbarakoa niz, Ö (Orbara - E) (ik. 27 irud.)

Aipatu I, II, III multzoetako esaldi guztiek gordetzen dute galdegaia + aditza deitu egitura. Corpuseko 127 etako 94 esaldik. Atalotan aipatu 90 esaldiei, (8), (9), (10)ekoak erantsi behar :

(8) a. (Bueno,) ni(k) Josu izena dit, ... (Zestua - M) (ik. 31 irud.)

b. Iñigo Uribetxeberria izena diat, ... (Azpeitia - M)

(9) (..., ta, bueno,) Juantxo Apezetxea izen dut. (Goizueta - M)

(10) (Bueno,) ni(r)i Lurdes gasta isena. (Ondarru - N28) (ik. 32 irud.)

IV. $(\ddot{O}+)$ Aditza + Izena (+ Ö) ordenamenduarekin, guztiz bestelako egitura informatiboa erakusten dute corpuseko beste 33 esaldiek. Aditza + galdegaia esan ohi da (ik. 9.).

a. Egitura arruntena da (22 esaldi) ni naiz lokuzioaren ondoren izena (izen-abizenak) eta agian beste hainbat osagai ematen dituena, (11)ko esaldien itxuran :

(11) a. Ni naiz Manuela Iantzi, Lesakakua. (Lesaka - E) (ik. 37 irud.)

b. Ni nas Jose Mari Bilbao, Jose Anjelen anaje, Ö (Goierri (B) - G) (ik. 38 irud.)

b. 3 esaldi ditugu nire izena da + izena $(+\ddot{O})$ egitura dutenak, (12)koaren antzekoak :

(12) (Um, ba,) nire isena da Amadeo Urrutia Arriet. (San Migel -Bizkaia- G) (ik. 39 irud.)

c. Esaldi bat dugu nik izena dut + izena itxurakoa : irud.)

(13) Nik izena dut Anastasio. (Gipuzkoako Bidasoako hiztuna - G) (ik. 40

d. Beste esaldi bakar bat dugu deitzen naiz + izena itxurakoa :

(14) Deitzen, ..., naiz Juan Luis Pagaldai, ... (Mallabi - G) ${ }^{11}$ 
e. Azkenik 6 esaldi ditugu, naiz aditz trinkoa dutenak esaldi hasieran, segidakoen itxuran :

(15) a. Nas Julen Mendieta, hemeko Lemoakoa. (Lemoa - G33) (ik. 43 irud.)

b. Naiz Patxi Basauri, Elgetako alkatea. (Elgeta - G) (ik. 44 irud.)

Corpuseko esaldien \%74k erakusten du Azkue-Altubek XX. mendean predikatutako derrigorrezko hitz ordena kanonikoa (galdegaia + aditza). \%26k, alderantzizkoa. ${ }^{12}$ Ordena desberdinak egitura prosodiko desberdinekin lotuko dira. Segidan sailez sail arakatuko ditugu.

\section{Azterketan kontuan hartu beharreko}

\subsection{Prosodiaren ERAGIN OROKORRA}

Badira zenbait ohar intonazioa eta esaldien egitura informatiboen arteko loturak ikertzeari ekin aurretik egin beharreko. Hartu behar baita kontuan, mezu hartzaileari esaldi baten informazio egitura ezagutzen laguntzen diona ez dela soilik intonazioa, hau da, esaldiaren ahoskatzeak ahots kordetan eragindako dardara bibrazioen arintasuna, oinarrizko maiztasuna (F0), hertzetan neurtua $(\mathrm{Hz})$. Mezu hartzaileari, intonazioa bera bezain lagungarri izango zaio, gutxienez, berau ahoskatzean, modu batera edo bestera intonazio katean mugatuko diren intonazio unitate beregainen identifikazioa. ${ }^{13} \mathrm{Ez}$ du esanahi bera euskaraz Gaur joan da esaldiak unitate bakarrean ahoskatua (16a 17a), edota bitan (16b ; 17b), hala intonazioak baieztapena adierazten badu (16), nola galdea (17):

(16) a. GAUR joan da.

b. Gaur / JOAN da.

(17) a. GAUR joanda?

b. Gaur / JOAN da?

Eta esaldiko intonazio unitateen mugaketan zerikusi handia dute, intonazioak unitate bakoitzean eratuko duen gailurraz gainera, intonazio unitateen amaierako silaben luzerak, hauen muga intonazio bereziak, eta unitate arteko pausakerak. Horregatik nahiago dugu prosodiaren erlazioaz mintzo esaldien informazio egiturarekin, ez bakarrik intonazioarenaz. ${ }^{14} \mathrm{Hala}$ eman ohi da prosodiaren zeregin nagusitzat, hain zuzen, esaldiko intonazio unitate horien mugatzea eta taldekatzea. Azterketa honetan, saiatu gara intonazioaz gaineko beste bi faktore prosodiko horiek ere (azken silaben luzera eta pausakera) kontutan hartzen eta denak lotzen esaldi osagai bakoitzaren balio informatiboarekin.

\subsection{ZER DA ESALDIAREN INFORMAZIO EGITURA ?}

Prosodiaren eta esaldien informazio egituraren inguruko eztabaiden ilunaren arrazoi bat gehiago da, gure ustean, ohituraz hainbat azterketa arlo desberdin nahastu izana esaldiaren informazio egitura edo antzeko kontzeptuen inguruan. Gu hiru alor bereizten saiatuko gara : 
1. Batetik, propio esaldiaren informazio egitura deitu duguna, eta oro har antzinatetik $^{15}$ esaldiaren bi polotako banaketa proposatu duena. Guti goiti-beheiti : Zertaz Zer dioen esaldiak.

- Alde batetik, esaldiaren predikazio markoa ${ }^{16}$ eraikitzen laguntzen duten osagaiek osatu atala (esaldiaren ondoko predikazioa zertaz izanen den eta berori zein baldintza eta ingurumaritan proposatzen den aurretik zehazten duten osagaiak, esaldiaren aurrealdean emanak beti intonazio unitate beregainetan). Garai eta eskola desberdinetan izen desberdinak jaso ohi dituen atala, eta azken garaiotan nagusiki tema edo topiko deitua, eta gure artean mintzagai ; baina baita ere onoma, protasi, subjektu, notion initiale, subjektu psikologiko, subjektu logiko, presuposizio, hondo (background), zahar, eman, ezagun, Ö Guk : predikazio marko (pm).

- Bestalde, esaldiaren predikazio gunea osatzen duten osagaiak, beti predikazio markoaren ondoren emanak intonazio unitate beregainetan. Mezu hartzailea, atala jasotzean, berau dagoen testu-aurrearen ondoren, ase senti daiiteke esaldiko predikazioaren muina jasoa balu bezala, osotasuna, esaldia bertan bukatuta ere. Atalari errema eta komento (comment) deitu ohi zaio gaur egun maizenik, eta gure artean antonomasiaz galdegai, nahiz azken urteotan zehatzago iruzkin (irazkin) ; eta historikoki apodosi, predikatu, but de discours, predikatu psikologiko, predikatu logiko, propos, foku, asertzio, nabarmendua (foreground), berri, ezezagun, Ö Guk : predikazio gune (pg).

2. Esaldiaren informazio egitura honetatik berezitua uste dugu begiratu behar zaiola esaldi atalen enfasi edo fokalizazio egiturari, aurreko banaketarekin zerikusirik gabekoa. Hainbat fokaliza litezkeelarik predikazio markoko osagaiak, nola predikazio gunekoak. Foku eta galdegai terminoak erabili dira fenomenoa aipatzeko. Nahiago dugu intonazio unitateen gailur intonatiboz, edo prosodiko-predikatiboz hitz egin.

3. Azkenik, uste dugu, bi eremuok erabat bereizi behar direla, esaldiko osagai bakoitzak, berez eta bere testu-aurre zehatzaren ondoren, duen balio semantikotik. Osagaiak berez du balio semantiko propioa, ${ }^{17}$ eta iragargarritasun (prebisibilitate) maila jakin bat. ${ }^{18}$ Osagaia zenbat eta usna-errazagoa izan, iragargarriagoa, orduan eta maila semantiko apalagokoa, dinamismo komunikatibo eskasagokoa, predikazio marko izan, edo predikazio gune, fokalizatua agertu edo fokalizatu gabe. Ezaugarri honen inguruan bildu ohi dira zahar (eman) / berri edo ezagun / ezezagun dikotomiak.

Aipatu 3 ezaugarriek zerikusi estua dute osagaiek esaldian erakusten duten ordenarekin, eta hala, osagai bakoitzak duen testu-aurrearekin. Guk aldakion lotura arakatuko dugu esaldi bakoitzaren ezaugarri prosodikoekin, ezagutu nahian zenbateraino erabil ditzakeen hiztunak prosodia ezaugarriok esaldiaren informazio egituraz jabetzeko. 


\section{Izena + Aditza, egiturak}

Berau da egiturarik sinpleena. Bi elementuko esaldiak, izen soil edo konposatuz eta aditzaz osatuak. 4 esaldi ditugu corpusean $:^{19}$

(18) a. Ester naiz, ... (Eibar - N) (ik. 3 irud.)

b. Mikel naiz, ... (Etxarri - M)

c. Juan Antonio naiz, ... (Amezketa - M26) (ik. 4 irud.)

d. (Bueno, e,) Jose Luis nas, ... (Lezama - G)

Inozoa dirudi (18)ko esaldien aurrean galdetzen hastea esaldi osagarri bietako zein den gailen, informatiboki garrantzitsuago, zein bietan galdegai, euskarazko ohiko terminologian. Nornahik senti genezake, aurkezpen egoera arruntean, izenak informazio kopuru handiagoa eskaintzen digula aditzak baino. Izena espezifikatzaileagoa da. Aditza, generikoago. Nornahik erabil genezake naiz aditza geure identifikazioan. Gutxiagok Ester edo Mikel espezifikoak. Izenak dira mezu hartzailearentzat aurrez usna-gaitzago, eta beraz, informatiboago.

Zailagoa da asmatzea naiz aditza informatiboki zer den. Mintzagai? Informazio zahar? Ez dirudi. Halako testuinguru batean (lekukoa kamera aurrean), osagai biak dira berri (ez bat zahar eta bestea berri) eta biak hainbat garrantzitsu, nahiz garrantzi semantiko desberdineko. Testu-aurre berean esaldion ordez aurki genitzakeen beste batzuen kontrasteak jabearazi gaitzake naiz aditz soilaren garrantzi informatiboaz. Kamera aurreko pertsonak berdin esan baitzezakeen Ester naiz-en ordez (19)ko esaldietakoren bat :

(19) a. Ester da hemen nire aldamenean, eta berak egingo dotzue berba nik baino hobeto.

b. Ester deitzen didate niri, baina izatez Maria Ezterenzubi naiz.

Baina aditza segitzen dugu sentitzen izenaren menpeko (19)ko esaldietan ere. $\mathrm{Ez}$, noski, euskaraz ondoren doalako. Gure inguruko beste hizkuntza batzuetan (Je suis Ester/Soy Ester / I am Ester, ...), ordena arrunta' aditza + izena da euskaraz ez bezala, eta ez dirudi horrek ezer aldatzen duenik amaierako izenaren gailentasun informatiboa. Hala predikatu ohi da, galdegaia + aditza egitura ote den euskarak berezko duen ordenamendua, beste hizkuntzok aditza + galdegaia luketen bitartean. Gauzak ez dira horren xinpleak.

Zergatik jabetzen gara berdin hizkuntza guztiotan, Ester izena denez esaldiko elementu garrantzitsua aditzaren gainetik, hau hasieran edo amaieran eman? Seguru asko, aipatu arrazoi semantiko soilagatik (espezifikatzaileak informazio gehiago). Kontua da, halako hierarkia predikatibo konstante batek (espezifikatzailearen prominentzia aditzaren gainetik halako testuinguruan), denboraren joanean, bere isla utzi beharko lukeela hizkuntzaren prosodian modu desberdinean ordena bat edo bestean. Eta baliteke hala izatea, baina ez dugu garbi nola.

Hasteko oraindik ez dugulako garbi hizkuntza bakoitzean zerk, zein osagarri prosodikok, ematen du(t)en aditzera osagai batzuen gailentasuna besteen gainetik. Esaldiko oinarrizko maiztasunaren gailurrak? Intonazio kurba horrek esaldian, gora edo behera, jasaten duen aldaketarik handienak? Osagaien ahoskatze inten- 
tsitateak, indarrak? Silaba gailenduen iraupen luzeagoak ? ${ }^{20}$ Bada zer aztertua, eta ez euskaraz bakarrik.

\subsection{ZENBAT EZAUGARRI PROSODIKO: INTONAZIO UNITATE BAKARRA}

(18)ko lau esaldiak laburrak dira. 500/700 ms bitartekoak, segundo erdia eta hiru laurdenak arteko iraupenekoak, 3-5 silaba bitartekoak. ${ }^{21}$ Ezaugarri garrantzitsuena dute intonazio unitate bakarrean ahoskatuak izatea, osagai guztiak aho kolpe bakar batean emanak, intonazio gailur nagusi bakar baten pean antolatuak (txapel edo angelu bakar baten pean : ^), batere barne pausa, eten edo mugarik gabe (ik. 1 eta 2 irudietako esaldiak, adibide). ${ }^{22}$ Aldiz, unitateek, aurretik eta ondoretik, pausa, eten edo muga argiak erakutsiko dituzte. ${ }^{23}$ Hiztuna lau estrategiaz baliatu ohi da mezu hartzailea jabe dadin, ezarian baina zalantzarik gabe, intonazio unitateen arteko muga horietaz (ik. Cruttenden 1986 (1997); Hidalgo 2000b, c) :

1. Nabariena, hiztunak pausa eragitea intonazio unitatearen amaieran. Pausa hutsa (isilunea) edo betea (soinu berezi luzaturen bat tartekatuz bi unitateen artean : $a, e, m, u m$ edo antzeko). Pausa bat aurkitzen dugun guztian izango gara intonazio unitateen arteko muga baten aurrean. ${ }^{24}$ Pausa, nolanahi, ez da beti ezaugarririk ohikoena intonazio unitateen arteko mugan, nahiz kasutan oso arrunta izan.

2. Pausaz edo pausa gabe, unitate bateko azken silaba (edo azken bokala edo kontsonantea) oso maiz luzatu ohi da neurriz kanpo, eta eten seinale nabaria gertatzen da.

3. Maizenik luzatua, intonazio unitate bateko azken silabak muga intonazio berezia jaso ohi du, goranzkoa edo beheranzkoa, unitateko intonazio gailurrekoaz landa.

4. Intonazio unitate bakoitzak bere intonazio gailur propioa du (eta bi unitatek, bi gailur) ${ }^{25}$ Tarteko mugan, edo ondoko unitatearen lehen silaba ez nuklearrean, intonazioaren jausia gertatu ohi da, nabarmena edo ez hain nabarmena, gero berriro errekuperatzeko gailur berriranzko bidean. ${ }^{26}$

Gure corpusean galdegaia + aditza egitura intonazio unitate berean ematen duten esaldi guztietan (94 esaldietako ia guztiak ; salbuespenetarako ik. 5.), bat datoz unitateko intonazio gailurra eta aditzaren aurreko osagaiaren gailur prosodikoa, azentua daraman silaba : nukleoa ${ }^{27}$ (ik. 1 eta 2 irud. ; baita ere 32 irudia bitarteko gehienetan). ${ }^{28}$ Gailurra, nolanahi, nukleoko silabaren amaieran azaldu ohi da, eta are hurrengoaren hasieran ; ez justu nukleoaren gainean. Nukleo aurreko silabak, intonazio unitate berean, maldan gora ageri ohi dira nukleoko gailurrerantz. Nukleo ondoretiko silabak, berriz, intonazio unitate berean, maldan behera ; bai, nukleoaren sintagma berekoak, nola, garrantzitsu dena, aditza bera ere, oinarrizko maiztasuna galtzen doan isats prosodiko (eta predikatibo) deazentuatuan ${ }^{29}$ (hori guztia suma liteke 1,2 irudietan).

Beti, hala ere, ez da horren garbi sumatzen gorakada-tontor-beherakada intonatibo hori. Batzuetan intonazio kurba bere maila gorenean hasten delako jada, lehen silaba izaki unitate nukleoa. Bestetan ez da garbi sumatuko nukleoaren 
ondoko beherakadarik, beharbada, gailurrak bat egiten duelako azken silabaren goranzko muga intonazio propioarekin. ${ }^{30}$

\subsubsection{Intonazio unitateko azken silabaren muga intonazioaz}

Intonazio unitateko azken silabak erakutsi ohi dituen intonazio ezaugarri propioak, esanahi informatibo bereziekin lotu ohi dira, joera unibertsal bailiran :

1. Tonua, gailurretik behera datorren beheranzko intonazio etengabearen segida gertatzen bada, edo artean beherago amildu, oro har, predikazioaren amaiera iragarpentzat hartu ohi da. Hala, 1 eta 2 irudietako esaldietan ${ }^{31}$. Guk amaierako beherakada hori islatu nahi izan dugu esaldi amaierako puntu ortografikoarekin.

2. Intonazioaren gorakada nabarmena gertatzen bada, intonazio unitateko gailur intonatiboa bera baino askoz gorago igo litekeena, oro har, predikazioaren jarraipen seinaletzat hartu ohi da ondoko intonazio unitateetarako (esaldi berekoak edo berri batekoak) $)^{32}$. Amaierako goranzko intonazioa, koma ortografikoz adierazi dugu. Suma liteke azken gorakada nabarmena 3, 4 edo 6 irudietako esaldien amaieran. ${ }^{33}$

\subsection{EUSKARAZ : GAILUR INTONATIBO = GAILUR PROSODIKO = GAILUR PREDIKATIBO}

Badirudi euskaraz bat egin ohi dutela intonazio unitateko gailur intonatiboak, prosodikoak eta predikatiboak, intonazio unitatearen hasierako osagaian. Horixe $\mathrm{da}$, hain zuzen, hiztunak euskaraz duen aukera elementu bat fokalizatzeko : unitate hasieran eman. ${ }^{34}$ Intonazio unitatea planifikatzen ari denean, hiztunak, nahita edo ezarian, beti erabakiko du intonazio unitatearen hasierako gailurrean ematea azpimarratu nahi duen osagaia eta ez beste bat. Horregatik dira euskaraz horren desberdinak segidako esaldiak, biak ere intonazio unitate bakarrean emanda :

(20) a. Ester etorri da.

b. Etorri da Ester.

Bakoitzak osagai desberdina azpimarratzen du unitate hasierako gailur intonatibo-prosodiko-predikatiboan, eta ondokoa unitateko isats intonatibo-prosodiko-predikatiboan emango du nabarmen deazentuaturik, (21)eko itxuran :

(21) a. [esTER etorri da] $]^{35}$

b. [eTOrri da ester]

Bi esaldien intonazio kurbak, suposaturik amaierako silabak beheranzko intonazioa duela, itxura berekoak izanen dira (gailur intonatiboa bigarren silaban, eta hortik behera isats intonatibo luzea amaierarantz) :

$$
\begin{aligned}
& \text { esTER etorrida } \\
& \text { eTORRidaEster }
\end{aligned}
$$

Eta zer gertatzen da aipatu inguruko hizkuntzetan Je suis Ester / Soy Ester / I am Ester bezalako segidekin, esaldiko zalantza gabeko gailur prosodiko-predika- 
tiboa esaldi amaieran ematen denean? Ez dugu garbi. Pentsa zitekeen kontrako ordenamenduak, kontrako egitura prosodiko eta predikatiboa eragiten dituen bezala, kontrako egitura intonatiboa eragin zezakeela (buru-aurre luze bat maldan gora amaierako nukleorantz, eta han jaitsiera azkarra). Hala gertatzen ${ }^{36}$ da batzuetan, baina ez beti. Hizkuntzotan ere intonazio gailurra maiz eman ohi da esaldi hasieran, nahiz gailur prosodiko-predikatiboa amaieran eman. ${ }^{37}$

\subsection{INTONAZIO UNITATEA INFORMAZIO UNITATE}

Hizkuntzen arteko konparaketan, bada bigarren galde interesgarri bat. Zergatik ez da gehiago kostatzen euskaraz, edo beste hizkuntzotan, esaldiok deskodetzea, prozesatzea eta ulertzea, informazio garrantzitsua hasieran eman (ESTER naiz), edo amaieran (je suis ESTER) ? Harritzeko fenomenoa litzateke, ez bageneki aurrez mezu emaileak eta hartzaileak, intonazio unitatea erabiltzen dutela oinarrizko informazio unitate bezala mezuak kodetzeko eta deskodetzeko. ${ }^{38}$

Mezu emaileak zati laburretan kodifikatzen du bere mezua azken maila lexikofonikoraino (intonazio unitateen neurrian), nahiz, garunean, egin beharreko esaldi osoaren irudi logiko eta sintaktikoa eraikia izan. Eta zati hau kodifikatua duen orduko hasiko da ematen, itxaron gabe esaldi osoa maila lexiko-fonikoan kodifikatua izateari. Atal horri intonazio segida etenik gabea emango dio, gailur intonatibo-prosodiko-predikatibo bakar baten pean antolatua : intonazio unitate bat osatu eta emango du. ${ }^{39}$ Mezu emaileak atal horretan zatitu eta kodifikatu du esaldi osoaren inguruan emateko zuen informazioa, eta beraz, zati bezala esanguratsua da. 4.3.2. atalean dihardugu atal horien kategorizazio informatiboez.

Eta mezu hartzaileak ere erabiliko du intonazio unitatea (informazio unitatea) mezuaren deskodifikaziorako unitate bezala. Lehenik eta behin, badakielako mezu emaileak unitate berori erabili duela bere informazioa kodifikatzeko unitate. Mezu hartzaileak unitatea osorik jasoko du, gailur baten inguru antolatua, eta hierarkia intonatibo, prosodiko eta predikatibo jakin batez (gailur eta isats), unitatea informatiboki deskodetzen hasi aurretik. Horrek esan nahi du, tarteko ulermen arazo lexikorik gabe, Ester etorri da bezalako unitate bat jasotzean, mezu hartzaileak ez duela lehendabizi, Ester hitza jasotzean, denbora hartzen, honi buruzko diskisizio informatiboetan hasteko, eta bere buruari esaten : " Ah! Ester aipatu didate. Eta zer esan nahi ote didate Esterriburuz? ", gero bigarren pauso batean jaso eta deskodifikatzeko etorri da atala, eta orduan ulertzeko " Ah! Etorri dela. » Prozesu hori, bai gertatzen da Ester / etorri da esaldia bi intonazio unitatetan jasotzen duenean, eta hala ulertuko du orduan Ester / ETORRI dela. Eta ez, unitate bakarrean emanda bezala, ESTER etorri dela.

Intonazio unitateekin gertatzen da, informazio egituraren inguruan, hitzekin gertatzen dena esanahiari dagokionean. Fonemak jasotzen ari garen bitartean, ez gara jakinaren gainean fonema bakoitzaren kontziente egiten, ulermen arazoren bat sortu arte. Aste(g)unetan hitza entzun edo irakurtzen dugun bitartean ez gara ari kontziente pentsatzen, garai bateko haurrak bezala, a eta s, beraz, as ; t eta e, beraz, te : as-te ; Ö. Eta, batez ere, ez gara kezkatzen hasierako a eta s, as, horren esanahiaz. Esanahiaz arduratzen gara hitzaren amaiera aldera, berau osatuxea 
dugunean, ez bitartean. Ez gara sikiera kezkatu edo konturatu ohi, astegunetan entzun dugun, edo asteunetan, ondo ulertu baitugu « astegunetan ». Ez gara fonemez kezkatzen disfuntzio bat sentitu arte : astegunetan espero dezakegun testu-aurre baten ondoren, aspeunetan jasoz, edo astounetan, orduan bihurtuko gara kontziente, badenez hor arazo bat.

Gauza bertsua gertatzen da, uste dugu, informazio unitateetan. Hitza entzun edo irakurtzean ez gara kezkatzen balio informatiboaz, baizik honen esanahi semantikoaz. Balio informatiboaz kezkatuko gara informazio unitatea amaitzeko denean, eta berau aurreko informazio unitateekin (ez hitz solteekin) lotu nahi genezanean. Gauza bera gertatuko da frantsesez, espainolez edo ingelesez Je suis Ester, Soy Ester edo I am Ester eman edo jasotzean, unitate bezala kodifikatu eta deskodifikatuko ditugu. Horregatik ez da prozesatze zailtasun berezirik hizkuntza batzuetan edo besteetan, intonazio / informazio unitateak deskodetzeko garaian, hauen gailur prosodiko-predikatiboa hasieran eman (ESTER naiz) edo amaieran (Je SUis ESTER).

\subsubsection{Intonazio / informazio unitateen garrantzia esaldien desanbiguazioan}

Esaldi barneko intonazio / informazio unitate banaketak eta hau mezu hartzaileari behar bezala ezagutarazteak ikaragarrizko garrantzia du esaldien deskodetze prozesu zuzenean. Aipatu dugu Ester etorri da, Ester / etorri da bikotearen esanahi desberdintasuna intonazio unitateen banaketa desberdinaren ondorioz (ik. 22), baita ere 3.1. atalean $(16,17)$ ko esaldi pareak (ik. 23) :

(22) a. [Ester etorri da]

b. [Ester] [etorri da]

(23) a. [Gaur joan da]

b. [Gaur] [joan da]

Intonazio unitateen mugaketa eta taldekatzearen eragina orokorra da, eta maiz laguntzen du esaldien desanbiguazioan. ${ }^{40} \mathrm{Hala}$ nola gerta litekeen, milaka adibideren artean, Beñatek ez daki zer egin duen diruarekin bezalako esaldi batekin, bi eratara interpreta litekeena, intonazio unitateen banaketa desberdin baten karian :

(24) x. Beñatek ez daki zer egin duen diruarekin

a. Beñatek ez daki zer egin duen ][ diruarekin

b. Beñatek ez daki zer egin ][ duen diruarekin

Adibideak nonahi aurki litezke. Intonazio / informazio unitatearen amaierarekin (pausa, azken silabaren luzatze, amaierako muga intonazio berezi, edo gailur berriaz) mezu hartzaileak adierazten dio mezu hartzaileari hara bitarteko zatia, informatiboki, unitate beregain bezala prozesatu behar duela dagokion gailurraren pean. Aldiz, handik aurrerakoa, unitate berri, eta gailur intonatibo-prosodikopredikatibo berri baten pean. Informazio hori, beti, ezinbestekoa da esaldien interpretazio zuzenerako. 


\subsubsection{Intonazio / informazio unitateen kategorizazio informatiboa}

Intonazio / informazio unitateen barne osagaien artean, egin genezake, bai, osagaien hierarkizazio semantikoa (berezkoa, eta betetzen duen funtzio gramatikalaren eta testu-aurrearekiko duen mendekotasun mailaren araberakoa). Baita ere prosodikoa : zein osagai ematen den unitatearen gailurrean fokalizatuta, zein honen isatsean (edota buru aurrean, gailurra amaiera aldera erakutsi ohi duten $\mathrm{AO} / \mathrm{AX}$ hizkuntzetan).$^{41}$ Ordea, intonazio / informazio unitateek ezin dute izan barne osagaien hierarkizazio informatiborik. Eta hau garrantzizko da. Esan nahi $\mathrm{da}$, intonazio / informazio unitate bateko osagaiak ezingo ditugula banan bana sailkatu batzuk mintzagai edo tema bezala eta beste batzuk iruzkin edo errema legez. Intonazio / informazio unitate bakoitzak, osorik, jokatuko du mintzagai rola, edo osorik jokatuko du iruzkin rola, diskurtsoan ageri den uneko testu-aurrearen arabera, eta ez berezko ezaugarri intrintsekoen kausaz.

Hala sailkatu ditugu guk (ik. Hidalgo 2000b, c) intonazio / informazio unitateok bi multzo nagusitan. Edota predikazio gune (pg) dira, esaldia intonazio unitate horrekin bukatuta ere, mezu hartzailea ase gera badaiteke bertan, esaldian behar zuen predikazio guztia jada jasoa balu bezala. Hori gertatzen da lehen lau irudietako esaldiekin, intonazio unitate bakarrean emanak, edota (25a) eta (26a) esaldietako unitate bakarrekin, eta (25b) eta (26b)ko bigarren unitateekin. Unitateak, bestela, ez dira izango predikazio marko (pm) baino, honek, dagoen testu-aurre horren ondoren, mezu hartzailea ase utzi ezin badu, eta esaldia bertan bukatu ezin baliteke funtsezko informazioren faltan. Hala (25b) eta (26b)ko lehen unitateekin :

(25) a. [ESTER etorri da]PG

b. [ESTER]PM [ETORRI da]PG

(26) a. [GAUR joan da]PG

b. [GAUR]PM [JOAN da]PG

\section{Izena + Abizena + Aditza, egitura konplexuxeagoak}

Halako 5 esaldi ditugu corpusean :42

(27) a. Florentino (/) Goiburu naiz. (Idiazabal - G) (ik. 5 irudia)

b. Xalbador / Zubizarreta nauk, ... (Albiztur - M) (ik. 6 irud.)

c. Juan Karlos / San Migel naiz, ... (Lekeitio - G)

d. Juan Karlos / Leturia naiz, ... (Ormaiztegi - M)

e. Pedro / Olabarrieta / Ormaetxe / naiz. (Zaratamo - G86)

Esaldiok luzexeagoak dira. Lehen laurak 900 eta 1.200 ms-ren artekoak, ${ }^{43}$ laurak 7-9 silaba artekoak. Luzera' mugakoa gertatzen da esaldiak intonazio unitate bakarrean emanak izateko. Eman litezke, eta hala uste dugu dela emana 2 irudiko Imanol Larrañaga naiz esaldia $(927 \mathrm{~ms}, 9$ sil.). (27b, c, d) esaldiak, ordea, zalantzarik gabe ematen dira 2 intonazio unitate berezituetan. Lehena, izena emateko ; bigarrena, abizena eta aditza. Ikus liteke 6 irudiko esaldian, non, pausarik ez izan arren izen abizenen artean, Xalbador izenaren azken silabak $250 \mathrm{~ms}$-ko iraupena 
duen (ohiko 110/120 ren aldean), o bokala ikaragarri luzatuz (ia berak bakarrik ditu $180 \mathrm{~ms}$ ). Entzukeran nabari da luzera berezia. Eta esaldi atal bakoitzak du bere gailur intonatibo-prosodikoa [xalBAdor] eta [zuBIzarreta], ba eta $b i$ silabetan. Lehen unitateko oinarrizko maiztasuna ez da erortzen gailur ondoren, eta bat egiten du unitateko azken silabaren gorakadarekin, predikazioaren jarraipena iragarriz (silaba amaieran sumatzen da, hala ere, jaitsi aldi bat). Bigarren unitatearen hasiera kontsonante ahoskabe batek egiten du, baina suma liteke oinarrizko maiztasuna igotzen bi silabaren amaiera aldera, handik behera abiatzeko unitateko azken silabaraino. Honek (silaba bakarreko nauk aditza) goranzko norabidea hartzen du, predikazioaren jarraipenaren iragarle (kasuan ondoko esaldi batean).

Horrek esan nahi luke, mezu hartzaileak esaldiko lehen unitatea jasotzean, atal hori bere kasa prozesatzeko instrukzioa jasotzen duela. Eta bere burua ase senti ezinda (predikazio marko), denbora izanen duela honi galdetzeko : "Eta Xalbadorrekin, zer? ». Bigarren unitateak aseko du : " Ah! Ez da edozein Xalbador, Xalbador / Zubizarreta da. Kasuan, esaldi osoaren unitate bakarreko intonazioak ez luke esanahia ezer asko aldatuko. Mezu hartzaileari aipatu hausnarketa eragin nahi edo nahi ez, hiztunak bi unitatetan eman du esaldia. Agian, nahiko luze zelako jada abizenak eta aditzak osatua (6 silaba), eta kasuan luzeegi izena unitate berean emateko ( 9 silaba). Beharbada, hiztuna hizketan hasi denean zalantza egin duelako abizena eman edo ez. Akaso, hiztunak erliebe berezi bat eman nahi izan dielako entzulearen aurrean, bai izenari, bai abizenari, hauek intonazio unitate berezituetan emanda ; ausaz Ö Antzeko hausnarketak bidera litezke $(27 \mathrm{c}, \mathrm{d})$ esaldien aurrean.

Zenbaitetan zalantza egin liteke unitate bakar edo biren aurrean ote gauden. Hori gertatzen da (27a) esaldiarekin ( 5 irudian). Florentino izenaren azken silaba luzea da (160 ms), baina ez bereziki. 2 irudiko Imanol-ena baino luzexeagoa, hala ere. Ez da pausarik izen abizenen artean, oinarrizko maiztasun kurbaren jarraipenak begi bistan aditzera ematen duen eran. Baina nabarmen da, floRENtino izenaren nukleotik beheranzko isatsa, berriro abiatzen dela gorantz GOIburu abizenaren silaba azentudunaren gailurrerantz, nahiz gailur hau nahikoa apalagoa izan aurrekoa baino (baina nabarmenagoa, 2 irudiko laRRAñaga-rena baino). ${ }^{44}$ Entzukeran sentitzen da GOIburu-ren nolabaiteko gailurra, floRENtino izenarenaz gain.

Zein da esaldion egitura informatiboa? Unitate bakarrean emanda, zalantzarik ez, predikazio gune bana osatzen dute ( 2 irud.). Bi unitatetan emanda, berriz, lehena ezin izan da predikazio marko baino, bigarrena predikazio gune. Eta azken honen barne aurkituko dugu, bi osagairekin, hierarkia semantiko prosodikoa unitate hasierako osagai haren alde (4.).

\subsection{INTONAZIO UNITATEEN ARBITRARIOTASUNAZ}

Intonazio unitateen luzera mugatzen baldin badute giza gaitasun mnemoteknikoak eta lan-memoria gaitasunak, ez da legerik, hiztunari eragotziko dionik, unitatea komeni bezain labur emateko. Zenbaitetan hiztunak, hala nahita, esaldiko osagai lexiko bakoitza eman lezake unitate independente batean (aditza bera ere 
bai, nahi izanez gero). Are moztu lezake erditik hitz bat bi intonazio unitatetan, silaba edo fonema jakin bat bereziki azpimarratzeko (nola egiten den, ahoskera zuzendu nahian, Ö). Intonazio unitateen ebakerak eragin lezake inoiz euskaraz aditzaren aurreko osagai fokalizatua eta aditzaren arteko etena ere. Hala, esateko, Zaratamoko 86 urteko Pedro Olabarrieta Ormaetxe jaun agureak egin aurkezpenean :

\section{(28) Pedro / Olabarrieta / Ormaetxe / naiz. (Zaratamo - G86) (ik. 7 irudia)}

Esaldiak 4.366,44 ms-ko iraupena du, nahiz 12 silaba baino ez dituen. Hitz bakoitza ematen da intonazio unitate beregain batean ${ }^{45}$ (are aditza bera ere), unitate artean pausa isil ikaragarriak eginez (800, 600 eta 450 ms-koak ). Lehen hiru unitateek goranzko intonazioz amaitzen dute azken silaba, bitan tonua nahikoa altuagoa izaki nukleokoa baino. Soilik azken unitatea, askoz gailur apalagokoa izateaz gain, ${ }^{46}$ amaitzen da beherakada nabarmen batean, predikazioaren amaiera iragarriz. Lehenengo hiru unitateak, informatiboki, ezin izan dira predikazio markoak baino, eta soilik azkena predikazio gune (PM + PM + PM + PG).

Ez da hau corpusean esaldi bakarra izen fokalizatua eta aditzaren artean unitateen arteko muga erakusten duena. Hala moduzkoak dira segidakoak ere :

(29) a. Pedro / Maurtua / nas, Atxondoko / alkatea. (Atxondo - G) (ik. 16 irud.)

b. Enrike / Axpe / nas / eta / Aramaixon, e, jaixotakue, Ö (Aramaio - G)

c. (Ni) / Nati / Telletxea / Juanena / naiz, emen / erri ontan jaiua, Urrozen, eta baserri artan / jaiua. (Urroz - E) (ik. 20 irud.)

\section{Izena (Izen-abizenak) + NAIZ + NI (edo beste osagai laburren bat)}

31 esaldi ditugu corpusean Izena (Izen-abizenak) + Aditza + Osagaiak egitura erakusten dutenak. Horietako $2 \mathrm{k}$, soilikni izenorde pertsonala dute aditzaren ondoren. Atal honetan aztertuko ditugu. Beste 29ek osagai luzeagoak edo/eta gehiago dituzte aditz ondorean, eta 7. atalean aipatuko ditugu. Segidakoak, $n i$ izenordea aditz ondoretik ematen duten bi esaldiak :

(30) a. Ibon nauk ni, Ö (Azkoitia - M) (ik. 8 irud.)

b. (Ba,) Pabi / Astondoa nas ni, Ô (Arratia - G40) (ik. 9 irud.)

Azkoitikoak $535 \mathrm{~ms}$-ko iraupena du (4 sil.). Arratikoak, $843 \mathrm{~ms}$ eta 8 silaba. Azkoitikoa intonazio unitate bakarrean ematen da. Arratikoa seguru asko bitan : Pabi izena bere kasakoan ; eta Astondoa nas ni hiru osagaiak zalantza gabeko unitate bakarrean. ${ }^{47}$

Bi esaldiek erakusten dute gailur intonatibo-prosodiko-predikatiboa intonazio unitatearen aurreko osagaian emana, euskaraz ohikoa dirudien legean. Batek Ibonen lehen silaban, besteak asTONdoa-ren bigarrenean. Hortik aurrera, intonazio unitatearen isats intonatiboa beherantz, isatsean gailurreko osagaiaren nukleo ondoko silabak + aditza + ni osagarria besarkatuz. Bi kasuetan, nolanahi, intonazio unitateko azken silabak (ni osagaia kasuan, ez aditza) muga intonazio propioa $\mathrm{du}$, oso goranzko joeraz. Garrantzizko ez dela inolako etenik ematen aditza eta ondoko izenordearen artean, eta hau, entzukeran ere, batere gailur prosodikorik gabe ematen da unitate isatsean. 
Zein da halako esaldien egitura informatiboa? Hiru osagaiak (osagai fokalizatua + aditza $+n i$ izenordea) unitate bakarrean emanak, zalantzarik gabeko predikazio gune dira $(\mathrm{pg}){ }^{48}$ eta hiztunak, informatiboki, hauen deskodetzea ere bloke batean egingo du. Ordea, esan nahi ote du horrek hierarkia predikatibo berdina dutela hiru osagaiek ? Ez, noski.

Intonazio unitatearen barne, bada zalantza gabeko hierarkia intonatibo-prosodikoa, osagaiak $1>2>3$ eskalan sailkatzen dituena gailurretik isats intonatibo-prosodiko predikatiboaren azken muturreraino :

(30) Ibon $>$ nauk $>$ ni.

Eta bada, gainera, osagaien arteko hierarkia semantikorik ere. Aipatu dugu (4.), testu-aurre horretan, izen espezifikatzaileak informazio kopuru handiagoa eskaintzen duela aditz generikoagoak baino. ni izenordea, bestalde, naiz aditz pertsonalaren ondoretik emana, erabat iragargarria gertatzen da. Hierarkia semantikoa, beraz, (30)eko bera : $1>2>3$.

\subsection{Hierarkia semantikoen inguru}

Baina gailurra unitate hasieran izateak ez du esan nahi isatseko edo aditz ondoko osagaiek, garrantzia predikatiborik ez dutenik, (30)eko ni erabat iragargarriaren kasuan bezala. Izan litezke hauek ere berri eta esanahitsu, nahiz hiztunak zeinahi arrazoirengatik gailentasunik ez ematea erabaki. Gailurreko osagaiaren mende sentituko dira beti. Baina ez horregatik zahar, ezagun, tema, mintzagai, edo dena delako. Argiago, adibide batekin. Eman dezagun aditzaren ondoko osagaia $n i$ izan ordez, $o(r)$ ain edo hemen bezalako aditzondoak direla :

(31) a. Ibon nauk oain

b. Ibon nauk hemen

Erraz suma liteke intonazio unitate bakarraren isats amaierako aditzondo horien garrantzia ( $n i$-ren aldean), segidakoak bezalako testu-ondo batzuen aurretik :

(32) a Ibon nauk oain, izena aldatu eta gero ; lehen Juan niñuan.

b Ibon nauk hemen, baina etxean Juan esaten zidatek oraindik.

Nabarmen da hiru osagaien garrantzia semantikoa (nahiz aditz generikoak agian txikiagoa izan beste bi osagai espezifikatzaileek baino). Unitate bakarrean, hirurak lirateke maila berean berri. Mezu hartzaileak denak multzo bezala deskodifikatuko ditu informatiboki. Hala ere, (31)ko esaldiek badute bere ohiko hierarkia prosodiko intonatiboa, eta beraz predikatiboa, hasierako osagaiaren alde. (33)ko esaldiek, ordena aldatuta, (31)koen hierarkia semantiko eta informatiboa bera dute, eta oso antzekoak dira, teoria kanoniko azkue-altubetarrak dioenaz bestela. Beren arteko alde bakarra prosodiko intonatiboa da, hiztunak gailur prosodiko-intonatiboa izenari eman ordez, aditzondoari eskaintzea erabaki duelako :

(33) a. Oain nauk Ibon

b. Hemen nauk Ibon 
Baina (32)ko testuinguruan aldagarriak dira (31)koekin, komunikazio orokorraren alde edo kalte handirik gabe :

(34) a. Oain nauk Ibon, izena aldatu eta gero ; lehen Juan niñuan.

b. Hemen nauk Ibon, baina etxean Juan esaten zidatek oraindik.

Adibide gehiagok ere erakuts lezake, nola, intonazio unitate bakarrean emandako esaldi laburren ordena aldaketen eragina ez den absolutua. Eman dezagun, Ibon eta Jonen bila etorri nauk esaldiarekin aurkezten den pertsona. Ibonen arreba Leirek ez du eragozpenik izango (35a) edo (35b) ordenetako esaldiekin erantzuteko, bietan ere hasierako osagaia azpimarratuz :

(35) $\mathrm{x}$. Ibon eta Jonen bila etorri nauk.

a. Ni nauk Leire, Ibonen arreba. Ze nahi duk? // [NI nauk Leire]

b. Leire nauk ni, Ibonen arreba. Ze nahi duk? // [Leire nauk ni]

Ordenamenduaren subjektibotasuna mila bider handiago da gaurko kanonak iradoki baino.

\subsection{ISATS INTONATIBO-PREDIKATIBO BATEN LUZERAZ}

Zenbat osagai eman litezke unitate baten isats intonatibo-prosodiko-predikatiboan? Ez nahi adina. Eman ahal izanen dira' intonazio unitatearen mugetan sar litezkeen beste : denera 10 silaba ; 15 asko luzatuz ; nahiz esaldi amaierako isats deazentuatuak diren, seguru asko, intonazio unitateak errazen luza litzaketenak. Eman dezagun antzezpen bateko aktore rol anitzeko batek egiten dituela segidako esaldiak, jokatzen dituen pertsonaiak aipatuz :

(36) a. Blanka nauk hasieran ( 7 silaba)

b. Eleonor bihurtzen nauk bigarren eszenan (14 silaba)

c. Eta Rosamunda bilakatzen nauk azken aurreko hiru eszenetan bukatzeko (26 sil.)

Lehen esaldia aisa eman lezake intonazio unitate bakarrean : [BLANKA nauk hasieran]. Nekez bigarrena ; errazen, bi unitate ahoskatuz : [ELEONOR bihurtzen nauk] [BIGARREN eszenan], nahiz inoiz luza litekeen lehen unitateko isatsa beste 6 silabaz. Hirugarren esaldia, nahita ere, ezingo du intonazio unitate bakarrean eman (22 silabako isats intonatiboz).

\subsection{BI GALDERA GARRANIZIZKO}

1. Zer balio informatibo dute esaldiko predikazio gunearen ondoko intonazio unitateek ? Zer dira ? Predikazio gune ? Predikazio marko? Eztabaida 7. atalean.

2. Zer gertatzen da, ni bezalako osagai labur bat ematen denean, aditz aurreko osagai fokalizatuaren aurretik? Zer balio informatibo du ? 8. atalean eztabaida.

\subsection{Antzeko adibide bat corpusean}

Bada corpusean, atal honetan aztertzen etorri garen (30)eko 2 esaldien antzeko beste bat. (37a) esaldiak ere intonazio unitate bakarrean ematen du aditz aurreko osagai fokalizatua, aditza eta honen ondoko osagaia ere, (37b) itxuran intonatua : 
(37) a. (Bueno,) ni(r)i Lurdes gasta isena, Ö (Ondarru - N28) (ik. 32 irud. $)^{49}$ b. (Bueno,) [NI(R)I] [LURDES gasta isena]

\section{Izena (Izen-abizenak) + NAIZ + hainbat osagai luze, egitura}

Corpusean 29 esaldi ditugu era honetakoak (beste 19 ere bai, aditzaren aurreko osagaiaren aurretik besteren bat erakusten dutenak, 8. atalekoen artekoak). Hauen itxurako :

(38) a. Inaxio / Martiarena nauk, zarauztarra, ... (Zarautz - G) (ik. 10 irud.) b. Elena naiz, hemengoa, Zugarramurdikoa, ... (Zugarramurdi - N) (ik. 11 irud.)

c. Daniela Bernaola naiz, da Orozkon jaioa. (Barandio - E) (ik. 12 irud.)

d. Begoña Alegria naiz, Busturiko (/) alkatesa. (Busturia - E) (ik. 13 irud.) e. Pedro Erbiti naiz, Periko, ta Beuntzen jaioa, t' alde hontan bizi naizena. (Beuntze - G) (ik. 14 irud.).

f. Rosa Mari / Ostogain naiz, Berrizko / alkatesa. (Berriz - E) (ik. 15 irud.) g. Pedro / Maurtua / nas, Atxondoko / alkatea. (Atxondo) (ik. 16 irud.)

Badira aditzaren intonazio unitatearen ondoretik unitate bat baino gehiago erakusten duten esaldiak. Unitate hauetako batzuk eta juntagailu bidez ere ematen dira (ik 38d, f). Zenbaitetan aditzaren ondoretik emaniko osagaiak -ko izenlagun nominalizatuak dira (38c), edota izenaren ondoan emaniko erlatibozko esaldi jokatu edo jokatugabe nominalizatuak (38f) beren osagarri propioak dituztenak. Nolanahi, aditz ondoko unitateen barietatea (38)ko esaldiek erakusten dutena baino ugariagoa da. ${ }^{50}$

Badira corpusean alderantzizko bi egitura, izena eman ordez aditz aurre justuan, kargua ematen dutenak, eta izena, aditz ondorean : Kargua + Aditza + IzenAbizenak. (38)koen egitura intonatibo bera erakutsiko dute :

(39) a. Berangoko alkatea nas, JoÖ, Jose Antonio Landa. (Berango - G) (ik. 17 irud.)

b. Leitzako alkatea naiz, Juan Oronoz, ... (Leitza - G)

Esaldi guztion lehen atalak (Izena (edo) + Aditza), 4. eta 5. ataletan aztertu esaldien egitura eta ezaugarri berak erakusten dituzte. Zalantzarik gabeko predikazio gune $(\mathrm{PG}),{ }^{51}$ intonazio / informazio unitate beregainak, esaldia hor bukatuta ere mezu hartzailea ase utz lezaketenak. Gailur intonatibo-prosodiko-predikatiboa unitateko lehen osagaian izanen dute, eta aditza honen isats gisa emana.

Arazoa, ondorengo osagaiak dira. Zer kategoria informatibo dute? Topiko ? Mintzagai ? Antitopiko ? Afterthoughtak, geroko burutazioak? Halako kategoriak eman ohi zaizkie beste hizkuntzetan ere, esaldian predikazio gune baten ondorean ager litezkeen osagarriei. Guk beste ikuspegi bat azalduko dugu hemen. ${ }^{52}$

\subsection{ZeNBAIT EZAUGARRI PROSODIKO}

Predikazio gunearen ondorengo osagaiek ezin hobeto mugatutako intonazio unitate beregainak osatzen dituzte. Corpuseko 48 esalditik $44 k(\% 91,7)$ du pausa 
bat naiz aditzaren ondoren. ${ }^{53} 39$ pausa isilak dira $(\% 88,6)$ eta 5 bete $(\% 11,4$; ik. $47 \mathrm{~b} ; 58 \mathrm{i}, \mathrm{q}) .48$ esalditik $47 \mathrm{k}(\% 97,9)$ erakusten du naiz (edo kideko) aditzaren ezohiko luzapena (ik. 11-17 irud.). Astondoa nas ni esaldian tarteko nas « luzatu gabeak »150ms-ko iraupena du; Ibon nauk ni esaldiko nauk-ek 125 ms. 48 esalditan naiz aditzak bakar batean du $200 \mathrm{~ms}$ azpitiko luzera $(175 \mathrm{~ms}) .{ }^{54} 6$ esalditan 200-249 ms bitarteko iraupena ; 8tan 250-299 ms bitartekoa ; 22tan 300-399 ms bitartekoa ; eta 11 tan 400 ms baino luzeagoa. 48 esalditako 41 ek $(\% 85,4)$ erakusten du naiz aditzaren ohikoa baino $100 \mathrm{~ms}$ edo gehiagoko iraupen aldea, eta $33 \mathrm{k}$ $(\% 68,7)$ ohikoaren bikoitza edo gehiago. Esaldi guztiek (48) erakusten dituzte intonazio gailur propioak aditzaren unitatean eta ondorengoan (ik. 10-17 irud.). Esaldi guztiek erakusten dute, gainera, gailur propioarenaz gain, beste eten seinaleren bat (pausa edo luzapen).

\subsection{Predikazio gune berRiak lehen predikazio gunearen ondoren}

Intonazio / informazio unitate beregainak izanik, hauei dagozkien kategoria informatiboak izanen dituzte. Daniela Bernaola naiz/da Orozkon jaioa (38c) esaldiaren bigarren unitatea, zalantza gabeko predikazio gune berria izango da (PG), eta berau jasotzean mezu hartzailea bigarren aldiz sentituko da ase, esaldiaren predikazioa berriro osotasunean jasoa balu bezala. Esaldia zalantza gabe amai liteke bertan eta hala amaitzen da. Esaldiak bi predikazio gune ditu. Bi gauza predikatzen ditu : 1. lehenik, hiztuna, Daniela Bernaola dela ; eta 2. Orozkon jaioa dela. ${ }^{5 s}$ Ez du esanahi bi esaldiren aurrean gaudenik. Mezu hartzaileak bigarren predikazio gunea jasoko du, lehena deskodetu, prozesatu eta ulertu eta gero (eta mezua bere memoriako beste apalen batera eramanda, lan memoria libre utziz predikazio berriak jasotzeko). Bigarren predikazio gunea jasotzen duenerako lehenak testu-aurre rola jokatuko du, amaieran goranzko intonazio erakutsiz predikazioaren jarraipenaren iragarle. Bigarren unitateko azken silabaren intonazioa beheranzkoa da, esaldiaren eta predikazioaren amaiera iragarriz. Nabarmena da bigarren unitateko gailurraren apala lehenaren aldean (deklinazioa). ${ }^{56}$

(38b) esaldiak, Elena naiz, emengoa, Zugarramurdikoa, Ö (11 irud.), bi predikazio gune ditu lehenaren ondoren. Honek, hiztuna, Elena dela predikatzen du eta amaierako silabak goranzko muga intonazio nabarmena du. Bigarren predikazio guneak, hiztuna, bertakoa dela predikatzen du, eta berriro amaitzen da goranzko intonazioz, jarraipena iragarriz. Azken unitateak, hiztuna, Zugarramurdikoa dela predikatzen du, eta nahiz esaldia bertan bukatzen den (gero beste esaldi oso bat dator), goranzko intonazioz amaitzen da hau ere. Ez da deklinaziorik sumatzen hiru nukleoetako gailurren artean, ezpada igoera hirugarrenean.

13 irudiko Begoña Alegria naiz, Busturiko (/) alkatesa. esaldiaren inguruan beste hainbeste esan liteke. Lehen unitateko nukleoko silaba ikaragarri igotzen da, isatsean zehar jausteko (nahiz abizenak baduen azentuazio lexiko ahula). Unitateko azken silaba gorantz predikazioaren jarraipena iragarriz. Bigarren unitateko bigarren silabak gailur apalagoa du (deklinazioa), eta beharbada egin liteke zalantza unitate bakar edo biren aurrean gauden (Busturiko-ren azken silabak ere goi tonua duelarik, eta alKAte-ren bigarrena zertxobait igotzen delarik. Unitatea beheranzko intonazioz amaitzen da. 
14 irudiko esaldian, berriz, 5 unitatetatik, soilik erdiko ta-k eta amaierakoak dituzte gailur apalak. Beste hirurak maila bertsukoak dira. Esaldiak 4 predikazio gune ditu (lau "galdegai", nahi izanez gero). Antzeko hausnarketak egin litezke 15, 16 eta $17 \mathrm{ko}$ esaldien inguruan.

\subsection{LEHEN PREDIKAZIO GUNEA BEHERAKO INTONAZIOZ AMAITZEN DUTEN ESALDIAK}

Aipatu esaldi guztiek erakusten dute goi tonua unitate amaiera guztietan, salbu azkenean. Ez da, nolanahi, beti hala gertatzen. Aurki genezake inoiz beheranzko intonazioa () aditzaren ondoren (edo beste unitate baten amaieran), nahiz esaldiak jarraipena izan beste osagarri batzuekin. Hori gertatzen da, esateko, segidako esaldien kasuan aditz ondorenean :

(40) a. Joxe Zinkunegi naiz(), azken beatzi / urte t' erdian / Errezilgo alkatea. (Errezil - G) (ik. 18 irud.)

b. (Ni) / Jose Antonio / Gorostiola nas(), Derion / jaiokoa, oiñ, e, berrogei urte, setienbrian / milla / ta bederatzireun / ta berrogeta / amaikan.

(Derio - G40) (ik. 19 irud.)

c. (Ni) / Nati / Telletxea / Juanena / naiz(), emen, erri ontan jaiua, Urrozen, eta baserri artan / jaiua. (Urroz - E) (ik. 20 irud.)

\subsection{Predikazio gune baten ondoko unitate guztiak predikazio gune ?}

Predikazio gune bat baino gehiago duten esaldion aurrean, galdera egin behar da, ea lehen predikazio gunearen ondotiko beste intonazio / informazio unitate guztiak ote diren derrigor predikazio gune. Erantzuna, ezezkoa da. Zenbaitetan aurkituko baititugu artean ondorengo predikazio guneen markoa baino ez diren unitateak, eta zeinen ondoren esaldia ezin litekeen amaitua sentitu, ez hiztuna ase. Hala gertatzen da (40a)ko azken beatzi edo urte t'erdian unitateen ondoren. Edota (40b)ko Derion/oiñ /e /milla/ta bederatzireun edo ta berrogeita unitateak jasota. Ezin hor esaldia amaituta sentitu. Berdin (40c)n emen edo eta baserri artan-en ondoren. Beste hainbeste segidako esaldietan ere, kurtsibaz ematen ditugun unitateekin :

(41) a. Enrike / Axpe / nas / eta Aramaixon, e, jaixotakue, ... (Aramaio - G) b. Julian (/) Zubeldia naun, Lizartzakoa, orain dala / berrogeita bederatzi urte (?) / jaioa, ... (Lizartza - G49)

c. Jose Antonio / Rekondo naiz, iazko / ekaina ezkerotik / Ernaniko / alkate / naizena. (Hernani - G)

\section{5. -ko IZENLAGUNAK UNITATE BEREGAINETAN ?}

Alkateek beren buruen aurkezpenerako egiten dituzten esaldien artean sail bat dira izen-abizenen eta aditzaren ondoretik kontatzen dutenak zein herritako alkate diren. Kuriosoa da, esaldiotako askotan, herri izenak, -ko atzizkiz, unitate independentea osatzen dutela ondoko alkate hitzarekiko, nahiz biak sintaktikoki hertsiki lotuak izan. ${ }^{57} \mathrm{Hala}$, esateko, goiko $(38 \mathrm{f}, \mathrm{g})$ esaldietan. Baita segidakoetan ere ((42c)n bi bider) : 
(42) a. Mikel Zabala naiz, Astigarrako / alkatia. (Astigarraga - G)

b. (E,) Luis $(/$ ) Galarraga naiz, Bidegoiango / alkatea, ... (Bidegoien - G)

a. Beñat Abeberri naiz, Arbonako / akalÖtia, alkatea, ah, Lapurdiko / probentzian. (Arbona-G)

d. Loren Arkotxa naiz, Ondarruko / alkatea. (Ondarru - G)

e. Xabier (/) Portugal naiz, Pasaiako / alkatea. (Pasaia - G)

Batzuetan zalantza egin liteke bi unitate diren edo bakarra. Hala (38d)n, edo segidakoan :

(43) Bitoriano Gallastegi naiz, Bergarako (/) alkatea. (Bergara)

Beste batzuetan, berriz, unitate hasierako izenlagunak hartzen du unitate bakarreko gailurra eta kargua isats intonatiboan ematen da ahuldua. Hala (39a, b ; 40a)n edo segidakoetan :

(44) a. (E Ö,) Juan Karlos (/) Zuloaga naiz, Aiako alkatea. (Aia - G)

b. (Bueno,) Iñaki Lete naiz, Antzuolako alkatia, ... (Antzuola - G)

c. (E,) Pili / Ardanza nas, Durangoko alkatesa, ... (Durango - E)

d. Jose Ramon (/) Olazar naiz, Errigoitiko alkatea. (Errigoiti - G)

e. Karmentxu (/) Etxeberria naiz, Segurako alkatea. (Segura - E)

\subsection{ESALDI ATALAK FOKALIZATZEKO BIDE}

Komunikazioaren lege unibertsala da, esaldi atalen bat bereziki azpimarratu nahi izanez gero, berau bakarrik ematea intonazio / informazio unitate beregain batean ; edota, gutxieneko, unitate horren gailur prosodiko predikatiboan, aurreko unitatearen isats intonatibotik aterata (edo ondorengoaren buru aurre ahuletik AO itxurako hizkuntzatan). Esateko, goiko (30)eko esaldi bietan (Ibon naukni; Astondoa nauk ni), nahikoa litzateke ni izenordea unitatearen isats intonatibotik ateratzea eta unitate beregain batean ematea, berau bereziki azpimarratua gertatzeko predikazio gune berezi bezala :

(45) a. Ibon nauk / ni.

b. Astondoa nas / ni

(46) a. [IBON nauk] [ni]

b. [ASTONDOA nas] [ni]

Halako esaldi batek beste segida batean pentsarazteko bide ematen du : Ibon nauk / ni. Beste hauek, berriz, ez dakit. edo antzeko zerbait, segida benetan ematen den inporta gabe.

\subsection{BADA PREDIKAZIO GUNEeN ARTEKo MIERARKIA PREDIKATIBORIK ?}

Predikazio gune bat baino gehiago duten esaldien artean, galde liteke ba ote den hauen artean nolabaiteko hierarkia predikatiborik, batzuk besteak baino garrantzi gehiagokoak izan ote litezkeen, eta hori nolerebait islatzen ote den nonbait.

Erraxkeria bat esanez, esan, ondoko unitateak beti direla aurrekoak baino berriagoak, hau da, aurrekoen jakinaren gainean predikatzen direnak, hauek testu- 
aurre bezala erabiliz. Kirtenkeria dirudien horrek badu berezko balio psikolinguistikoa, azkena esana geratzen baita beti azken, berrien, mezu hartzailearen prozesatze bideetan, memoria laburrean, lan memorian, aurrekoei lekua ebatsiz. Erretorika klasikoak aipatu du antzinatik fenomenoa.

Printzipio orokor horrezaz landa, gure ustea da, hiztunak subjektiboki, beti enfatiza lezakeela modu berezian, edo ahuldu nahitara, zeinahi predikazio gune besteen gainetik edo azpitik, honi apropos eskainiz ahots indar handiagoa edo ahulagoa, iraupen luze edo laburragoa eskainiz unitateko atalei, edo unitateei intonazio gailur garaiago edo baxuagoa (eta kontuan hartuz, unitateen arteko deklinazio prozesuak, gerta liteke ondoko unitateak ematea aurrekoak baino indartuago, tonua baxuagoa izanda ere). Hala, esateko, 14 irudiko esaldian, non, bigarren unitateko Periko, edota laugarrengo BEUNTZEN jaioa bereziki azpimarratuak gerta litezkeen hasierakoaren aldean. Ez hala hirugarren unitateko ta edo amaierakoa, zeinak, gailur baxuagoa izateaz gain, beherakada intonatibo nabarmena duten, eta indar gutxiagoz emana diruditen uzten duten arrastoaren ahulagoak adieraz lezakeen moduan.

Eztabaida, nolanahi, antzu samarra da. Bi predikazio guneren arteko garrantzi predikatiboz eztabaidatzea, bi esaldi nagusiren arteko garrantzi predikatiboaz eztabaidatzea bezalaxe da. Eztabaida liteke, eta are ondorioetara iritsi. Baina hierarkia baino askoz garrantzitsuagoa da, konturatzea, bi predikazioren aurrean gaudela. Garrantzitsuago ote da Elena izatea, Zugarramurdikoa izatea baino, edo Zugarramurdikoa izatea, Elena izatea baino.

\subsection{CoRpuseko beste esaldiak}

Sail honetako esaldi orain arte aipatu gabeak dira segidakoak ere :

(47) a. Agustin (/) Laskurain naiz, bilabonatarra, ... (Bilabona - G )

b. Jose Angel / Bilbao nas, eta hemen, Goierriko, ... (Goierri (B) - G)

c. (E,) Antton Amunarriz nauk, e, hemen, Larraulkua, ... (Larraul - G)

d. (Bueno,) Mari nas, Mari (/) Alzorrozaga, ... (Sopela - E40)

e. Antonio (/) Ieregi naiz, Arbizuko alkatea, erri txiki bat, Nafarroan dagona, Ö (Arbizu - G)

\subsection{AdITZ AURRERATUKO JOSKERA}

Sail honetan aipatu ditugun esaldi guztien ezaugarria da, hiztunak ez duela inoiz ere esaldiko aditza eta lehen predikazio gunea, gehiegi atzeratzen esaldian. Mezu hartzailea laster senti liteke ase esaldian. Lehen predikazioa jaso, hau prozesatu, eta behar izanez gero ondoren besteren bat jasotzeko aukeran. Zer gertatzen da, predikazio berak egiteko, hiztunak esaldian aditza erabat atzeratuko balu? Predikazio gune bakarra izango dugu esaldian, aditza daraman azken intonazio / informazio unitatearekin. Bitartean predikazio markoak baino ez ditugu izango ; benetan zailak, luzeegiak, bere horretan lan memorian gordetzeko predikazio gunea iritsi bitartean. Halako itxura bitxia har lezakete goiko esaldiek aditza atzeratuz gero : 
(48) a. Beuntzen jaio eta alde hontan bizi naizen Periko, Pedro Erbiti naiz.

b. Orain dala berrogeita bederatzi urte jaiotako Lizartzako Julian Zubeldia naun, ...

c. Arbizu, Nafarroan dagon erri txiki bateko alkate, Antonio Ieregi naiz.

d. Jose Zinkunegi, azken beatzi urte t' erdian Errezilgo alkatea naiz.

e. Jose Antonio Rekondo, iazko ekaina ezkerotik Ernaniko alkate naizena naiz.

Hala moduzko esaldiek, ez horren ezohikoak gaur egun, ulermen arazoak eragiten dituzte aditza atzeratzearen kariaz.

\section{NI (edo) + Izena (edo) + NAIZ (edo) + (hainbat osagai), egiturak}

${ }^{58} \mathrm{Atal}$ honetan aipatuko ditugu aditzaren aurreko osagarri fokalizatuaren aurretik beste osagarri bat erakusten duten esaldiak, bereziki aztertzeagatik lehen osagai honen jokaera. 50 esaldi ditugu, hiru egitura mota nagusitako.

Batetik, sail nagusian, lehen osagai ni izenorde pertsonala erakusten duten 41 esaldiak. 22 aditzarekin amaituko dira, eta $19 \mathrm{k}$ zenbait osagai erakutsiko dituzte artean ondoretik, 7. atalean aztertu moduan. Era honetako esaldiak (beste guztiak (57) eta (58)n) :

(49) a. (Bueno, ba,) ni / Migel Angel naiz, ... (Uharte - G) (ik. 21 irud.) b. Ni / Erramun niz, Luzaideko (/) mutil bat, ... (Luzaide - G) (ik. 22 irud.) c. (Bueno,) ni, e, Xabier (/) Iturbe naiz, ... (Lekeitio - M29) (ik.23 irud.) d. $\mathrm{Ni} /$ Elisa nas, ... (Busturia - E60) (ik. 24 irud.) e. Ni / Maribel nas, ... (Dima - E) (ik. 25 irud.)

Sail berean aztertu ditugu, ezaugarri bertsuak dituztelakoan, $d a$ adizkiaren aurreko izen osagarriaren aurretik, nire izena osagarria erakusten duten 6 esaldiak (bakarrak du beste osagarriren bat aditzaren ondoretik). Segidakoaren antzekoak (ik. beste bostak (59)n) :

(50) (Bueno,) nire isena Itziar da, ... (Ondarru - N27) (ik. 26 irud.)

Azkenik, sail honetan aztertu ditugu, naiz aditzaren aurrean beste osagarri fokalizaturen bat emanda, izena edo izen-abizenak honen aurretik erakusten dituzten 3 esaldiak, segidakoaren itxurakoak (ik. beste biak (60)n) :

(51) Rejina, Orbarakoa niz, ... (Orbara - N - E) (ik. 27 irud.)

\subsection{NI (EDO) LEHEN OSAGARRIAREN EZAUGARRI PROSODIKOEZ}

Aztertu 50 esaldietan ematen da lehen osagaia (ni edo) intonazio unitate beregain batean. 18 esaldik (\%36) pausa nabarmena du osagai fokalizatua eta honen aurrekoaren artean. 15 pausa isilak dira (\%83,3) (ik. 21, 22 edota 27 irud.), eta 3 soilik beteak (\%16,7) (ik. 23 irud.). Baina, lehen unitateko azken bokalaren (i, a, u) ezohiko luzapena aurkituko dugu nabarmen -bikoitza baino luzeagoa- 50etako 41 esalditan (\%82,0) (ik. $24-27$ irud.). Soilik 9 esaldik ez du luzapen nabarmenik erakusten (eta hauetako bakarrak erakusten du, $80 \mathrm{~ms}$-ko bokal ez oso luze baten 
ondoren, $30 \mathrm{~ms}$-ko pausa isila). 11 esaldik $100-149 \mathrm{~ms}$, 9k 150-199 ms, 8k 200$249 \mathrm{~ms}$, eta $13 \mathrm{k} 250 \mathrm{~ms}$ baino gehiagoko iraupena dute. Esaldi guztiek (50) erakusten dute intonazio gailur propio bana aditz aurreko bi osagarrietan. Esaldien $\% 84,0 \mathrm{k}$ seinale nabarmena erakusten du intonazio gailurraz gain.

Segidakoak, lehen osagaian intonazio unitate propioa identifikatzeko arazoa duten 3 esaldi :

(52) a. Ni / Marije naiz. (Oñati - E33) (ik. 28 irud.)

b. Ni / Martxeli Sagastume naiz, alegritarra, ... (Alegia - N) (ik. 29 irud.)

c. (Bueno, ba,) ni / Juan Mari nas, Abadinokue, ... (Abadino - MG) (ik. 30 irud.)

(52a) esaldiko $n i$-ren bokalak ( 28 irud.) ez du $75 \mathrm{~ms}$-ko iraupena baino. Nabarmen da, hala ere, honen amaierako igoera, nola ondoko unitateko lehen silabako amiltzea, berriro bigarren silaban igotzeko unitateko gailurrerantz. Amiltze berriaren ondoren, amaiera silaban ez da beste zenbaitetan bezalako igoera ikaragarririk sumatzen, nahiz zerbait baden. ( $52 \mathrm{~b}$ )ko $n i$-ren bokalak ( 29 irud.) $55 \mathrm{~ms}$ ko iraupena du. Hala ere, aurrekoan bezala, txapel intonatibo propioa suma zaio nabari, ondoko unitateari suma zaion moduan. (52c)ko esaldia da 50etan bitxiena. ni-ren bokalaren iraupena $75 \mathrm{~ms}$ ingurukoa da, baina apenas tontor intonatibo nabarmenik erakusten duen, nahiz ondoko unitateak bai duen bere propioa. ${ }^{59}$

Unitate bien arteko gailurren erlazioa ez da batere garbia. Zenbaitetan lehen osagaiak du amaieran esaldi osoko intonazio gailurrik garaiena, batzuetan alde handiz eta besteetan txikiz (ik. 22, 24, 25 edo 27 irud.). Bestetan, altura bertsuko gailurrak dituzte bi unitateek (21, 23, 28 irud.). Eta badira esaldiak, bigarren gailurra garaiagoa dutenak lehena baino (ik. 26, 29 edo 30 irud.). Ez da beraz garbi deklinazio ezaugarri unibertsalik. Bestelakoan, batzuetan amiltze nabarmena da lehen unitatetik bigarrenera $(21,24,25,27(?), 28,29$ irud.). Bestetan ez da halako jausi aldi nabarmenegirik bi unitateen arteko trantsizioan (21, 23, 26, 27 (?) irud.). Beharbada, euskalkietako azentuazio eta intonazio eredu desberdinen eraginez.

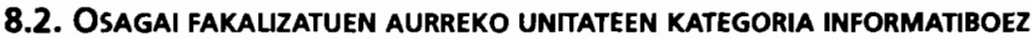

Osagai fokalizatuaren aurreko osagaiak/ek, beti, intonazio unitate beregain bat osatuko badute, hauen balio informatiboa ezin izan da predikazio markoarena baino. Berori jasota mezu hartzailea ezin inola gera liteke ase, ezta ere esaldia bertan bukatu. Beti izanen dira mintzagai. Esaldion azterketatik abiatuta, eta gure euskal esperientzia orokorrari begira, hipotesi zenbait aurrera genezake :

1. Euskaraz osagai bat bereziki fokalizatu nahi denean, honek hartuko du, beti, berak sortuko duen intonazio unitatearen gailurra, eta honen hasieran emango da.

2. Artean hiztunak esaldian aditza eman gabea badu, eta agertzekoa bada, fokalizatutako osagai horri erantsiko zaio intonazio unitate bereko isats intonatibo-prosodiko-predikatibo bezala (salbuespenen batekin; ik. 5.1.), eta beharbada beste osagai laburren bat ere unitate berean arrastatuz ondoretik enklitikoki (gogoratu (30a, b)). 
3. Osagai fokalizatua duen unitatearen aurreko osagaiak/ek, beti, intonazio / informazio unitate beregain bat osatuko du/te, inola irabazi gabe fokalizazioaren gailentasuna. ${ }^{60}$

Euskaraz osagai fokalizatuak beti du bere gailur intonatibo-prosodiko-predikatibo propioa. Honen aurretik hasitako unitate batek ere bai, euskaraz unitateek hasieran bide dutelako beti beren gailurra. Hala, beti aurkituko ditugu bi gailur, eta mezu hartzaileak beti prozesatuko du lehen osagaia unitate independente bezala, ondoko unitatea / gailurra jaso aurretik. Hizketa naturalean, nolanahi, maizenik indartuko da unitateen arteko muga bestelako seinaleekin (pausa, azken silaben luzatze) gure corpusean bezalatsu. ${ }^{61}$

Desberdin izango da, hala ere, egoera, aditzaren intonazio / informazio unitatea predikazio gune ez bada, eta beraz, honen aurreko osagaia bereziki fokalizatua gabea. Azkue-Altuberen galdegai lege kanonikoaren kontrara eratutako esaldiez ari gara (euskarazko esaldien bi herenez). Hauetan' aurki litezke bi osagai aditzaren aurretik emanak intonazio unitate berean. Unitateko gailurra ez du bereganatuko aditz aurreko osagaiak, baizik eta unitate hasierakoak. Hala nola irudika litekeen segidako esaldian, aditz ondoko osagaia azpimarratu nahirik (hau da, Nik Josu ikusi dudala / ETXEAN eta EZ KALEAN esate baterako) :

(53) a. Nik Josu ikusi dut ETXEAN.

b. [NIK Josu ikusi dut]PM [ETXEAN]PG ${ }^{62}$

Lehen unitateko gailur intonatiboa (eta beraz, nolabaiteko predikatiboa ere bai) unitate hasierako nik osagaiak bereganatuko du, eta ez aditz aurreko Josu objektuak.

\subsection{CORPUSEKo ANTZEKO ESALDI BI}

Atalean ikusten gatozen esaldien antzeko egitura erakutsiko luke segidakoak ere :

(54) (Bueno,) ni(k) / Josu izena dit, ... (Zestua - M) (ik. 31 irud.) $)^{63}$

Lehen osagaiak berezko intonazio unitatea osatuko du, eta bigarrenean Josu izenak bereganatuko hasierako gailurra, ondorengo isats intonatiboan emanez izena dit lokuzioa. Aldiz, oso bestelako egitura intonatibo eta informatiboa erakutsiko du (55) esaldi ez azkue-altubetarrak, osagai fokalizatua aditz ondoretik, eta aditz aurreko bi osagaiak aditzarekin batera emanak unitate beregain batean :

(55) a. Nik izena dut Anastasio. (Bidasoa - G) (ik. 40 irud.)

b. [NIK izena dut] [ANASTASIO]

Segidako esaldiak ere lehen osagai bat du aditzaren aurrean fokalizatutakoaren aurretik, eta bien arteko unitate muga bat erakutsi beharko luke :

(56) (Bueno,) ni(r)i / Lurdes gasta isena, ... (Ondarru - N28) (ik. 32 irud.) ${ }^{64}$ 


\subsection{NI + IZENA + NAIZ, EGITURA GEHIAGO CORPUSEAN}

Denera 22. (57)koez gainera, (49a, c, d, e) :

(57) a. (Bueno,) ni Aiako mutil bat naiz, ... (Aia - M)

b. (E, ja,) ni Jon Mendia naiz, ... (Arbizu - M)

c. (Bueno,) ni Mitxe naiz, ... (Ataun - G33)

d. (Bueno,) ni Txomin Mindegia nauzue, ... (Doneztebe - G)

e. (Bueno,) ni Lore naiz, ... (Eibar - N22)

f. (E,) ni Mari Doro naiz, ... (Elantxobe - N29)

g. Ni Imanol Larrañaga naiz. (Elgoibar - M25) (2. intonazio unitatea 2 irud.)

h. Ni Xabier naiz. (Elgoibar - M25) (2. intonazio unitatea 1 irud.)

i. Ni Xabier Idiakez naiz, ... (Getaria - G)

j. Ni Juantxo Apezetxea naiz, ... (Goizueta - M)

k. Ni Txomin Ostolaza naiz. (Itziar - G)

1. (Bueno,) ni Garbiñe naiz, ... (Markina - N)

m. (Bueno,) ni Ima nas, ... (Markina - N29)

n. Ni Marije naiz. (Oñati - E33)

o. Ni Gregorio Ugartemendia naiz, ... (Tolosa - G)

p. Ni Joseba Pellejero naiz, ... (Usurbil - M)

q. (Bueno,) ni Mentxu nas, ... (Zeberio - E)

r. Ni Arrasate erri txit paregabeko alkatea nauzue. (Arrasate - G)

\subsection{NI + IZENA + NAIZ + OSAGAIAK, EGITURA GEHIAGO CORPUSEAN}

Denera 19 esaldi. (58)koez gainera, (49b) :

(58) a. (Bueno, ba,) ni Juan Mari nas, Abadinokue, ... (Abadino - MG)

b. Ni Martxeli Sagastume naiz, alegritarra, ... (Alegia - N)

c. Ni Jon Iñaki Isesela nai, Isaselaia nais, hemen Arrasatekua, ... (Arrasate - M22)

d. (E,) ni Josu Zabalondo nai, bermeotarra, ... (Bermeo - G36)

e. Ni Luisa naiz, emen, Bereuten jaioa, ... (Bereute - E)

f. Ni Jose Antonio Gorostiola nas, Derion jaiokoa, oiñ, e, berrogei urte, setienbrian milla ta bederatzireun ta berrogeita amaikan. (Derio - G40)

g. (Eta) ni Jaio nas, Larrabetzukoa, ... (Larrabetzu - N)

h. Ni ere Ramon Astibia nazue, Leitzekoa, ... (Leitze - G)

i. (Bueno, e,) ni Jose Angel Larramendi naiz, i, berrogei urtekoa, ... (Orozko - G40)

j. (Ba,) ni Juan Kruz nas, eta otxandiyotarra. (Otxandio - MG)

k. Ni Nati Telletxea Juanena naiz, emen erri ontan jaiua, Urrozen, eta baserri hartan jaiua. (Urroz - E)

1. Ni Jesus Mari Beloki naiz, emen Zaldibin jaio ta azitakoa, noski, ... (Zaldibia - G)

m. Ni Eugenio Elorza neok, emen, e, Ermaso baserrian jaiotakoa, oaiñ dala ogeita bost bat urte, ... (Zegama - G25)

n. Ni Joxe Martin Uzkudun naiz, Anoetako alkatea, Ö (Anoeta - G) 
o. E,) ni Migel Mari Irigoien naiz, Etxalarko alkatea. (Etxalar - G)

p. (E,) ni Kepa Ormaetxea naiz, Mundakako alkatea, Eusko Alderdiko Ö, Eusko Alderdi Jeltzalekoa, ... (Mundaka - G)

q. Ni Germain Ezponda naiz, e, Senpereko auzapeza. (Senpere - G)

r. Ni Zubietako alkatia naiz, Patxi Mitxelena. (Zubieta - G)

\subsection{NIRE IZENA + IZENA + DA + (Ö), EGITURA GEHIAGO}

Segidako bostak dira (50)ekoaz gainera :

(59) a. Nire isena Jose Luis Obieta da. (Arratzu - G35)

b. (Eta) nere izena Maite Aristegi da. (Bergara - N27)

c. (Bueno,) nire izena Pablo da, Pablo Berriozabal, Ugarte. (Legutio - G72)

d. (Bueno,) nire isena Jaime da, ... (Lezama - G)

e. Nire izena Anjel Maria Iturbe da. (Oñati - G)

\subsection{IZENA + OSAGAI FOKALIZATUA + NAIZ, EGITURA GEHIAGO}

(51)koaz gainera segidako bi esaldiak :

(60) a. Tomas Azpiazu, Amorotoko alkatea naiz, ... (Amoroto - G)

b. Jose Mari Ezpeleta, Barrikako alkatea nas. (Barrika - G)

\section{Aditza + Izena (Aditza + "Galdegaia »), egiturak}

Atal honetan aztertu ditugu, kanon azkue-altubetarraren kontrara' esaldiko lehen predikazio gunea aditzaren ondoretik erakusten duen esaldi multzoa. Bestela esan, « galdegaia » aditzaren ondoretik erakusten duten esaldiak. Guztira 33, corpuseko 127 tik (\%26 ; ik. 12. oharra). Bi sailetan banatu ditugu. Alde batetik, aditz aurretik beste osagairen bat erakusten duten esaldiak (9.1. atala); bestetik, zuzenean naiz aditz trinkoz hasten direnak (9.2.)

\subsection{NI (EDO BESTE OSAGAiRen BAT) + AdITZA + IZENA (+ beSte OSAGAIREN BAT)}

27 esaldik erakusten du halako egitura : NI NAIZ + izena (22 esaldi) / NIRE IZENA $D A+$ izena ( 3 esaldi) / NIK IZENA DUT + izena (esaldi bat). Sail berean aztertu dugu deitzen naiz aditz konposatuz hasten den esaldi bat, DEITZEN NAIZ + izena. Segidakoen itxurakoak (ik. beste guztiak (62-65) bitarteko adibideetan) :

(61) a. (Bueno,) ni nai / Anjel Barturen, Armintzako gisona, arraintzalea. (Armintza - G) (ik. 33 irud.)

b. (Arian [?]), ni naiz / Ester, beutarra, Beuten jaioa, da hemen bizi naizena. (Bereute - E) (ik. 34 irud.)

c. (E,) ni nas / Karmelo, Berrizko mutil bat, ... (Berriz - MG27) (ik. 35 irud.)

d. (Bueno,) ni nas, a, Juan Mari Bilbao, ... (Gatika - G). (ik. 36 irud.)

e. Ni naiz / Manuela Iantzi, Lesakakua. (Lesaka - E) (ik. 37 irud.)

f. Ni nas / Jose Mari Bilbao, Jose Anjelen anaje, ... (Goierri - G) (ik. 38 irud.) 
g. (Um, ba,) nire isena da Amadeo Urrutia Arriet. (San Migel - G) (ik. 39 irud.)

h. Nik izena dut / Anastasio. (Bidasoa - G) (ik. 40 irud.)

Esaldi guztiotan izenaren aurreko ni naiz / nire izena da / nik izena dut / deitzen naiz lokuzioak, beti ematen dira intonazio unitate beregain batean, muga ongi definituekin ondoko osagarri fokalizatuarekiko. 15 esaldik pausa nabarmena dute aditz ondoan $(\% 55,6) ; 9 \mathrm{k}$ isila ( $\% 60$; ik. 33, 34, 35, 36, 38, 39, 40 irud.) ; $8 \mathrm{k}$ betea (\%53,3 ; ik. 36 irud.). Unitateko azken silabak (naiz / da / dut aditzak) ezohiko luzapena du (bikoitza edo $100 \mathrm{~ms}$ baino gehiagoko aldez) 27 esaldietako 17tan $\left(\% 63 ;\right.$ ik. 33, 34, 35, 38, 39). ${ }^{65}$ Esaldi guztiek dute nabarmen definitua intonazio etena unitateen artean, eta unitate bakoitzak bere intonazio gailur propioa, arruntki lehen unitatean oso ezkerrera eroria eta eskuin aldea oso gora igoa (ik. 33, 34, 35, $36,37,38,39,40$ irud.). Inoiz, aditzaren aurreko ni izenordea ere ematen da intonazio unitate beregain batean (ik. (63j)). Guztira ondo definituak gertatzen dira, intonazio gailurrez gain beste seinaleren batez, 19 esaldi $(\% 70,4)$. Kasurik zalantzatsuenak segidako bi esaldiak :

(62) a. (Ba,) ni nas (/) amego, San Pelaio auzokoa, Bakio pertenezitzen dau onek, bai bar, San Pelaiokoa, Jesus Olazar. (Bakio - G) (ik. lehen bi unitateak 41 irud.)

b. Ni naiz (/) alkizarra, Pedro Solarrain, basarri ontan bizi naizena, ... (Alkiza - G) (ik. lehen bi unitateak 42 irud.)

Alkizako esaldian naiz aditzak $150 \mathrm{~ms}$ inguruko iraupena du. Bakioko nas-ek, berriz, $190 \mathrm{~ms}$. Pausarik ez da, eta ondoko intonazio unitateetan (amego ; alkizarra) apenas suma litekeen grafikoan gailur propiorik, nahiz entzukeran zalantzarik ez den $(62 \mathrm{~b}) \mathrm{k}$ alkizarra osagaia nabarmen fokalizatzen duela (azentua azken silabaraino eramanez). (62a)ko amego osagaiaren entzukeran sumatzen da aditzaren ondoko intonazio etena.

Esaldiotan guztietan aditzaren intonazio unitatea ezin da predikazio marko baino izan $(\mathrm{pm})$. Lehen predikazio gunea ondoko unitateren batean etorriko da.

Ni naiz / JON itxurako esaldiaren egitura komunikatiboa PM + PG izango da, [NI naiz]PM [JON]PG ahoskatua. Kuriosoa da jabetzea, konparaketan, $\mathrm{Ni} / \mathrm{JON}$ naiz esaldiaren egitura ere halakoa dela, PM + PG. Mezu hartzaileak bi esaldiak jasoko ditu bina kolpetan, bi informazio unitate berezituetan, eta ez da ase sentituko, esaldia osatua, bigarren unitatera bitartean. Alde horretatik, ez da alde handirik bien artean, nahiz bestela bai izan.

Non da lehen unitateko gailur prosodikoa, ni ala naiz osagaietan ? Gehienetan aditzak du gailurra, baina ez beti (ik. 41 irud.). Lehen osagai ni-k gorakada handia du beti, batzuetan aditzarena bezainbestekoa ere bai ia. Zalantza egin liteke, nolanahi, aditzaren gorakada unitateko gailurrarena den edota azken silabarena. Eta hori pentsatzera eraman gaitzakete nire izena da edo nik izena dut unitate luzeagoetako grafikoek (ik. 39 eta 40 irud.). Bestalde, ez da garbi hasierako unitateko gailurra garaiagoa den ondokoetakoak baino, eta batere deklinazio prozesurik gertatzen ote den. 
Esaldion guztien ordenamendua eta egitura informatiboa bat etor liteke maiz gure inguruko $\mathrm{AO} / \mathrm{AX}$ itxurako hizkuntzek erakusten dutenarekin (Ni nai ANJEL BARTUREN ; Je m'appel ANJEL BARTUREN ; I'am Anjel Barturen ; Yo me llamo ANGEL $B A R T U R E N$; Ö). Esaldien intonazio egitura, ordea, desberdina da gure hizkuntzan eta besteetan. Gurean derrigorrezkoa da bi intonazio unitateen arteko muga aditza eta izenaren artean. Besteetan, muga beti posiblea den arren, ez da ohikoa, eta ez da eman ohi (uste dugu) euskarazko ohiko tonu gorakadarekin. Bestetik, euskarak unitateko gailur intonatibo-prosodiko-predikatiboa unitate hasieran emango duen bitartean, AO/AX hizkuntzetan, halako egituretan, unitate amaiera aldera eman ohi dute gailur prosodiko-predikatiboa ${ }^{66}$ Ezin esan liteke antzeko ordenamenduak kanpoko hizkuntzon eraginez agertu zaizkigunik euskaraz. ${ }^{67}$

\subsection{1. $\mathrm{NI}+\mathrm{NAIZ}+$ Izena (edo) + (Ö), egitura gehiago}

Segidakoak, (61a-f) eta (62a, b)koez gain :

(63) a. Ni naiz, iaemen, Manuel Arrieta. (Altza - G)

b. (Pues,) ni naiz / Felix Iriarte, emen, Arizkunen sortue, ... (Arizkun G)

c. Ni naiz, e, Simon Etxeberria Belaunzaran, basarri ontan jaiua, ... (Astigarraga - G)

d. Ni naiz / Berastegiko Jabier Saizar. (Berastegi - G)

e. Ni naiz / eratsundarra, Migel Mindegia, eta ola erri koxkor ontan, emen bizia, ... (Erasun - G)

f. (E, bueno,) ni nas, e, Miren Bilbao, ... (Larre - E57)

g. Ni naiz, e, udele, e, Legazpiko Telleriarte auzoko Juan Joxe

Aranguren, arditatik, e, a, ardikin bizi naizena, ... (Legazpia - G)

h. Ni naiz, e, Meliton, o Meli, deitzen diate erri guziyan, Meliton

Garmendia. (Lezo - G69)

i. Ni naiz / Jose Antonio Goikoetxea, ... (Muxika - G45)

j. (Bueno,) ni / naiz / Gabino Pui, emen jaiua oan dala berrogeita hemeretzi urte, sanjuandarra, ta emen iltzeko esperantzakin gañea. (Pasaia G59)

k. Ni naiz / Simon llarregi Ziaurriz. (Ultzama - G)

1. Ni naiz / Maixux Aldabe, urroztarra, emen beitiko baserri baten bizia, jaiua, ta bizi e ni(t)zena amen herrian, ... (Urrotz - E)

m. Ni naiz, i, Benito Abrisketa, ... (Zoilo - G).

n. Ni naiz / Mikaela Biana, ... (Oderiz - E)

\subsubsection{NIRE IZENA DA + Izena, egitura gehiago}

Segidakoak, (61g)koaz gain :

(64) a. (Eta) nire isena da / Jabi Arriaga. (Errigoiti - G32)

b. Nire izena da / Jose Ramon Uribe. (Aramaio - G)

Segidakoa, DEITZEN NAIZ + izena egitura erakusten duen bakarra :

(65) Deitzen, ..., naiz / Juan Luis Pagaldai, ... (Mallabi - G) 


\subsection{NAIZ (ADITZ TRINKOA BURUZURI ESALDI HASIERAN) + IZENA (+ Ö)}

Halako 6 esaldi ditugu corpusean :

(66) a. Nas / Julen Mendieta, emeko, Lemoakoa, ... (Lemoa - G33) (ik. 43 irud.)

b. Naiz / Patxi Basauri, Elgetako / alkatea. (Elgeta - G) (ik. 44 irud.)

c. Naiz / Joxe Mari Bereziartu, Ezkiokoa. (Ezkio - G)

d. (Aber,) naiz, e, Pablo, ... (Gabix - G)

e. Naiz, e Ö, Juan Pedro Urizarenbeita, Aiangizko / alkatea. (Aiangiz - G)

f. Nas / Pablo Sanpedro, Saldibarko / alkatie, ... (Zaldibar - G)

9.1. ataleko esaldietan bezala, esaldiotan guztietan ere naiz aditza unitate independente batean emango da beti, ondokoarekiko muga argiz. Aditzek intonazio gailur propioa dute (5ek ezkerra hondoan, eskuina oso gora ; ik. 43, 44 irud.), eta intonazio eten nabaria ondoko unitatearekiko. 6 esalditik 5ek erakusten du naiz aditzaren ezohiko luzapena ( $1 \mathrm{ek} 280 \mathrm{~ms}-\mathrm{koa}-41$ irud. ; eta $4 \mathrm{k} 300$ eta $399 \mathrm{~ms}$ bitartekoa -ik. 42 irud.-). Azkenotako 4k erakusten du gainera pausa (\%66,7). $2 \mathrm{k}$ isila (ik. 41 irud.), eta beste bik betea (ik. (66d, e) esaldiak). 6 esalditik 5 ek $(\% 83,3)$ erakusten du eten seinale nabarmena intonazio gailur propioez landa.

9.1. ataleko esaldietan bezala, aditzak osatzen duen intonazio unitatea ezin izango da predikazio marko baino (mintzagai), ondoko predikazio guneen zain.

\subsubsection{Aditzak ez du derrigorrez amaitzen intonazio unitatea}

9.1. eta 9.2. ataletan aztertu esaldietan, aditzak amaitzen du beti intonazio unitatea. Ez du zertan derrigor hala izan. Aditzak has lezake intonazio unitatea bertako gailur intonatibo-prosodikoa bereganatuz (eta beraz predikatiboa maila batean). Gure estatistiketan hori gertatzen da esaldien \%14,3n (Hidalgo 1994d ; 2000a). Aditza unitate hasieran emateak, beste osagaiei gailurra lapurtuz, estrategia ezaguna da gure ahozko eta idatzizko prosan kontaerari arintasuna emateko.

Aditzak, hala ere, joera nabarmenagoa du euskaraz intonazio unitate berean beste osagai baten ondoretik joateko, honen isats intonatiboan (ia beti aditz trinkoa bada, nahiz 9.2.ko esaldiak arruntak izan euskaraz -esaldien 0,8 gure estatistiketan-). Aditzak maiz bukatuko du intonazio unitatea, osagai bat + aditza egitura berez jada nahiko luzea izaki maiz. Nolanahi, hala aditza intonazio unitate buruan emanda, nola bigarren osagai bezala, zenbaitetan unitatea luza liteke aditzaren ondoretik beste osagai laburren bat emanda isats intonatiboan. Gogoratu (30)eko esaldiak. Baita aditzaren unitatea predikazio marko soil bada ere :

(67) $x$. Nor etorri da gaur zuekin?

a. (Ba,) gaur etorri dira gurekin' Ester, Imanol eta Xabi.

b. $(\mathrm{Ba}$,) gaur gurekin etorri dira' Ester, Imanol eta Xabi.

\section{Arazo ortografiko baten inguru : goiko arrasta}

8 eta 9. ataletan aztertu esaldiek arazo ortografiko sakona azalarazten digute. Ni naiz Jon bezalako esaldi bat bi modutara ahoska bailiteke (eta ahoskatu ohi da euskaraz betidanik) : 
(68) x. Ni naiz Jon.

a. NI naiz jon // [NI naiz jon]

b. Ni naiz JON // [NI naiz] [JON]

Nola jakin noiz modu batera ahoskatu, noiz bestera ? Testu-aurreak ohi du hitza. Nor zara zu ? galderaren erantzun, ez dugu (68x) esaldia (68a) gisa irakurriko, baizik (68b), Ni naiz JON. XX. mendeko joskera kanoniko azkue-altubetarrak arazoa " konpondu » du debekatzen (68b) itxurako segidak euskarazkoak ez direlakoan. Horrela eten dugu 300 urteko literatur tradizioarekin (honen 2/3ekin, gure estatistiken arabera), eta hori ez da irtenbide.

(68b)ko irakurketa eragiteko, testu-aurre egokirik gabe ere, nahikoa da etena eragin nahi den hitzaren ondoren apostrofo bat, gain jarritako koma bat, ezartzea :

(69) Ni naiz' Jon.

Goiko arrasta horrek, gainera, aurreko hitzaren amaierako goi intonazioari deitzen dio, zein den egituraren intonazioaren ezaugarri garrantzitsuetako bat, koma arruntak ez bezala. Irakurketa arazoa, nolanahi, ez da bakarrik gertatzen esaldiko " galdegaia " aditzaren ondoretik ematen duten esaldietan. Euskaraz arazoa beti gertatzen da, esaldiko lehen predikazio gunearen aurretik beste intonazio unitate independente bat eman nahi denean. Maiz ez dakigu bata non bukatzen den eta bestea hasten. Eta hau, guretzako (AO/AX hizkuntzetan ez bezala), arazo handia da, amaitzen den unitateari goi tonua eman nahiaz gain, derrigorrezkoa dugulako unitate berria gailur intonatibo-prosodikoz hastea. Horregatik ere bai, maiz, irakurketan atzera bueltatu beharra.

Ortografia zeinurik gabe arazoa dugu. Baina behin zeinu bat erabiltzea erabakita ere bai. Ze koma arrunta, maizegi, aurreko unitatea beheranzko intonazioz amaitzera garamatza, predikazioaren jarraipena iragarri gabe. Grafikoki ikusteko, (70) esaldiak, seguru asko, Jon bokatibo bezala interpretatzera garamatza, eta ez « galdegai » bezala.

(70) - Ni naiz, Jon.

Zer gertatzen (71)ko esaldia irakurtzean ?

(71) Gaur etorri dira gurekin atzo etorri ez ziren guztiak.

Esaldia luzeegia da ( 20 silaba) intonazio unitate bakarrean emana izateko gailur bakarraren pean. (71)k unitate hasierako gaur osagaia azpimarratuz, etenik gabe, 19 silabako isats intonatibo ezinezko bat eskatzen digu. Ez daukagu, ordea, laguntzarik nondik zatitu jakiteko. Esateko, gurekin osagaia lehen edo bigarren unitatean doan. Ezarri diezaiogun koma bat :

(72) Gaur etorri dira gurekin, atzo etorriez ziren guztiak.

Lehen zatia ondo irakurtzen da, [gaur etorri dira gurekin]. Komak, ordea, beheranzko intonazioa eragiten-edo du unitate amaieran. Gero konturatuko gara esaldia ez denez hor amaitzen, baina ezin dugu ezer egin lehen unitateari jada imajinatu diogun beheranzko intonazioarekin. Nola irakurtzen da orduan bigarren zatia ? Lehenaren isats intonatibo ezinezko batean ? Hala jada ohituta ez gauden bigar- 
ren predikazio gune bezala? Intonazio egokiagoa litzateke, noski, lehen unitatearen amaierako gorakada : [gaur etorri dira gurekin], bigarren predikazio gunea iragarriz. Goiko arrastak adieraziko du hori, bigarren predikazio gunea sortuz :

(73) a. Gaur etorri dira gurekin' atzo etorri ez ziren guztiak.

b. [GAUR etorri dira gurekin] [ATZO etorri ez ziren guztiak]

Areago, oraindik interpretatu behar dena baldin bada : ATZO ETORRI EZ ZIREN GUZTIAK etorri direla gaur gurekin (" galdegaia " aditz ondoretik; esateko, Nor etorri da gaur zuekin? testu-aurrearen ondoren). Goiko arrastak lagunduko digu lehen unitatearen predikazio marko-tasun hutsaz jabetzen.

Arazoak ez dira bakarrik aditz aurreratuko esaldietan gertatzen. Aditz atzeratukoetan ere, eta hauetan maiz nabarmenago. Zer gertatzen da segidako esaldia irakurtzen tarteko zeinu ortografikorik gabe?

(74) Gaur gurekin atzo etorri ez ziren guztiak etorri dira.

Atzo osagaia aurkitu orduko konturatzen gara arazo bat dugunez. Ez gara honen aurretiko intonazio unitate mugaz jabetu eta ez dugu atzo osagaia gailurtu, baina nekez joan litezke gaur eta atzo osagaiak unitate berean. Ez dugu aurrenekoan asmatu esaldia non zatitu. Koma arrunta posiblea bada ere, beharbada gogortxoa da, lehen bi osagaiak ez direlako bereziki apartagarriak :

(75) Gaur gurekin, atzo etorri ez ziren guztiak etorri dira.

Zenbaitek bi koma emanez konponduko du arazoa, hiru intonazio unitate eraginez :

(76) Gaur, gurekin, atzo etorri ez ziren guztiak etorri dira.

Goiko arrastak, seguru asko, bide erosoagoan eramango gaitu, intonazio egokia eraginez :

(77) Gaur gurekin' atzo etorri ez ziren guztiak etorri dira.

Altubek tinko heltzen dio aditz atzeratuko esaldi luzeon intonazio arazoari. Eta zorrotz ekingo dio gainezarritako komatxoaren etengabeko propagandari ( $E l$ acento vasco en la prosa y en el verso, $102-3 ; 117 ; 195-201 ; 228-9):{ }^{68}$

Este signo, con el que señalamos el final del miembro ante-inquirido (Au' Ö Ori' Ö Gizona' $O$ ), indica que ese final se pronuncia en tono recto o tenso, sosteniendo la última sílaba por lo menos a la misma altura que las anteriores ; indica además que ese miembro forma ordinariamente un tonema separado e independiente del que diseña el miembro subsiguiente, el inquirido. (117).

Altubek bere azken urteetako euskal idatzietan praktikatuko du zeinua. Asmakuntza, nolanahi, ez dagokio Azkueri baino, beti bezala. Honek praktikatzen du goiko arrasta lehen garaiko idatzi guztietan, eta hala predikatzen (Izkindea $27 ; 35-6)$ :

LENENGO ARAUA. Esaldiak ondo oguzteko' alkar mendetuta dagozan itzak' arnasa baten oguzi bear daue. / $O ̈$ / Noiz arnasa artu leiken' edo zeintzuk daizan itz alkar mendetuak' itzen goiko marratxoak dinoskue. ( 27 or.) / Ö / 89 . Goiko arrasta. Marra au barria dai ; bear bearra dai- 
lako sortu daut. Euskal itzak' euren berarizko Irizpidea gaitik' erdaldunak marrarik ipinten ez dauen lekuan bere' marraren bat bear daue' euren agerkizuna ilundu nai izan ezik. / O / 90. ¿Noiz, bada, oitu bear izango dai goiko arasta? / Arnasa artuteko peremiñaa' ta itzen agerkizuna nastuteko arrizkua dagoenean, bezte marrarik onetarako oitu al izan ezik. (35-6 orr.)

Azkuek gerora baztertu egingo du erabilera bere lanetan. Edozein modutan, garbi da halako irakurketa arazoak, nabarmen biderkatu direla XX. mendean estilo azkue-altubetar aditz atzera zalean idatzitako testuetan. Ez da halako arazorik mende honetara bitarteko literaturan (salbu Kardaberazen eskolako idazleekin), nahiz gaur egun euskara batuarekin hazitakook baditugun maiz arazok halako testu " errazak » ere irakurtzeko.

\section{ONDORIO ETA LAN HIPOTESI ZENBAIT}

Euskal esaldien informazio egitura ezagutzeko, ongi gauzatzeko, ezinbesteko da ongi ezagutzea, ongi eratzea, esaldi barneko intonazio unitateen mugak, hauen osotasunak transmitituko baitio mezu hartzaileari balio informatibo bat edo beste (predikazio marko (PM) / predikazio gune (PG)). Muga hauek ezagutarazteko, 4 baliabide erabili ohi ditu hiztunak : pausak, azken silaben luzatzeak, azken silabaren muga intonazio berezia, eta unitateetako intonazio gailur independenteak.

Euskaraz fokalizatu nahi den osagai bat beti emango da unitate baten hasieran, honen gailurra irabaziz silaba azentudunean, eta beheranzko isats intonatiboan emanez ondoko silabak, nola, enklitikoki, unitate berean eman litekeen beste osagairik. Esaldiko aditza, fokalizatu nahi den osagaia eman aurretik emana ez bada esaldian, eta agertzekoa baldin bada, salbuespen gutxirekin emango da osagai fokalizatuaren unitateko isats intonatiboan (honetan leku fisikorik baldin bada).

Unitate hasieran fokalizatu nahi den osagaiaren aurretiko osagaia, derrigorrez beste intonazio/ informazio unitate independente batean emango da (ez dirudi euskarazko intonazio unitateek onartzen dutenik gailurraren aurretik beste osagai proklitikorik, inguruko AO/AX hizkuntzetan ohikoa den bezala).

Intonazio unitate bakoitzeko oinarrizko maiztasunak egitura automatikoa gauzatuko du, azentu eta intonazio barietate bakoitzaren arabera, baina unitateko lehen osagai sintaktikoari eskainiz beti gailur intonatibo-prosodiko-predikatiboa.

Gure lan hipotesia da, hizkuntzek, modu desberdinean eratu ohi dituztela beren intonazio unitateen barne ezaugarriak. Euskara bezala OA/XA itxurako hizkuntzek, hasierako osagaiarekin emango lukete intonazio unitateko gailurra, osagai proklitikorik onartu gabe, eta, deazentuaturik, maiz beheranzko isats intonatiboan eskainiz enklitikoki beste osagairen bat (aditza barne). Hemendik hizkuntza hauen joera enklitikotasunerako, eta atzizki / posposizio sistema garatzeko. Hizkuntza hauetan bat letorke unitateko intonazio gailurra, gailur prosodiko-predikatiboarekin. Hala moduzko hizkuntzak izan litezke, euskaraz gainera, turkiera edo japoniera bezalakoak. Baita hungariera ere, honen aditz aurreko fokalizazio aukerek erakutsi moduan, nahiz, oro har, SAO ordenamendua erakutsi -euskarak bezala, egia esan-. Inoizka erakusten dute jokabide hau ere zenbait egituratan beste AO/AX itxurako hainbat hizkuntzak (frantses, ingeles, gaztelania, Ö). 
Aldiz, AO/AX itxurako hizkuntzok intonazio unitateen amaiera aldera eman ohi dute gailur prosodiko-predikatiboa (intonatiboa hasieran izanda ere). Osagai proklitikoak onartu ohi dituzte gailurraren aurretik (baita aditza ere), nahiz inoizka isats intonatibo deazentuaturik ere onartu. Hemendik, hizkuntzon joera aurrizki / preposizio sistema garatzeko.

Galdetzen dugu, OA-XA/AO-AX hizkuntzen arteko desberdintasun sintaktikoek ez ote duten azken finean oinarri aipatu intonazio unitateen barne ezaugarri dibergenteetan. Bitartean, intonazio / informazio unitateen segidak, alde gutxiz, bere batzuk izan litezke hizkuntza guztietan, eta desberdintasun sintaktikoak, oinarrian, intonazio / informazio unitate barrenetara mugatu.

\section{Resumen}

El artículo trata de acercarse a la relación de la prosodia (entonación, duración, pausas, y sobre todo de las unidades básicas de entonación así definidas) con la denominada estructura informativa de la oración, y con diversas estrategias de focalización de sus componentes. Para ello se estudian comparativamente 127 enunciados unioracionales, espontáneos, de autopresentación de 127 hablantes de otras tantas localidades que representan la totalidad de zonas del habla vasca peninsular, asi como alguna continental. Enunciados de tipologías y ordenamientos diferenciados, de una lengua de orden típico OV/XV, que se tratan de relacionar con las diversas estructuras prosódicas que ellos presentan. Con base en los diferentes datos, el artículo formula diversas hipótesis de trabajo, tanto particulares referentes a la lengua vasca, como más generales, a confirmar en estudios posteriores.

\section{Bibliografia aipatua}

ALTUBE, S. (1932) El acento vasco en la prosa y en el verso. Euskera 1932.

AzKUE, R.M. (1891) Euskal-Izkindea. Gramática Eúskara. Bilbao, 1891.

BADDELEY, A.D. (1999) Essentials of Human Memory. Psychology Press, UK, 1999.

Balota, D.A. ; Flores d'ARCAIS, G.B. ; RAYNER, K. (eds.) (1990) Comprehension Processes in Reading. L. Erlbaum, Hillsdale, N.J., 1990.

Beckman, M.E. ; J.B. PierRehumbert (1986) "Intonational structure in Japanese and English ". In Phonology Yearbook, 3, 1986, 255-309.

BOLINGER, D.L. (1972) "Accent is predictable (if you're a mind reader) ». Language, 48, 1972, 633-44.

_, (1985) Intonation and Its Parts. Melody in spoken English. Stanford Univ. Press, 1986.

$\rightarrow$ (1989) Intonation and its uses : melody in grammar and discourse. E. Arnold, London, 1989.

_, (1992) " The role of accent in extraposition and focus ». Studies in Language, 16, 1992, 265-324.

BOOMER, D.S. (1965) « Hesitation and grammatical encoding ». Language and Speech, 8, 1965, $148-158$.

BOOMER, D.S. \& DITTMAN, A.T. (1962) « Hesitation pauses and juncture pauses in speech ». Language and Speech, 5, 1962, 215-20.

BOOMER, D.S. \& LAVER, J. (1968) «Slips of the tongue ». British Journal of Disorders of Communication, 8, 1968, 2-12 (reprinted in Fromkin, V.A. (ed.), 1973, Speech Errors as Linguistic Evidence, Mouton, The Hague, 120-31 ; eta J. Laver, 1991, The Gift of Speech, Edinbourgh Univ. Press, 1991, 23-35).

Brown, G. (1983) « Prosodic Structure and the Given/New Distinction ». In A. Cutler ; D.R. Ladd (eds.), Prosody : Models and Measurements. Berlin, Springer, 67-77. 
Brown, G. ; Yule, G., (1983) Discourse analysis. Cambridge Univ. Press, London, 1983.

Brown, G. ; K. CURRIE ; J. KenwORTHY (1980) Questions of intonation. Croom Helm, London.

ChafE, W.L. (1979) «The Flow of Thought and the Flow of Language ". In Syntax and Semantics 12, Discourse and Syntax, T. Givon (ed.), Academic Press, 159-181.

$\longrightarrow$ (1980) (ed.) The pear stories : Cognitive, cultural, and linguistics aspects of narrative production. Norwood NJ : Ablex.

_, (1987) " Cognitive constraints on information flow ». In R. Tomlin (ed.), Coherence and grounding in discourse. Typological Studies in Language, XI, Amsterdam, John Benjamins, 21-52.

—, (1988) “ Linking intonation units in spoken English ». In J. Haiman ; S.A. Thompson (eds.) Clause Combining in Grammar and Discourse, John Benjamins Publishing Comp., 1988, 1-27.

_, (1988) « Punctuation and the prosody of written language ». Written Communication, 5, 1988, 395-426.

_, (1992) « The importance of corpus linguistics to understanding the nature of language ». In J. Svartvik (ed.) Directions in Corpus Linguistics, Mouton de Gruyter, 1992, 79-103.

_, (1992) « Intonation Units and Prominences in English Natural Discourse». In Proceedings of the IRCS Workshop on Prosody in Natural Speech, Institute for Research in Cognitive Science, Report $n^{\circ}$ 92-37, Philadelphia, University of Pennsylvania, 41-52.

_, (1992) « Information flow in speaking and writing ». In P. Downing, S.D. Lima, M. Noonan (eds.) The linguistics of literacy, Amsterdam, John Benjamins, 17-29.

_, (1993) « Prosodic and Functional Units of Language ». In Edwards, J.A. ; Lampert, M.D. (eds.) (1993) Talking data : Transcription and coding in discourse research. Hillsdale, NJ, Lawrence Erlbaum, 1993, 33-43.

_, (1994) Discourse consciousness, and time : The flow and displacement of conscious experience in speaking and writing. Chicago, The University of Chicago Press, 1994.

ChAFE, W. ; Du BoIs, J.W. ; S.A. THOMPSON (1991) « Towards a new corpus os spoken American English ». In K. Aijmer \& B. Altenberg (eds.) English Corpus Linguistics, Longman, London \& New York, 1991, 64-82.

Clark, H. (1996) Using language. Cambridge Univ. Press, Cambridge, U.K.

Clark, H.H. ; E.V. ClarK (1977) Psychology and Language. An Introduction to psycholinguistics. Harcourt Brace, New York, 1977.

Coltheart, M. (1987) The Psychology of Reading. Attention and Performance XII. L. Erlbaum, 1987.

CRUTtEnden, A. (1986) Intonation. Cambridge Univ. Press, London, 1986. 2nd ed. 1997.

DE VEGA, M. ; F. CuETOS (coord.) (1999) Psicolingüistica del español. Trotta, Madrid, 1999.

DitTMAN A.T. ; LleWELLYN, L.G. (1967) « The phonemic clause as a unit of speech decoding ». Journal of Personality and Social Psychology, 6, 1967, 341-9.

ElordieTA, G. (1997) « Accent, tone, and intonation in Lekeitio Basque ». In F. Martinez \& A. MoralesFront (eds.), Issues in the Phonology and Morphology of the Major Iberian Languages, Georgetown Univ. Press, Washington D.C., 1997, 3-78.

—, (1998) « Intonation in a pitch accent Variety of Basque ». $A S J U, 1998,511-569$.

, (2000) « Mendebaldeko intonazioaren inguruan ». In Mendebaldeko Berbetearen Formalizazinoa, Bilbao 2000, Mendebalde Euskal Kultur Elkartea, 111-136.

_, (agertzekoa) « Primer estudio comparativo de la entonación de tres variedades dialectales vascas ». Actas del I Congreso de Fonética Experimental, Barcelona, Univ. de Barcelona.

_. (agertzekoa) « Intonation ». In A Grammar of Basque, J.I. Hualde (ed.), Mouton de Gruyter, Berlin.

- (agertzeko) « Primer estudio comparativo de la entonación de tres variedades dialectales vascas ». In Actas del I Congreso de Fonética Experimental, Barcelona : Servicio editorial de la Universitat de Barcelona

ElordietA, G. (et al.) (1999) «Another step in the modeling of basque intonation : Bermeo ». In V. Matouek (eta al) (eds.) (Proceedings of the Workshop on) Text, Speech and Dialogue, Pilsen, Czech Republic, 3614.

Eysenck, M.W. ; Keane, M.T. (1995) Cognitive Psychology. Psychology Press.

FAYOL, M. (et al.) (1992) Psychologie cognitive de la lecture. PUF, 1992, Paris. 
FÉRY, C. (1992) Focus, Topic and Intonation in German. Univ. of Stuttgart, Arbeitspapiere des Sonderforschungsbereichs 340, Bericht, Nr. 20-1992.

— (1993) German Intonational Patterns. Tübingen, Newmeyer, 1993.

FIRBAS, J. (1992) Functional sentence perspective in written and spoken communication. Cambridge Univ. Press, 1992 ( 1995 reprinted).

FOLEY, W.A. ; VALIN R.D. van (Jr.) (1985) "Information packaging in the clause ". In T. Shopen (ed.), Language typology and syntactic description, Vol. I, Cambridge University Press, 1985, 282-364

FreTHEIM, T. (1987) "Pragmatics and Intonation ». In J. Verschueren, M. Baertucelli-Papi (eds.) The Pragmatic Perspective, J. Benjamins, 1987, 395-420.

GAMINDE, I. (1996) «Lesakako azentu eta intonazioaz ». FLV, 71.

—, (1997) Gatikako euskaraz. Gatikako Gogoz Euskara Taldea, 1997.

_, (2000) “ Eibarko euskararen intonazioaz ». FLV 2000, 37-52.

, (2000) «Zamudioko euskararen soinu egituraz ». In Mendebaldeko Berbetearen Formalizazinoa, Bilbao 2000, Mendebalde Euskal Kultur Elkartea, 159-179.

GAMINDE, I. ; HAZAS, A. (1998) « Zumaiako azentuaz eta intonazioaz ». Uztaro 24, 1998, 59-76.

GAMINDE, I. (eta beste) (1995) «Zeanuriko intonazioaz ». Ele, 16, 1995, 97-121.

GAMINDE, I. (eta beste) (1996) « Euskalfonologiaren didaktikarantz : Intonazioaren azterketa ». Revista de Psicodidáctica, 1, 1996, 121-138.

GAMINDE, I. (eta beste) (1997) " An Analysis of the Intonation for a Pitch Accent Variety of the Basque Language ». In Botinis, A. (et al) (eds.) Intonation : Theory, Models and Applications. Proceedings of an ESCA Workshop, Athens, Grezia, 1997, 137-140.

GAMINDE, I. (eta beste) (1998) «Azentu, intonazio eta silabifikazioen funtzio bereizleez ». Revista de Psicodidáctica, 6, 1998, 79-98.

GAMINDE, I. (eta beste) (1999) « Euskal azentuaren pertzepzioa irakasleen artean ». Ele, 19, 1999, 41-55.

GARRET, M.F. (1975) «The analysis of sentence production ». In G. Bower (ed.) The Psychology of Learning and Motivation : Advances in Research and Theory, 9, 133-177. New York, Academic Press.

$\longrightarrow$ (1976) «Syntactic processes in sentence production ». In R. Wales : E. Walker (eds.) New appoaches to Language Mechanisms, 231-256, Amsterdam, North Holland Press.

— (1978) «Word and sentence perception ». In R. Held (et al.) (eds.) Handbook of Sensory Phisiology, VIII : Perception, 611-625. New York/Heidelberg : Springer.

_, (1980) « Levels of processing in sentence production ». In B. Butterworth (ed.), Language production (vol. I), London, Academic Press, 1980.

_, (1988) « Processes in Language production ». In F. Newmeyer (ed.) Linguistics : The Cambridge Survey. Vol. III Language : Psychological and Biological aspects. 69-96. New York : Cambridge, Uni. Press.

_, (1990) «Sentence Processing ». In Osherson, D.N. y Lasnik, H.(eds.), 1990, Language : an invitation to cognitive science, Vol. 1, Cambridge. Massachusetts, MIT Press.

$\longrightarrow$ (1992) « The Structure of Language Processing : Neuropsychological Evidence ». In Gazzaniga (ed.) Cognitive Neuroscience, 881-899.

_, (1993) « Errors and their Relevance for Models of Language Production». In G. Blanken (et al.) (eds.) Linguistic Disorders and Pathologies, Walter de Gruyter, 1993, 72-92.

_,(2000) Cotemporary language processing models. Perspectives fron Cognitive Science. (A course) EHU, Gasteiz, May-Juin, 2000.

GARRETT, M.F. ;T. BEVER ; J.A. FODOR (1966) «The active use of grammar in speech perception ». Perception and Psychophysics, 1, 1966, 30-32.

GatherCole, S.E. ; A.D. BADDELEY (1993) Working Memory and Language. L. Erlbaum, 1995.

Gernsbacher, M.A. (ed.) (1994) Handbook of Psycholinguistics. Academic Press, 1994.

HABerLANDT, K. (1997) Cognitive Psychology. Allyn and Bacon (1st ed. 1994).

HALLIDAY, M.A.K., (1967) " Notes on transitivity and theme in English », II, Journal of Linguistics, 3, 1967, 199-244.

HIDALGo, V. (1991) Altuberen azterketan. (Lan argitaragabea, doktoretza tesian aurkeztua, orain kontsulta Jitekeena : http ://www. euskalnet. net/vhidalgo). 
_, (1993) Hitzen ordena euskaraz. Euskal gramatikalarien testigantza : iritziak eta, praktika idatziak. (Lan argitaragabea, doktoretza tesian aurkeztua, orain kontsulta litekeena : http ://www. euskalnet. net/vhidalgo).

_, (1994a) « Euskal joskeraren mito kaltegarriak (I). Nola idatzi euskaraz modu arin, ulergarri eta aberats batean. " Hizpide, 35, 1996, 39-51.

_, (1994b) « Euskararen hitz ordena librea. Euskal joskeraren mito kaltegarriak (II) » Hizpide, 36, 1996, $21-27$.

_. (1994c) « Aditza maiz euskaraz esaldi hasieran. Euskal joskeraren mito kaltegarriak (III) » Hizpide 37, 1996, 23-31

_, (1994d) Hitz ordenaren estatistikak euskaraz. (Lan argitaragabea, doktoretza tesian aurkeztua, orain kontsulta litekeena : http ://www. euskalnet. net/vhidaigo).

— (1995) " Ohar estatistiko garrantzitsuak euskararen hitz ordenaren inguru. Euskara, SVO ? ». FLV, 70, $1995,401-420$.

—, (1996) « Hurbiltze bat euskal hitz ordenaren tradizioari ». FLV, 71, 1996, 21-43.

_. J. Garzia (1997) « Hidalgo vs Altube ». El Correo, Territorios, 10, 1997-XI-5.

_, J. Garzla (1998) « Ikastea pentsatzen euskaraz ». In Administrazioa euskaraz, 19, 1998 Urtarrila, 19.

_, (1998) « Baina, zer da euskal joskera? ». In Administrazioa euskaraz, 21, 1998ko uztaila, 18-9.

_, (1999a) « Hitzen ordena eta esaldiaren egitura informatiboa. Gogoeta historiko zenbaiten berri labur. Antzinatea ». FLV 82, 1999, 431-457.

_, (1999b) « Axular euskal hitzen ordenaren historian ". Lapurdum IV, Numéro Spécial 1, Les lettres basques au temps d'Axular (1600-1650). Euskal literatura Axularren aroan. Actes du colloque de Bayonne (12-13 avril 1999), 1999, 143-170.

_, (2000a) « Hitz ordenaren estatistikak euskaraz ». Anuario del Seminario Julio de Urquijo, 1999-2.

_., (2000b) «"Galdegai" bat baino gehiago erakutsi ohi duten esaldiez. Hitzen ordena esaldian : bereizi beharreko eztabaida arlo bi. Galdegaiaren inguruko ikuspegi berri bila (I) ». Uztaro 33, 2000, 44-85.

_. (2000c) « Informazio unitate baten tamainako esaldi laburraren ordenamendu eta informazio-egituraren aukerak eta eraginak. Hitzen ordena esaldian : bereizi beharreko eztabaida arlo bi. Galdegaiaren inguruko ikuspegi berri bila (II) ». Uztano 34, 2000, 39-85.

HUALDE, J.I. (1986) « Tone and stress in Basque : a Preliminary Study ». ASJU XX-3, 1986, 867-896.

Hualde, J.I. ; X. Bubao (1993) «The prosodic system of the Basque dialect of Getxo : A metrical analysis $).$ Linguistics, 31, 1993, 59-85.

Hualde, J.I. ; Elordieta, G. ; Elordieta, A. (1993) « Focalización y prosodia en vascuence vizcaíno ». $A S J U, 1993,731-749$.

_. (1994) The Basque Dialect of Lekeitio. Supplements of ASJU, Donostia, 1994.

JANSEN, W. (1992) «Acento y entonación en Elorrio ». ASJU, 1992, 67-109.

JUN, S.-A. ; G. EloRDIETA (1997) «Intonational structure of Lekeitio Basque ». In Intonation : Theory, models and applications. Proceedings of an ESCA Workshop, A. Botinis (et al.) (eds.), Athens, 193-196.

LADD, R. (1996) Intonational Phonology. Cambridge Univ. Press, 1996.

LADD, D.R. ; W.N. CAMPBELI (1991) "Theories of prosodic structure : evidence from syllable duration". In Proceedings of the XIIth International Congress of Phonetic Sciences, 290-293.

LAVENDER FrLmS (1989-1993) Euskararen bidean. (Bideo Saila). Gasteiz.

LAVER, J. (1970) "The production of speech ". In. J. Lyons (ed.), New Horizons in Linguistics. Penguin, New York, 1970 ; Nuevos horizontes de la lingülstica, Alianza, Madrid, 1975, 55-77.

LEvelt, W.J. (1989) Speaking : From Intention to Articulation. Cambridge, Mass., MIT Press, 1989.

Medin, D.L. ; Ross, B.H. (1997) Cognitive Psychology. Harcourt Brace Coll. Publ. (1st ed. 1992).

Merer, A.S. (1996) « Lexical Access in Phrase and Sentence Production : results from Picture-Word Interference Experiments \%. Journal of memory and Language, 35, 1996, 477-496.

Navarro Tomas, T., (1939) «El grupo fónico como unidad melódica ». Revista de Filologia Hispánica, I, $1,1939,3-19$

_., (1944) Manual de entonación española. New York, 1944. $4^{\text {a }}$ ed., Guadarrama, Madrid, 1974.

NesPor, M. ; VOGEL, I. (1986) Prosodic phonology. Dordrecht, Foris, 1986. 
PierRehumberT, J.B. ; BeCKman, m. (1989) Japanese Tone Structure. Cambridge, Massachusetts, MIT Press, 1989.

PIERREHUMBert, J. ; J. HiRSCHBERG (1990) "The Meaning of Intonational Contours in the Interpretation of Discourse ". In Cohen, R., J. Morgan, M.E. Pollack (eds.) (1990) Intentions in Communication, Cambridge, Mass. MIT Press, 271-312.

$\longrightarrow$ (1990) HoBBs, J.R. « The Pierrehumbert-Hirschberg Theory of Intonational Meaning Made Simple : Comments on Pierrehumbert and Hirschberg ". In Cohen, R., J. Morgan, M.E. Pollack (eds.) (1990) Intentions in Communication, Cambridge, Mass. MIT Press, 313-23.

PricE, P. (et al.) (1991) «The use of prosody in syntactic disambiguation ». Journal of the Acoustical Society of America, 90 (6), 2956-2970.

PRrTCHET, B.L. (1988) « Garden Path Phenomena and the Grammatical Basis of Language Processing ». Language, 64, 1988, 539-576.

Rayner, K. ; A. Pollatsek (1989) The Psychology of Reading. Prentice-Hall, New Jersey, 1989.

SELKIRK, E. (1984) Phonology and Syntax : the relation between sound and structure. Cambridge, Mass., MIT Press, 1986.

—(1995) « Sentence Prosody : Intonation, Stress, and Phrasing ». In J.A. Goldsmith (ed.), The Handbook of Phonological Theory, Blackwell, 1995, Cambridge, Mass., USA / Oxford, UK.

Singer, M. (1990) Psychologie of Language. An introduction to Sentence and Discourse Processes. L. Erlbaum Ass. Publishers, Hillsdale, New Jersey, 1990.

STEEDMAN, M. (1991) «Structure and Intonation ». Language, 67, 1991, 260-296.

SternBerg, R.J. (1996) Cognitive Psychology. Harcourt Brace, Fort Worth Ö, 1996.

SVARTVIK, J. (ed.) (1990) The London-Lund Corpus of Spoken English. Lund : Lund Univ. Press, 1990.

TOLEDO, G.A. (1989) « Señales prosódicas del foco ». Revista Argentina de Lingüistica, 5, 1-2, 205-230.

WELLS, W.H.G. (1986) «An Experimental Approach to the Interpretation of Focus in Spoken English ». In Johns-Lewis, C. (ed.) Intonation in Discourse. Croom Helm, Australia, 1986, 53-75.

ZAGAR, D. (1992) «L'approche cognitive de la lecture : de l'accès au lexique au calcul syntaxique ». In FAYOL, M. (et al.), Psychologie cognitive de la lecture. PUF, 1992, Paris, 15-72.

\section{Notes}

1. Lan hau burutu ahal izan da, besteak beste, Eusko Jaurlaritzaren laguntzari esker ere bai, honen Hezkuntza, Unibertsitate eta Ikerketa Sailak ikertzaileak prestatzeko zabaldutako programetako beka baten bidez 1998-99 eta 1999-2000 ikasturteetarako. Ikasturte bietan autorea Baionako Unibertsitate Arteko IKER Euskarari eta Euskal Testuei Buruzko Ikerketa Taldean aritu da lanean (umr 5478/CNRS - Université Michel de Montaigne Bordeaux III-UPPA), Beñat Oihartzabal zuzendariaren gidaritzapean.

2. Batez ere ingelesaren inguruan burutuak, nahiz besterik ere baden. Ik. besteak beste, bibliografian aipatu Beckman, Bolinger, Brown, Cruttenden, Féry, Fretheim, Ladd, Nespor eta Vogel, Pierrehumbert, Selkirk edo Steedman-en lanak. Euskararen inguruan, Elordieta, Gaminde, Hualde, Hidalgo 2000b-c, Jansen, eta Jun-enak.

3. 2000ko ekainean Baionako IKER taldearen aurrean eginiko hitzaldian oinarri hartuta.

4. Baita esaldi hauek hizkuntza batean emanda, lekukoari eskatuta helburu hizkuntzara itzulita emateko. Chafe irakasle amerikarraren eskola izan liteke bide horietatik nabarmen aldentzen dena. Ik. bibliografian aipatutako bere zenbait lan, prosodia eta esaldien egitura informatiboa lotzen. Baita ere Lund-eko unibertsitatearen inguruko taldea, J. Svartvik-ekin.

5. Zer esanik ez itzulpen jokoekin, hizkuntza arteko interferentziak, saihestu gabe, ezin ageriagoan eraginez.

6. Desberdin da' mezu hartzaileari ezagutzera eman nahi zaion testu baten irakurtzea, eman dezagun jendaurreko eleberri baten irakurketa.

7. Testu-aurre kontzeptua darabilgu ohiko testuinguru-renaren ordez, azpimarratu nahian, mezu hartzaileak zeinahi esaldi atalen lehen interpretaziorako, soilik ordura bitarteko informazioa (testu-aurrea) erabil lezakeela, eta ez esaldi atal horren ondotik eman litekeena (testu-ondoa). 
8. Esaldien ondoren, parentesi artean herriaren izena ematen dugu, eta ondorean N(eska), M(util), $\mathrm{G}$ (izon), E(mazte) letrak -batzuetan adina adierazten dituen zenbaki batek lagunduak-, lekukoen adinaren erreferentzia.

9. Artikulu amaierako eranskinean jaso ditugu hainbat esaldiren oinarrizko maiztasunekin osatutako grafikoak. Zenbat eta ahots korden bibrazio gehiago, orduan eta tonu altuagoa. Haurrek eta emakumezkoek, berez erakutsi ohi dute tonu altuagoa. Prosodia kontuetan, ordea, ez dirudi garrantzi berezirik dutenik neurri absolutuek, baizik eta hiztun bere baten gorabeherek. Grafikoak lortzeko, eta oro har, esaldien prosodia eta intonazioaren inguruan eginiko azterketa lan osorako baliatu gara AHOT azterketa programa informatikoaz, azken urteotan Inma Hernaez irakaslearen taldeak garatua Bilboko Injinerutza Eskolan (eskerrak hemendik ere guztiei). AHOTek ez du bakarrik eskaintzen oinarrizko maiztasunaren kurba. Neur ditzake ahots intentsitatea eta anplitudea, eta erakutsi soinuen espektrograma. Gure azterketarako aukera guztioz baliatu garen arren, ez dugu uste izan hauen guztien emateak asko laguntzen zuenik esaldien begi bistako interpretazioan. Intonazio kutben azpiko legendan, une bakoitzari dagokion soinua idatzi dugu (gehienean, eta bokalen kasuan behintzat, unearen hasieran). Legendaren azpian, esaldiaren iraupenaren eskala milisegundotan. Grafikoetako leiho guztiek (bertan berezi aipatu hiruk salbu) dute 200 Hzetako zabalera, nahiz hiztunaren arabera zabalera hau altura desberdinen artekoa izan, grafikoaren gainean erakusten den legean. Grafikoaren gainean, eskuinean ematen da esaldiaren iraupena.

10. Ez dugu corpusean aditz aurretik bi baino osagai gehiago duen esaldirik. Bai zenbait, bueno, ba edo itxurako esamoldez hasiak. Halakoak, esaldi hasieran, ez ditugu esaldi barrenekotzat eman.

11. Nahiz eta esaldia, deitzen partizipioa eta naiz-en artean erakusten duen etenaren kausaz, kontsidera litekeen zuzenean naiz aditz flexioz hasten denetakoa, segidako sailekoak bezalakoa.

12. Kopuru nahikoa baxua datuak parekatuz gero ahozko beste corpus orekatuagoekin. Hidalgo 1994d eta 2000a-n erakusten da, ahozko hizkeran 3 esalditik batek baino ez ohi duela bete Azkue-Altuberen galdegai legea. Beste bi herenek erakutsi ohi dute esaldiko predikazio nagusia osorik emana aditzaren ondoretik. Kurioski, datu bertsuak eskaintzen ditu literatura idatzi klasikoaren azterketak (Axular, Mogel, J.B. Agirre, Duvoisin, J. Etxepare). Hemen aztertu aurkezpen egituren 4tik l ek baino ez ematea galdegaia aditz ondoretik, egituraren arrunt, labur eta beharbada maiztasunarekin lotu behar da.

13. Intonazio unitateen ezaugarrien gainean ik. Hidalgo 2000b, c. Baita ere Cruttenden 1997, eta hasierako eta oinarrizko lan, Navarro Tomás-enak.

14. Nahiz ez dugun hemen azentuaziorik aztertuko, berau ere prosodiaren esparruko, zalantza gabeko eragin zuzena duena intonazioan.

15. Ik Hidalgo 1999a.

16. Hala deitu diogu guk, ik. Hidalgo $2000 \mathrm{~b}$, c.

17. Hitzaren esanahi zehatzari lotua, nola esaldian betetzen duen funtzioari : aditzak subjektuak baino handiago ; objektuek aditzak baino ; Ö, ik. Firbas 1992.

18. Bere testu-aurre zehatzari lotua, eta honi dion mendekotasun mailaren araberakoa.

19. I, II eta III ataletako esaldi gehienek betetzen dute oinarrizko eskema hau, nahiz zenbait eranskinekin. Hemen aipatutako ezaugarriak era bertsuan sumatu ahal izanen dira eranskinean ematen ditugun lehen 32 iruditan ere.

20. Alor honetan dugun ezjakintasunaz jabetzeko egin dakieke begiratu bat, Wells edo Toledo-renak bezalako lanei, fokalizazioa eta prosodiaren arteko loturen inguru, ingelesez edo espainolez.

21. Nahiz, berez, Juan Antonio naiz bezalako esaldi baten ahoskatze kanoniko batek 7 silaba izan litzakeen, kasuan ez ditu. Intonazio unitate baten ohiko neurria 10 silaba azpitikoa da, 8 silaba bitartekoak ohikoenak, eta segundo baten azpitik emanak. Inoiz, salbuespen bezala, luzeagoak, 14-15 silabetaraino unitateko beheranzko isats intonatiboan. Silaba baten ohiko ahoskatzeak 0,11 edo 0,12 segundo hartu ohi du batez beste, eta 10 silabako segida etenik gabeko batek 1,1 edo 1,2 segundo.

22. Esaldi hauek, Xabier naiz. (Elgoibar - M25) (1. irudia) eta Imanol Larrañaga naiz. (Elgoibar - M25) (2. irud.), berez, aurretik ni izenorde pertsonala ematen dute intonazio unitate independente batean (Ni / Xabier naiz ; $\overparen{O}$ ). Kasuan ez dugu jaso bigarren unitatearen intonazioa baino, erakutsi nahi duguna argiago izanen delakoan. Hauen antzeko esaldi osoen grafikoak ikus litezke 19tik 31 ra bitarteko irudietan.

24. Beste kontu bat da uste izatea hiztunak inoizka kausa bat edo besteagatik ez duela aurreko unitatea planifikatu bezain luze eman eta etenda edo utzi duela. Edonola, ondoko unitatea, berria izanen da hasten den lekuan hasita, eta mezu hartzaileak, aurreko unitate « etena » prozesatu eta gero prozesatuko du bigarren unitate bezala.

25. Intonazio gailurrak, hala ere, eman litezke euskaraz, hitz azentu lexikodun markatuen eragin soilez. Azterketa azkarragoak behar genituzke, batzuen eta besteen arteko desberdintasunak azaltzeko. 
Desberdintasunik ez balego, nekez postulatu ahal izango genuke gailur intonatibo nagusi bakoitzak intonazio unitate propioa adierazten duela, lan honetako emaitzek aditzera eman moduan. Gure ustea da, azentu lexikoak, intonazio unitateko gailurrarekin bat ez datozenean (hau da, unitateko beheranzko isats intonatiboan ematen direnean), hainbat deazentuatuak eta indargabetuak gertatzen direla, nahiz artean nabarmendu

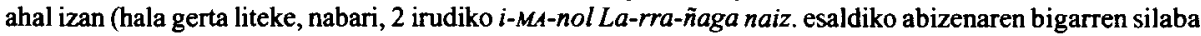
azentudunarekin).

26. Nolanahi, orain artean euskararen intonazioa aztertzen aritu diren ikerlari gehienek (Elordieta, Gaminde, Hualde, Jun) argi diote Bizkaiko iparraldeko intonazio sisteman, esateko, oinarrizko maiztasun kurbak ez duela inondik ere bereizten intonazio unitate desberdinik aditzaren aurreko sintagma fokalizatua eta honen aurrekoaren artean (hau azentu lexiko bereziz markatu gabea den bitartean), biak ere gailur intonatibo beraren pean kokatuz. Gailur bera luzatuko litzateke lehen osagaiaren bigarren silabatik, bigarren osagaiaren silaba azentuduneraino, handik zuzen behera amiltzeko intonazio unitatearen amaieraraino : laguna Bilbóra jun da bezalako esaldi bat (Elordieta, 2000) [la/GUNA BILBÓ ‘ra jun da] itxuran (ik. besteak beste Elordieta 2000 ; Gaminde 2000). Halako datu batek zalantzan jarriko luke intonazio unitateen mugatzeko 4. ezaugarriaren unibertsaltasuna. Edota, guztiok beti postulatu dugunaren kontrara, pentsatzen hasi beharko genuke, litekeena dela, intonazio unitate bakarrean ematea, tarteko inolako etenik gabe, aditzaren aurreko osagai fokalizatua ( galdegaia ») eta honen aurrekoa. Azterketa honetako emaitzak bestelakoak dira.

Eta gure begirada propioak Bizkaiko iparraldeko hala moduzko esaldiei (besteak beste, Iñaki Gaminderi esker erabili ditugun Jatabe eta Mungiako grabazioetan ; edota corpus honetako 26 irudian), nahiz antzekoak, beste emaitza batzuk iradokitzen dizkigute. Guztietan aurkitu dugu tonua lehen osagaiaren bigarren silaban igotzen dela, eta beharbada zertxobait jaitsita (ezer gutxi), goi tonu berori mantentzen dela lehen osagaiaren azken silaba bitartean (eta are bigarren osagaiaren lehen silaban bertan ere) (ik. 26 irud.). Gero, ordea, bigarren osagaiaren lehen silaba honetan tonua zertxobait jaitsita (ez hasierako edo amaierako hondoraino, eta are tonua mantenduz inoiz), hau beti nabarmen igotzen dela ( $10 \mathrm{~Hz}$ gutxieneko aurreko silabarekiko) aditz aurreko bigarren osagai fokalizatuaren silaba azentudunean (ik. 26 irudian $i$-tzi-ar-en bigarren silaba), gero hor bertan amiltzeko hondoraino hurrengo silaban bertan (26 irudiko azken silabako gorakada, azken silabaren goranzko muga intonazio berezia litzateke). Guk, orain arte begiratutako esaldietan beti topatu dugu aditz aurreko osagai fokalizatuaren silaba azentudunean gailur intonatibo propio bat erraz bereizi litekeena aurreko goi tonu mantendu horretatik. Nolanahi, era horretako hizketa naturaleko esaldietan nabarmen gertatzen da bi unitateen arteko etenaren beste seinalerik (pausa, edo azken silabaren luzatzea, 26ko irudiko esaldian bezalaxe, non nire isena-ren azken bokala 300 bat ms-z luzatzen den -isena hitzaren ahoskatze arrunta bezain beste-). Beste seinale hauek, noski, nekez aurkitzen dira hiztunak apropos prestatutako esaldiak irakurtzean. Ez gara gu, nolanahi, aritu / adituenak hala moduzko esaldietan.

27. Hau ohi da tonu azentua erakutsi ohi duten hizkuntzen ezaugarri, silaba azentudunak oinarrizko maiztasunaren gailur batez adieraziz (eta agian honi loturiko beste ezaugarriez ere).

28. Grafiko azpiko legendetan [ ], parentesi zuzenak erabili ditugu intonazio unitateak mugatzeko. Unitate amaierako bokal edo kontsonanteren ondoren, = zeinuaren bidez adierazi dugu honen ezohiko luzapena.

29. 2 irudian gailurra Imanol izenaren erdiko silabak ageri du (gailurra honen amaieran), eta bertan hasten da unitateko intonazio beherakada. Hala ere, Larrañaga abizenaren bigarren silabarekin suma liteke gailur txiki berria. Intonazio unitate berria ? Ez dirudi. laRRañaga hitzaren berezko azentuazioak, isolaturik emana, edota unitate hasieran laRRañaga naiz itxurako esaldi batean, askoz ere gailur intonatibo nabarmenagoa erakutsiko luke. Abizena izenaren gailur intonatiboaren isatsean emateak, intonazio unitate beraren barne, ez dio azentua erabat galarazten, baina bai ahultzen.

30. Ik. 26. oharrean esana. Nolanahi, gure neurketak ez dira beti nahi bezain zehatzak. Fonemen arteko mugak ez dira garbiak eta trantsizioak gradualak dira. Kontsonante ahoskabeek ez dute ahots korden dardararik eragiten eta honek (kurba begi bistatik desagerrarazteaz gain) ondorioak ditu ondoko soinuen (bokalen) tonuan. Gainera bokal bakoitzak izan ohi du bere barne tonu propioa, euskaraz sobera ongi ezagutzen ez duguna, eta aldatu ere egin ohi da hasieratik amaierara. Kontsonanteekin ere badira berezitasunak. /b//d/ edo/g/soinuek behera eragiten diote tonuari./n/-k gora. I. Gaminderi zor dizkiot halako eta beste mila motatako zehaztasunak, nirekin galdu behar izan duen denbora neurrigabearen fruitu.

31. Eta hala moduz, 7 irudiko azken intonazio unitatean ; edo 12tik 20ra bitarteko azken unitatetan.

32. Aipatu Bizkaia iparraldeko ereduaren ikerlariek, hala ere, diote, eredu honetan esaldi barreneko intonazio unitateek, nahiz jarraipena izan edo behar, ez ohi dutela amaierako goranzko intonaziorik erakusten.

33. Baita ere 7 irudiko lehen hiru intonazio unitateen amaieran, edo apalagoa, 6 irudiko lehen intonazio unitatean. Baita ere ondorengo grafiko gehienetako unitateren batean bederen. 
34. Horrelako zerbait esan nahi ote du Azkuek Izkindean esaldi hasierako gunea eskaintzen dionean galdegaiari? rik.

35. Edota beharbada [ESter etorri da] izena euskarazko era hipotetiko batean azentuatu eta ahoskatu-

36. Guk gerok penintsula zabaleko gaztelaniaz aztertu hainbat aurkezpen esalditan.

37. Egin ditugu zenbait azterketa konparatibo frantses eta gaztelaniazko ehun bat aurkezpen egiturarekin, baina oraindik ez gara gauza hauek behar bezala interpretatu eta ondorio erakusgarriak aurreratzeko hizkuntzon azterketa zabalago eta sakonagorik gabe.

38. Kontuotaz dihardugu zabalxeago Hidalgo 2000b, c-n. Jada Halliday 1967k egiten du intonazioinformazio unitateen arteko parekatzea. Bide horretan abiatu dituzte urte batzuk lehenago beren ikerketak Boomer, Dittman, Llewellyn eta Laver bezalako ikerlariek, gero psikolinguistikan eta psikologia kognitiboaren alorretan jarraituak. Psikolinguistika eta psikologia kognitiboaren inguruan ikus litezke esaldien sortze eta entzute, irakurtze eta ulertze prozesuen inguruan, eta giza gaitasun mnemoteknikoenean, beste askoren artean, bibliografian aipatu : Clark \& Clark 1977 ; Levelt 1989 (1995); Singer 1990 ; Gathercole \& Baddeley 1994 ; Chafe 1994 ; Gernsbacher 1994 ; Eysenk-Keane 1995 ; Clark 1996 ; Sternberg 1996; Haberlandt 1997 ; Meyer 1996 ; Medin-Ross 1997 edo berrikiago Baddeley 1999n esaten direnak. Baita ere Garrett-en lanak edo Balota (eta beste), Foley, Pritchett, Rayner eta Pollatsek, edo Zagar-enak. Gaztelaniaz ikus liteke maila batean De Vega-Cuetos 1999.

39. Gero, esaldiko beste intonazio unitateekin batera, goragoko maila intonatiboa osa lezakeena. lua.

40. Ik. esateko, P. Price (eta beste)-ren 1991ko The use of prosody in syntactic disambiguation artiku-

41. AO (aditza-objektua segida). AX (aditza-zeinahi osagarri segida). OA / XA, alderantziz.

42. I, II, III ataletako esaldien artean ere badira egitura berau barne dutenak. Esaldi barreneko / barra etzanak intonazio unitateen arteko muga adieraziko du, eta hau parentesi artean emateak (/), mugaren zalantza.

43. (27a) bereziagoa da. 5.1. atalean aipatuko dugu.

44. Esaldi bateko (edo esaldi atal bateko) segidako gailurren altura gero eta apalago izatearena fenomeno ezaguna da hizkuntzetan barrena. Hala hitz egin ohi da oinarrizko maiztasunaren deklinazio prozesuez. Baita downstep edo catathesis-ez, eta aurreratu dira formula matematikoak ere oinarrizko maiztasunaren eroraldi horien neurria aurreikusteko. Ez dut uste, nolanahi, kontuak oraindik garbiegi daudenik deklinazio prozesu horien inguru, batez ere hauen aplikazio automatikoaren eremuei dagokienez. Edota, bestela, zenbateraino diren deklinazio prozesuak hiztunaren baitakoak, honek subjektiboki eragindakoak.

45. Lekukoaren ondoko jarduna arrunt ona gertatzen da. Beharbada kameraren aurrean izateak darama hiztuna intonazio unitate laburrak egitera lehenengoetako esaldi batean. Arrazoi bera (29)ko hiztunen esaldietan.

46. Unitate honi aplikatzen zaio nolabaiteko deklinazioa. Ez bigarrenari eta ez nabarmenegi ere hirugarrenari.

47. Eztabaidan alde bat utziko dugu Pabi izena, eta azken hiru hitzen gainean bakarrik mintzatuko gara.

48. Predikazio markorik gabeko esaldi.

49. Batuan : Niri Lurdes zait izena. Egitura, ezaguna dena mendebaldeko hizkeran. Ondarrun zait = gasta. Grafikoa ez da oso garbia gertatzen azken unitate honen inguruan (hiru s ahoskabe jarraian).

50. Merezi du ikustea $(39,40,41,42,43,44,47,49 b, 58)$ ko adibideak, eta $9 . k o(61 \mathrm{a}, \mathrm{b}, \mathrm{c}, \mathrm{e}, \mathrm{f}$; 62 ; $63 b, c, e, g, j, l ; 66 a, b, c, e, f)$

51. Izen-abizena aditzaren aurretik ematen den kasuetan gerta liteke ( 5 .en aztertu bezala) izena intonazio unitate independente batean emana izatea $(38 \mathrm{a}, \mathrm{f}, \mathrm{g}) \mathrm{n}$ bezala. Abizenak eta aditzak osatutako unitatea izango da pga. Kasuren batean gerta liteke $(38 \mathrm{~g})$, aditza eta aurreko osagaia intonazio unitate beregainetan emanak izatea (5.1.).

52. (38)ko eta antzeko esaldien aurrean, nolanahi, edonori sortzen zaigu tentazioa, aditz ondoko osagai horiek, aditza ezkutuko esaldi berritzat emateko. Beste gabe. Hori gertatzen da naiz itxurako aditz kopulatibo baten aurrean gaudelako, ondoko osagaiak ni subjektuari eginiko atribuzio berriak izaki (zalantza egin liteke halako aditz batek izan ote litzakeen osagarri atributibo bat baino gehiago elkarren lehian). Kontua da, halako esaldiak ezin ugariagoak direla antzeko egoeretan (gure corpuseko erdiak baino gehixeago), eta hiztunak beti esaldi bakar bati legokiokeen intonazio eremu batean ematen dituela (ik. irudiak). Halako atributu batekin aditza errepikatzen bada esaldi berria sortuz, intonazio eremu propioa eragiten du. Arazoari 
zabalago begiratu nahi izan diogu eztabaida honetan eta halako osagarriak tratatu beste zeinahi aditzen ondoko zeinahi osagarri balira bezala (objektu, leku, denbora, modu, kausa, helburu, $O$ osagarriak), ustez arazo predikatibo eta kognitibo bertsua erakusten dutela batzuek eta besteek : zarauztarra osagaiak Iñaxio nauk, zarauztarra esaldian ; edota datorren astera arte-k, Mikelekin etorri nauk / datorren astera arte esaldian. Guk esaldi bakar bezala tratatu ditugu.

53. 75ms-ak gainditzen ez dituzten 5 pausa zalantzazko barne. Esaldien $\% 81,25 \mathrm{ek}$ du pausa nabarmena, $75 \mathrm{~ms}$ baino luzeagoa, eta maizenik $100 \mathrm{~ms}(11,13$ irud.), $250 \mathrm{~ms}$ (10 irud.), $500 \mathrm{~ms}(12,14$ irud.) baino luzeagoa.

54. Baina esaldiak naiz aditzaren ondoren $825 \mathrm{~ms}$-ko pausa isila du, $380 \mathrm{~ms}$-ko betea, eta berriro $125 \mathrm{~ms}$ ko isila.

55. Esaldiaren beste ordenamendu batek ez lituzke ondorio berak emango. Daniela Bernaola / Orozkon jaioa naiz esaldiak, ezin izan du predikazio gune bakarra baino, hiztuna ase sentitu ezinda lehen unitatea jasotzean, predikazio marko, zeinen gainean egingo den bigarren unitateko predikazioa. Bitartean mezu hartzaileak ezin du lehen unitatea lan memoriatik atera, artean ezer predikatu ez delako.

56. Eztabaida sakonago baterako, Hidalgo 2000b, c.

57. Pentsa liteke maiz herriaren izenak $+-k o$ atzizkiak ohiko intonazio unitateen luzera hartzen duela, 4, 5 silaba, zeintzuk alkate(s)a hitzaren 4 rei erantsita intonazio unitate luze(egi) bat osatzen duten.

58. Fokalizatua eta aditzarekin intonazio unitate berean emana predikazio gunea osatuz,

59. Irudiari begira, beharbada suma liteke ni osagaian gailur txiki bat eta amaierako beberakadatxoa ere, ondoko unitatea hasi aurretik. Hau da intonazio kurba bakarra ni subjektuaren prokJitikotasun hipotetiko baten susmoa airean utz lezakeena, interpretatuz gero ni izenordea ez dela Juan Mari nukleoaren buruaurrea baino.

60. Aipatu dugu, hala ere (27 oharra), nola dioten Bizkaiko iparraldeko intonazio sistemaren aztertzaileek (Gaminde, Elordieta), sistema honetan ez ote den bi unitateen arteko halako bereizketarik egiten.

61. Halako hausnarketak ez dira inola berriak euskal eremuan (ik., esateko, Altube 1932, 102-3 ; 117).

62. Josu osagaia azpimarratu nahi izanez gero, derrigorrezko litzateke, hau ematea unitate buru eta aurreko osagaia unitate beregain batean (etxean osagaiak bi aukera lituzke : edo unitate berean agertu aditzaren isatsean, edo hirugarren unitate beregain batean, bigarren predikazio gune bezala : [NIK] [JOSU ikusi dut $0 \ddot{]}$

63. Kasuan badirudi izena ukan lokuzioak (izena + dut) aditz partizipio + aditz laguntzaile egituraren rol bera jokatzen duela (are intonazio aldetik ere : Josu izena dut Josu ikusi dut). Honen antzeko lirateke corpuseko Azpeitia eta Goizuetako esaldiak : Iñigo / Uribetxeberria izena diat, ... (Azpeitia - M) ; (...,ta, bueno,) Juantxo (/) Apezetxea izen dut. (Goizueta - M). Ez dugu uste hauek intonatiboki segidakoen oso desberdinak direnik : Iñigo / Uribetxeberria ikusi diat, ...; (..., ta, bueno,) Juantxo (I) Apezetxea izan dut etxean.

64. Kasuan, ni(r)i osagaiaren luzera $209 \mathrm{~ms}$-koa da eta i(r)i bokalarena, ( $r$-ren soinua imajinazio askorekin baino ez baita aurkitzen) $158 \mathrm{~ms}$-koa. Ez dakigu zenbateraino hitz egin litekeen azken silabaren luzatzeaz. Intonazio gailurrak, berriz, dena bat egiten du, etenik gabe, ni(r)i-ren azken bokalak eta Lurdes-en lehen silabak, nahiz artean zertxobait igotzen den honetan. Kasu honetan ere ez da erraz unitate arteko muga finkatzen.

65. naiz aditza (ohiko 120 - $150 \mathrm{~ms}-k$ o iraupena) daramaten 22 esaldietako 5ek bakarrik du 200 ms baino gutxiagoko iraupena (lek $150 \mathrm{~ms} ; 2 \mathrm{k} 190 \mathrm{~ms}$; eta beste $2 \mathrm{k} 180 \mathrm{~ms}$; azken hauetako batek $30 \mathrm{~ms}-\mathrm{ko}$ pausa isila ere du ondoretik). 5 esaldik 200-249 ms bitarteko iraupena ; $2 \mathrm{k} 250-299 \mathrm{~ms} ; 8 \mathrm{k} 300-399 \mathrm{~ms} ; 2 \mathrm{k} 400$ ms baino luzeagoa.

66. Hizkuntza hauek, hala ere, badute aditz aurreko subjektua fokalizatzeko gaitasunik (ingelesez, portugesez eta gaztelaniaz bederen ; frantsesez kasu honetan askoz maizago erabiltzen dira beste fokalizazio estrategia batzuk). Kasu hauetan, ez dirudi desberdintasun nabarmenegirik legokeenik hizkuntza hauek eta euskararen intonazio ereduen artean : JONEK egin du hori / john did that / JON ha hecho eso. Ez dute horregatik hizkuntzok euskararen eraginik. Bai, ordea, OA/XA hizkuntza antolamendu aukera orokorrena.

67. Besterik da gaur eguneko zenbait ordenamendu, azentuazio eta intonazio joera arrotzen zabaltzea gazteen artean : Naiz JON [soy YON] itxuran ahoskatua ; edo Mikel DAGO ? edo Dago MIKEL? [Está MIKEL ?] [Mikel ESTÁ ?] itxuran ahoskatuak ; eta antzeko hainbeste. Non bukatuko da eboluzioa ?

68. sMerezi du liburu osoari ere gainbegiratu bat egitea, artikuluan jorratzen ari garen gaiaren inguru. 
1. Ifonu // 60-260 /2 // 644, ,5 ms

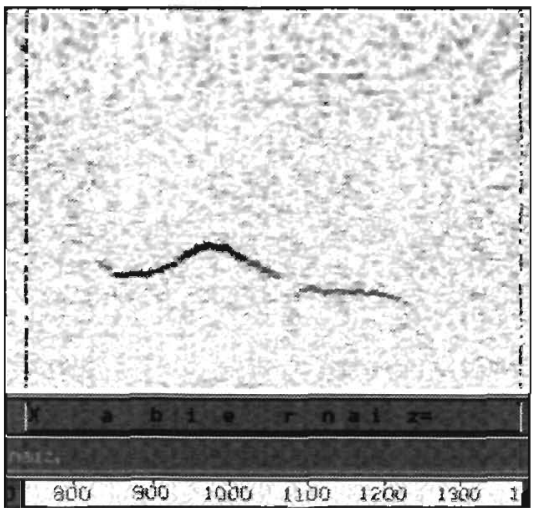

Cud Kabler mak // Echloar

3 ladnu // 180-300 kp // 510,19 as

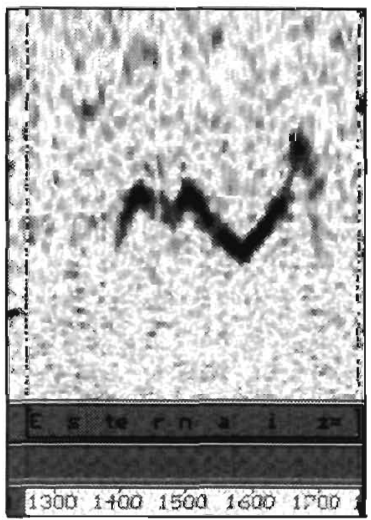

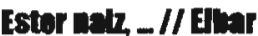

\section{IfODU // 60-260 th // 927,04 ns}

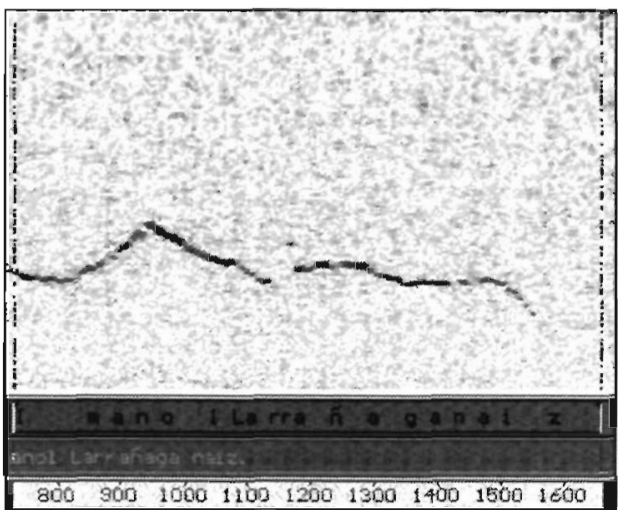

[M] Inanol Lorraitoganch // Egdhe

4lachu // 60-260 /i // 67,81 ms

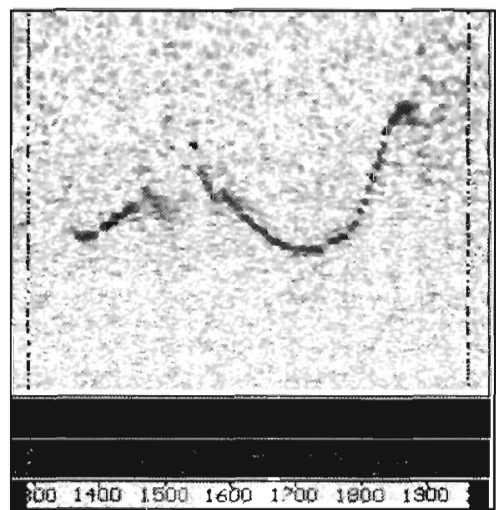

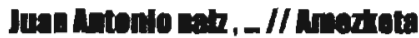

5 IRUAL // 62-269 /z//1.133,12 ms

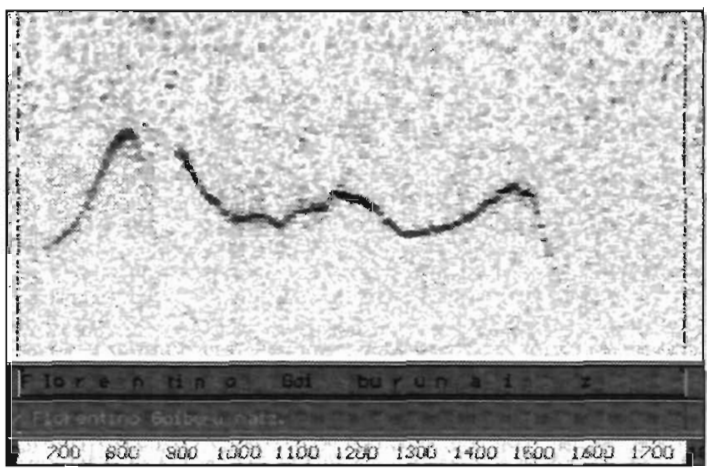

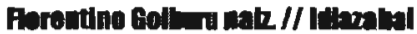


6 IROUL // 60-260 th // 1207,49 ms

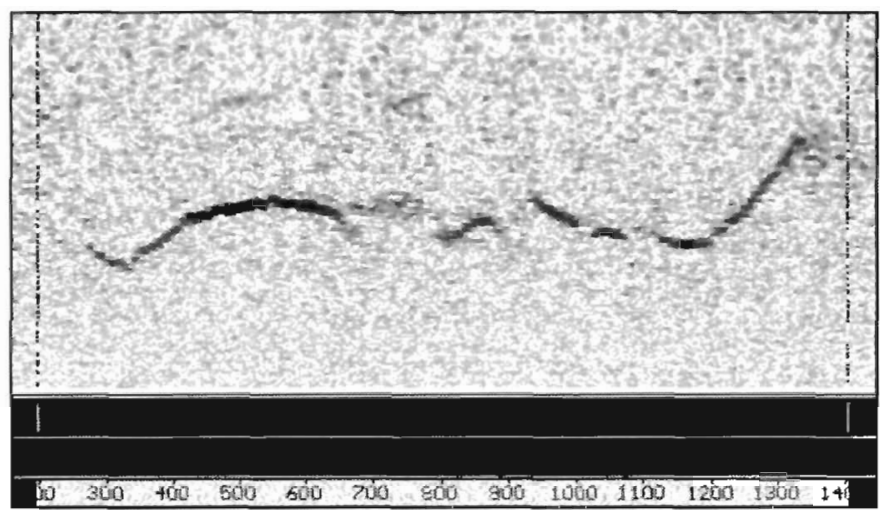

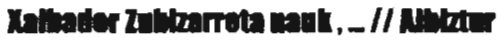

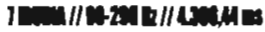

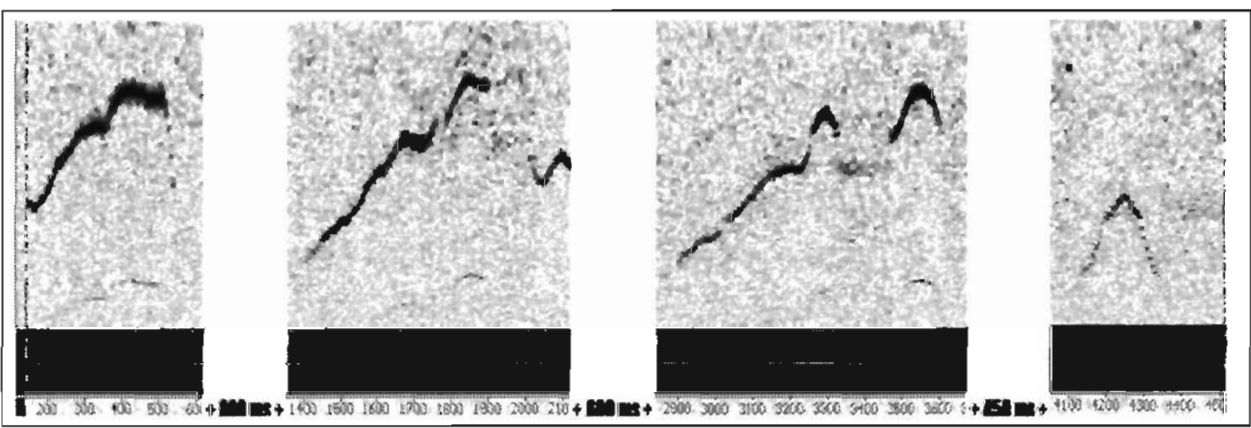

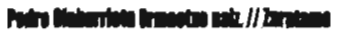

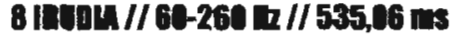

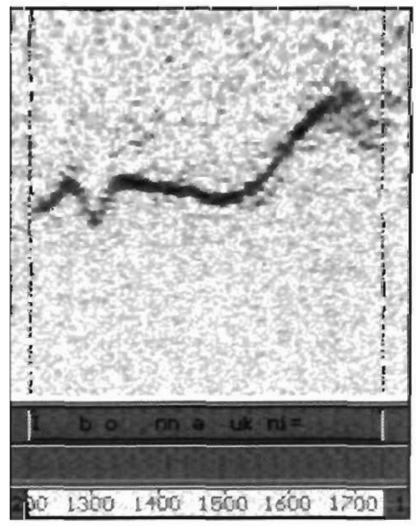

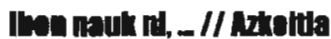

9 InUDL // 6e-260 Bh // 843,75 ms

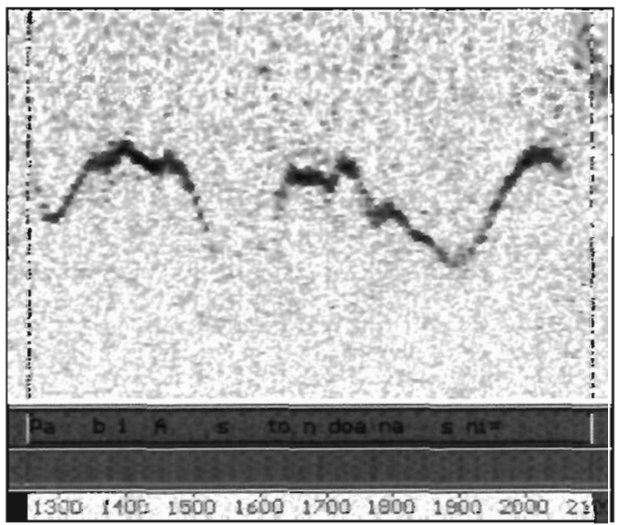

Fanl Istondoa mes ah - // Lrath 


\section{Itunu // 60-260 kn // 1627,51 ms}

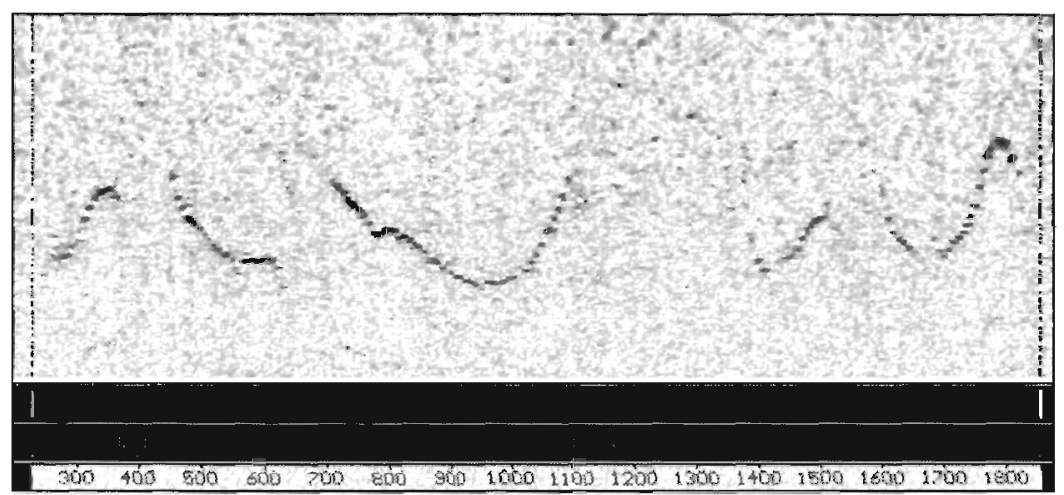

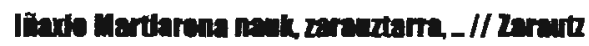

\section{t1LOn // 199-890 k // 1890,72 ms}

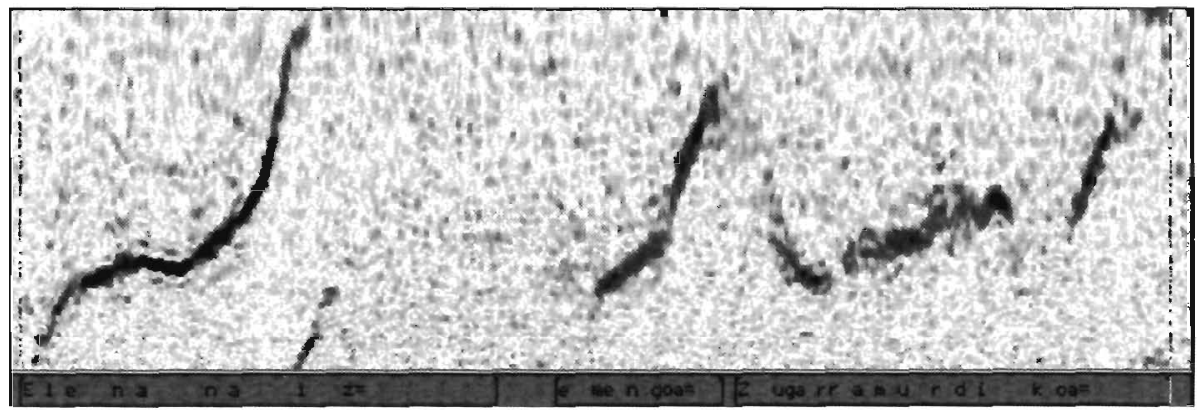

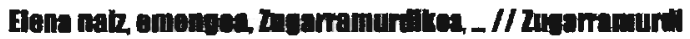

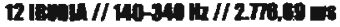

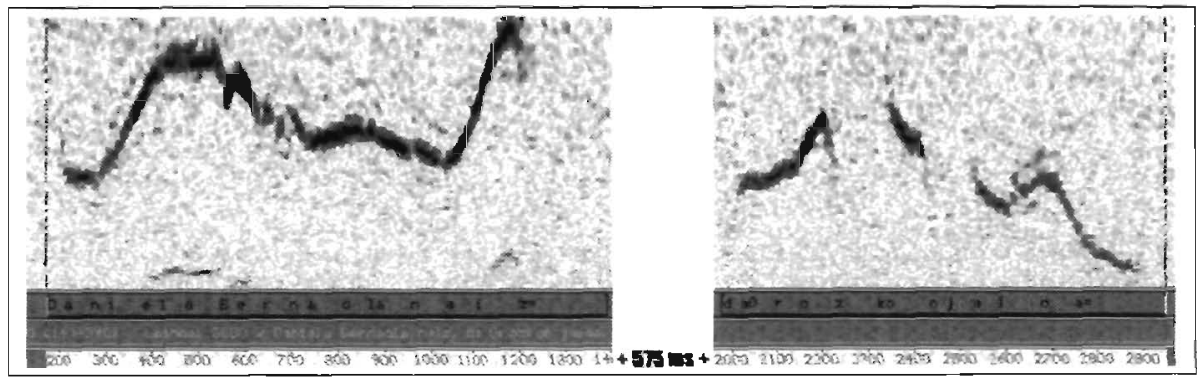




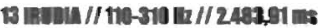

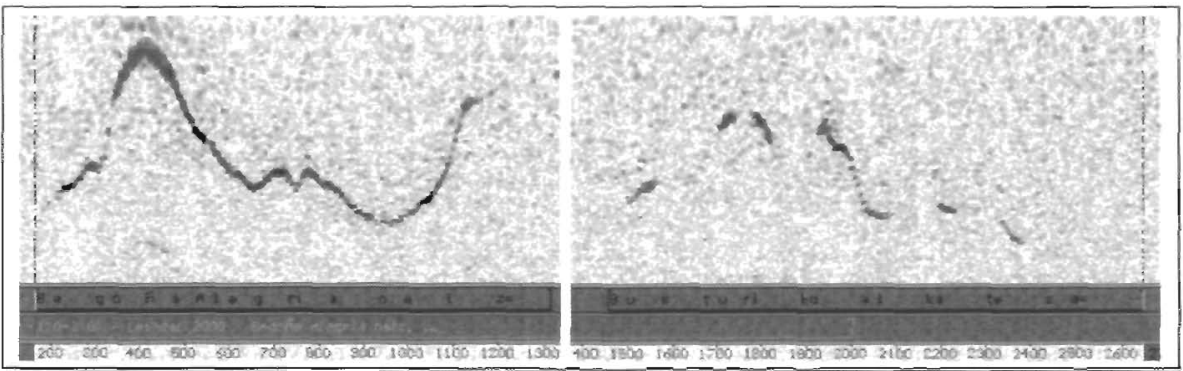

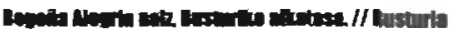

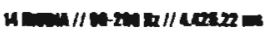

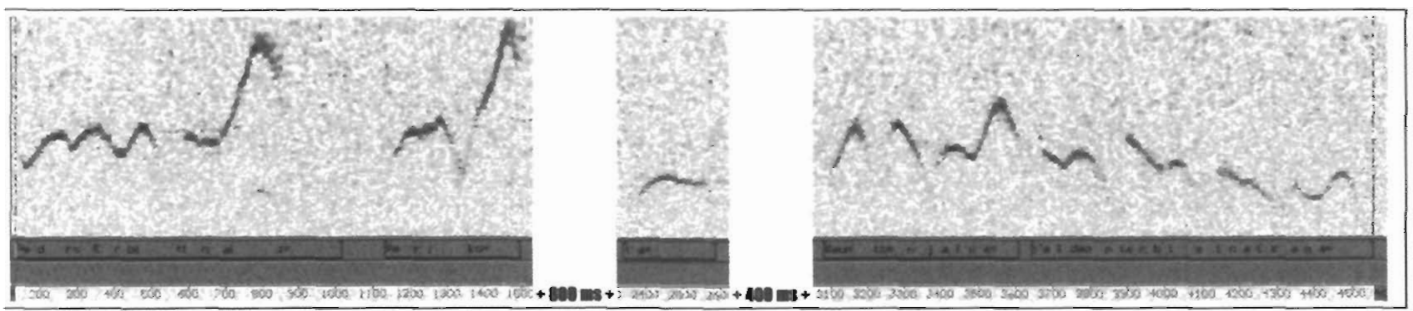

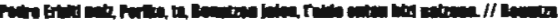

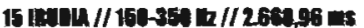

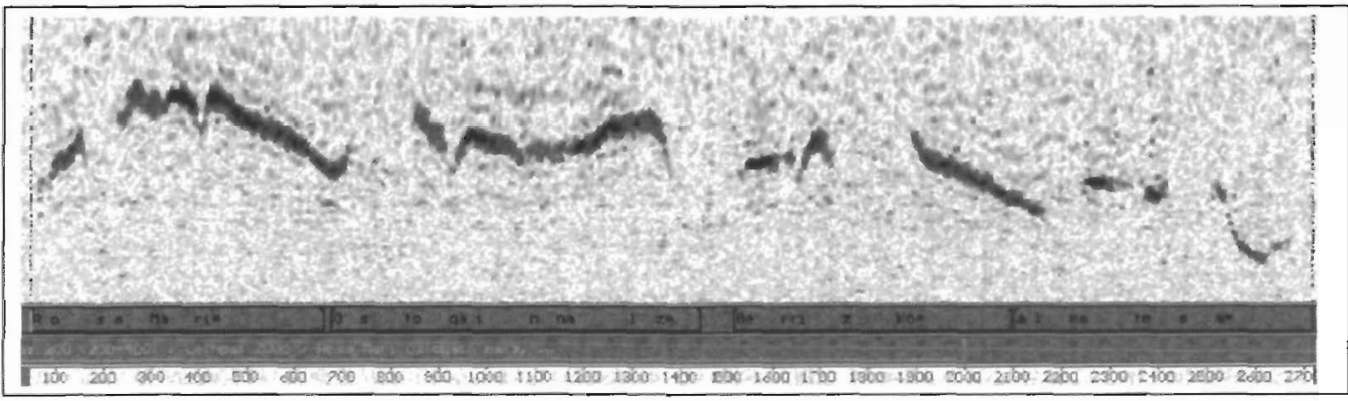

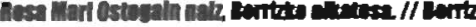

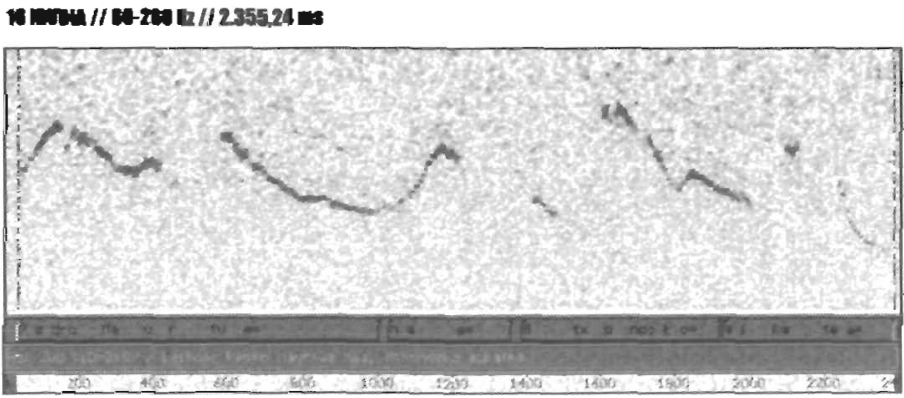

Pedre llaurtua nas, lbcondete allutec. // Muondo 


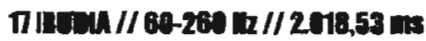

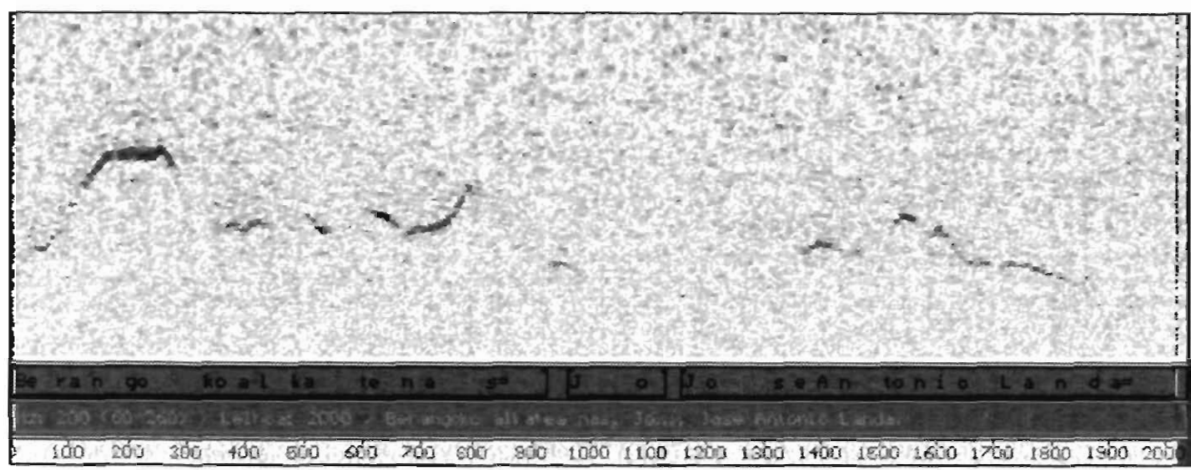

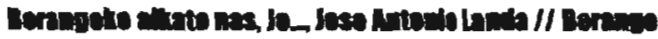

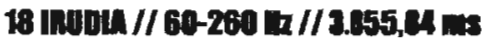

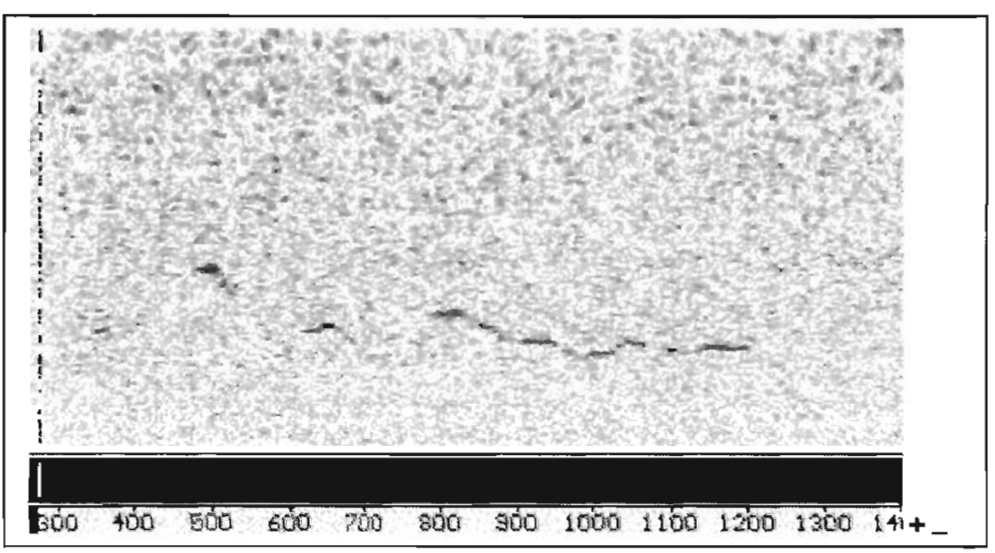

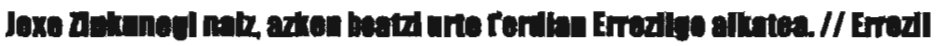

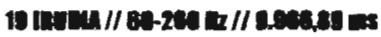

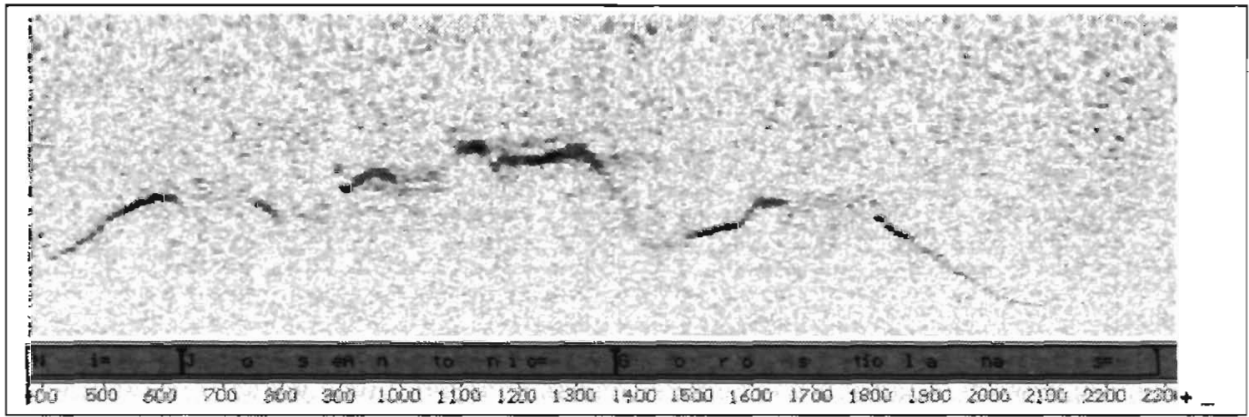

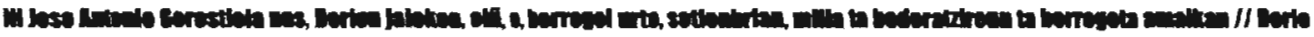




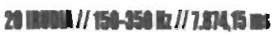

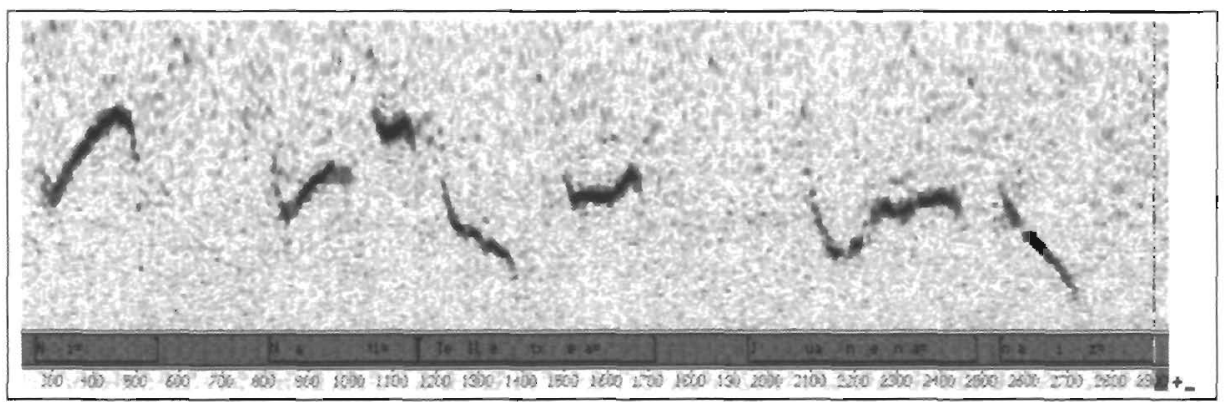

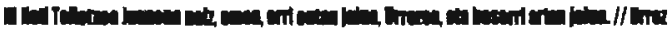

\section{IRU日L / / 100-300 ㄱ / 1796,22 ms}

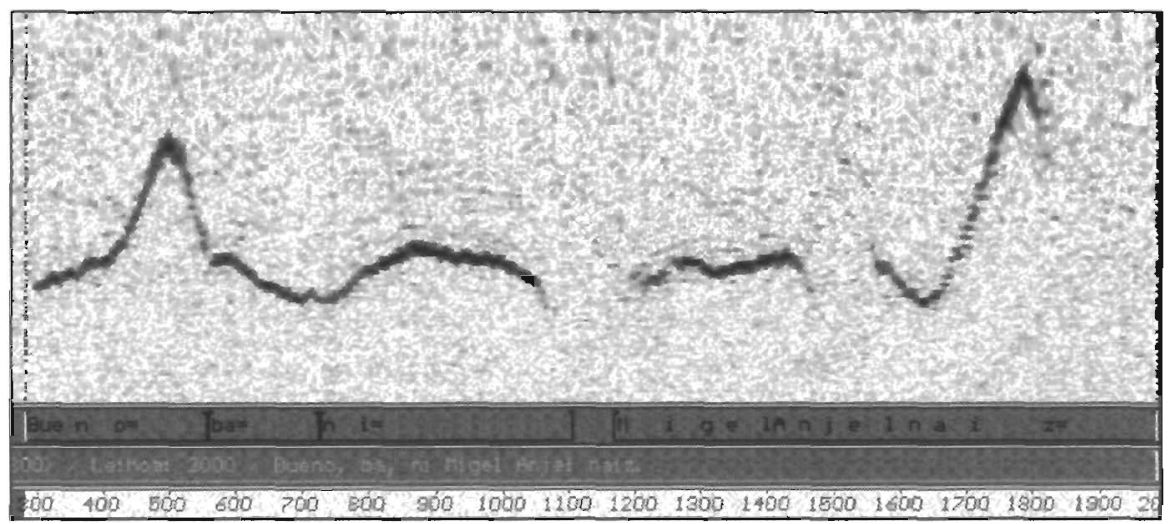

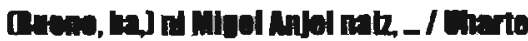

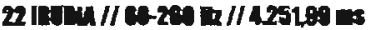

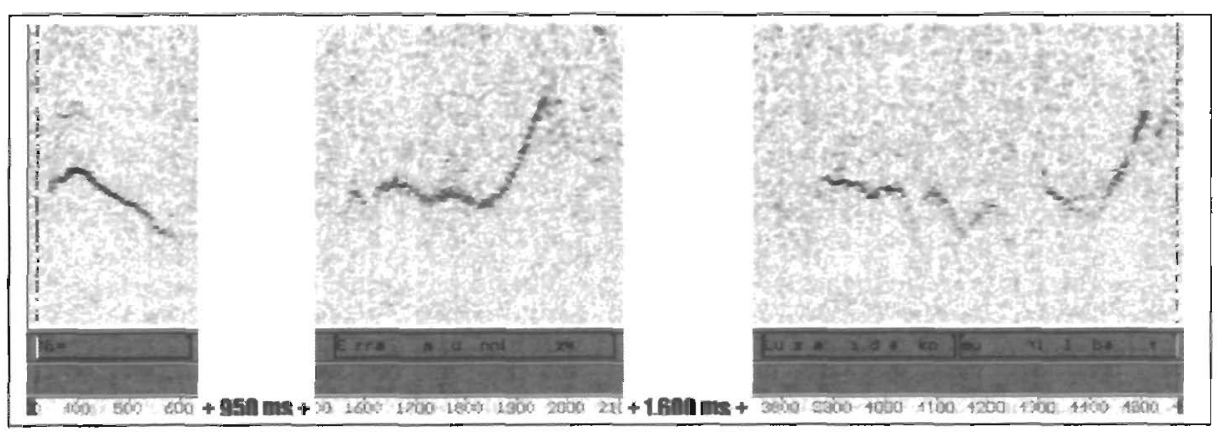

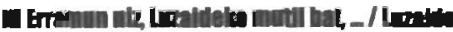




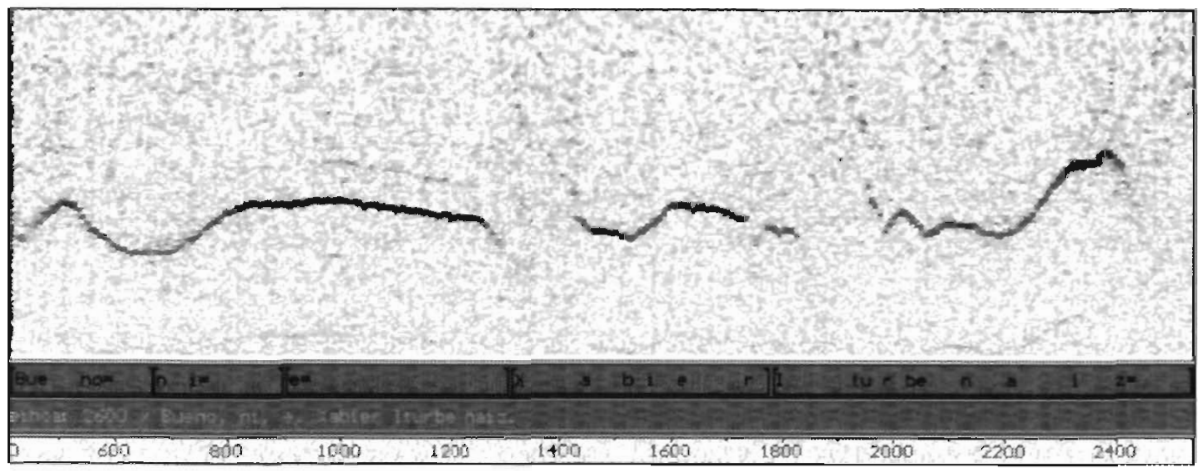

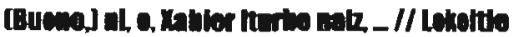

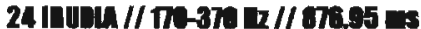

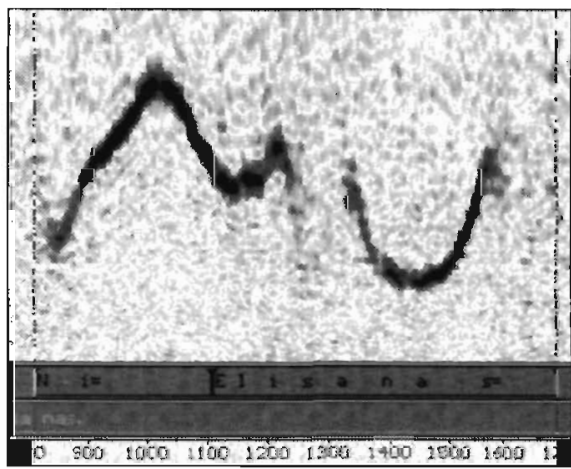

W. Elsin ags, _ // Rustu ia
25 lionu // 17-97 th // 95522 ns

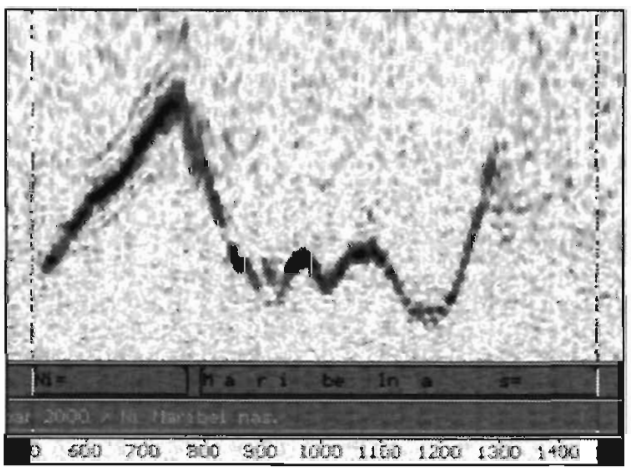

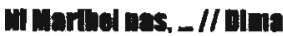

\section{IRUaU // 170-370 Hz // 1.396,50 ms}

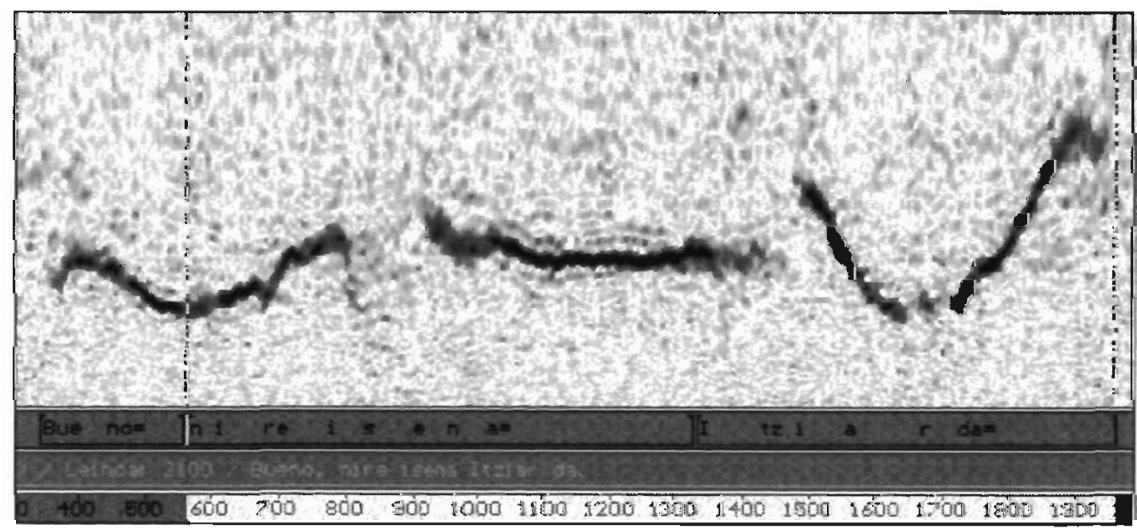

[Buono,] nire Isena lotar dh, _ / / Oodam 


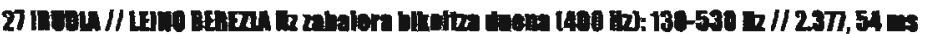

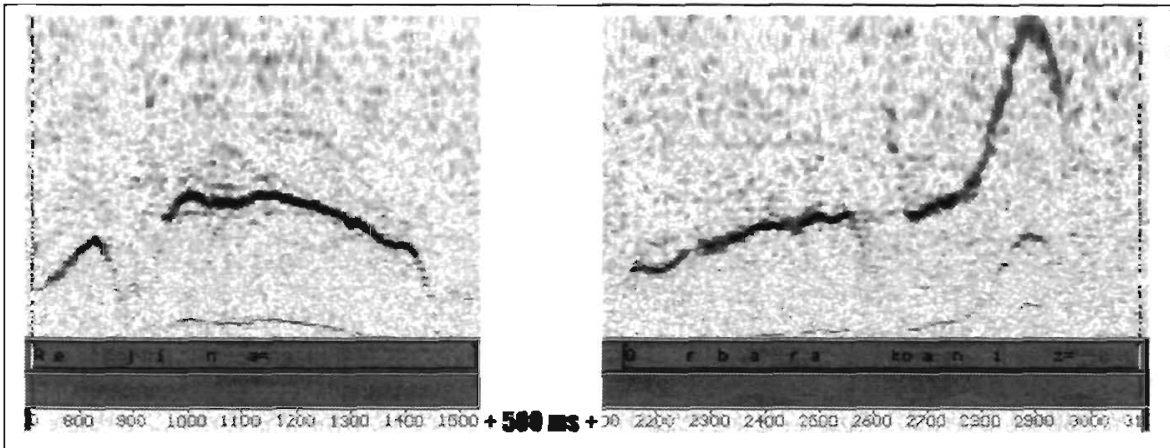

Bellan, Ortanitas al, _ // ettarn

\section{8 andu // 150-350 k/ // 892,78 ms}

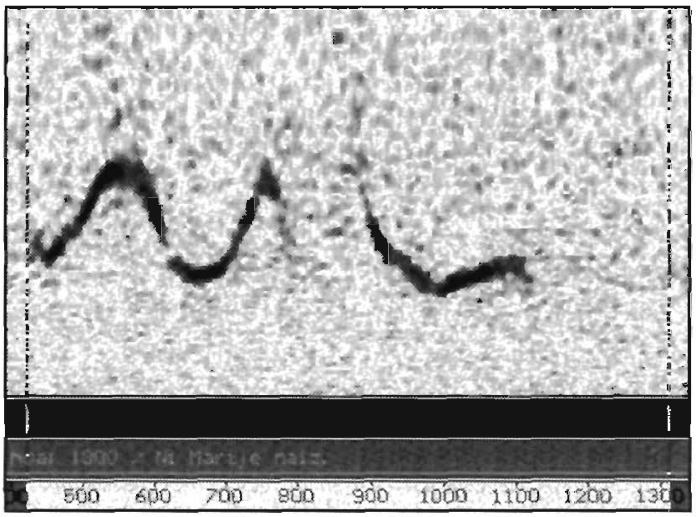

\section{Larlo mak // ofiot}

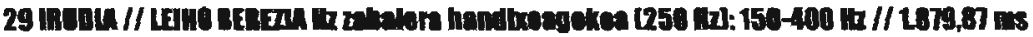

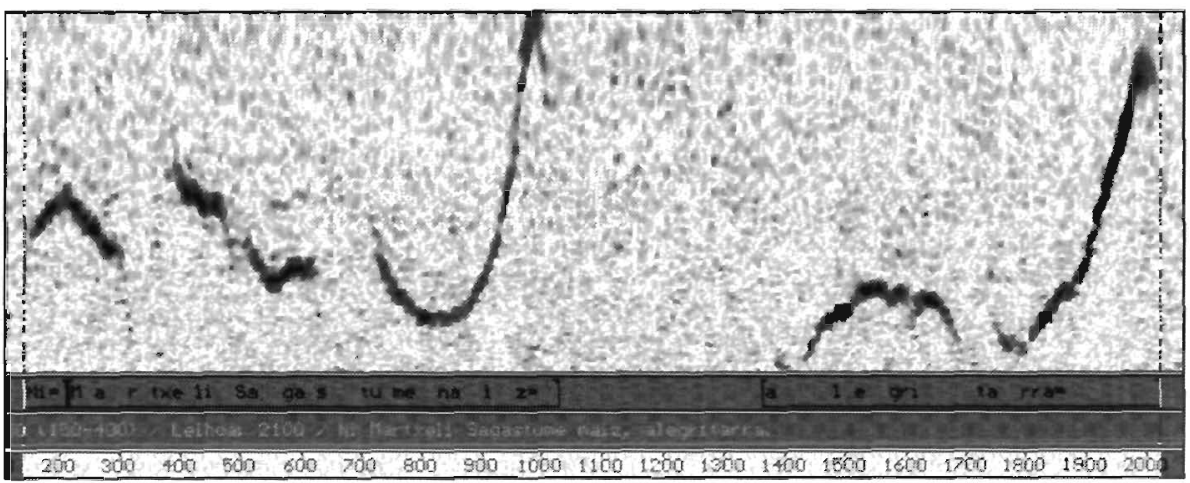

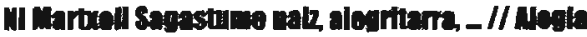




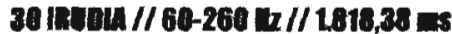

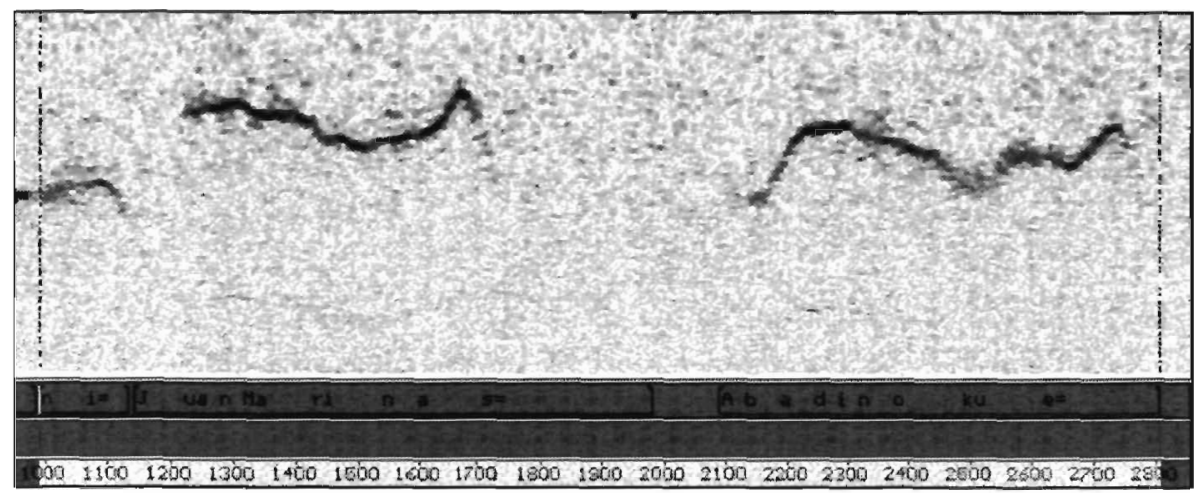

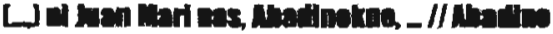

\section{10014 // 60-269 L2 // 71,22 ms}

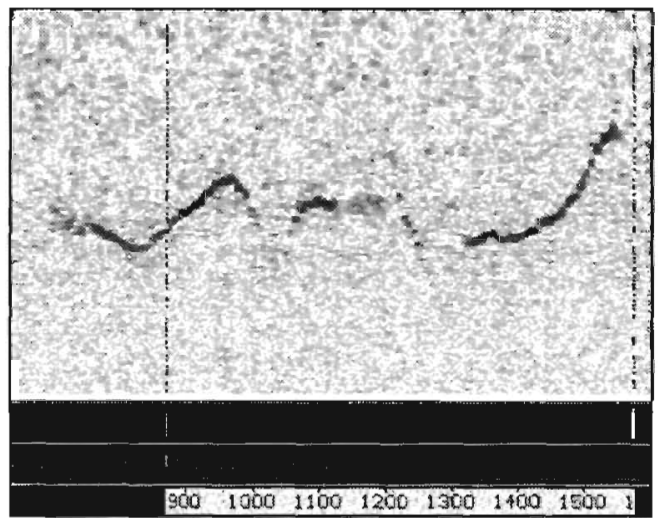

[Bucno, nIt) bsu bona dit _ / / Zottra

\section{2 lanun // 150-350 /h // 1590,07 ms}

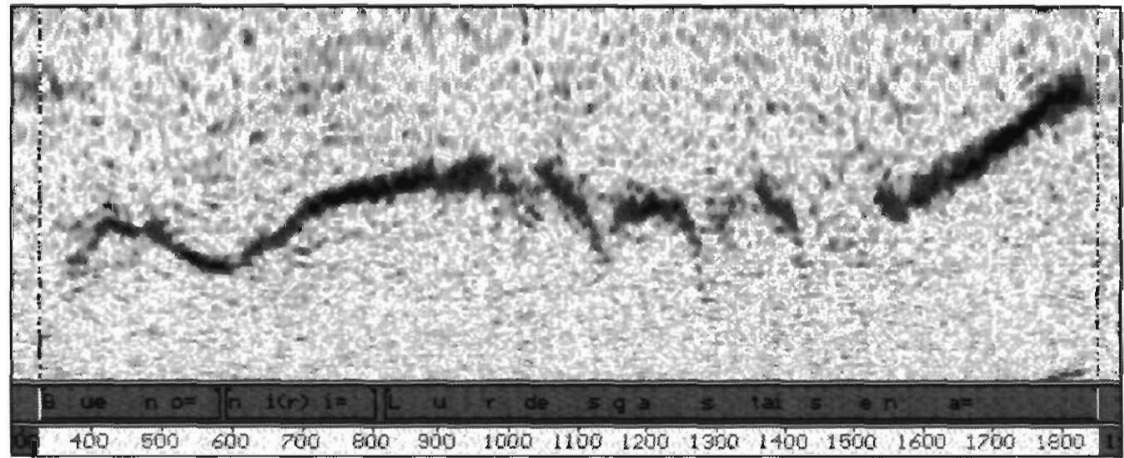

[Brono, nlir)l Lurlos gasth keng, _ // Ondarm 


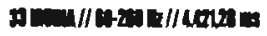

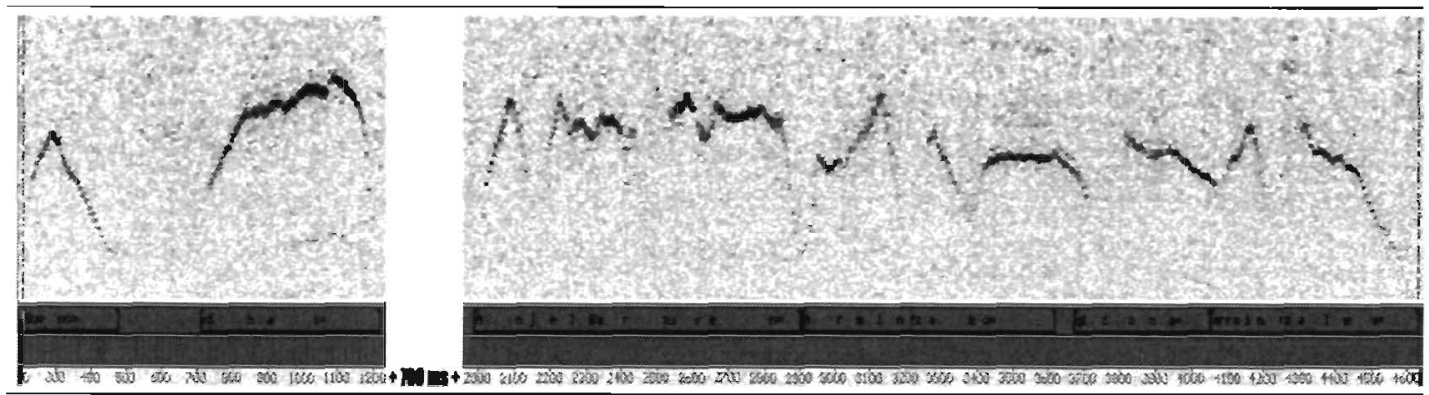

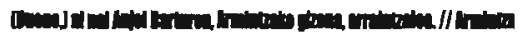

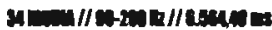

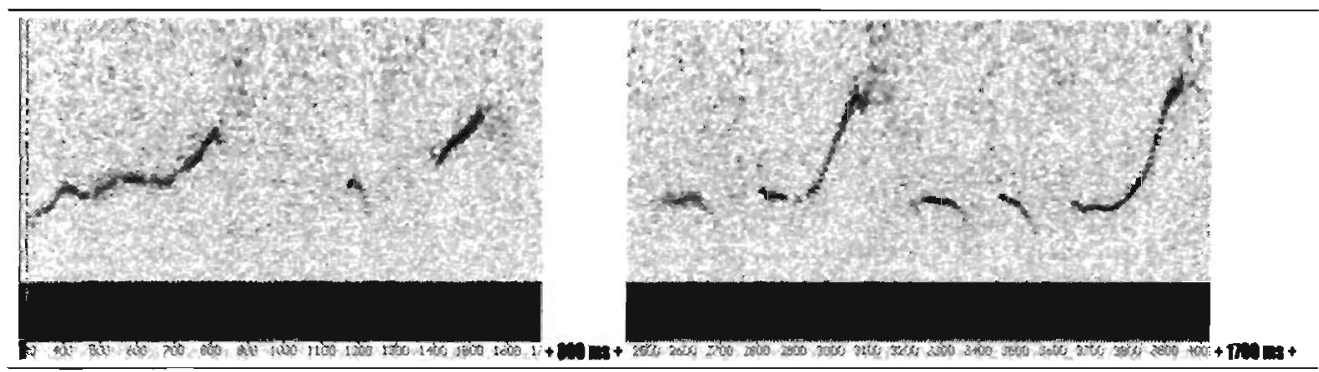

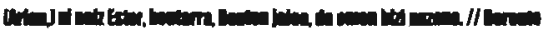

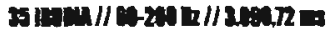

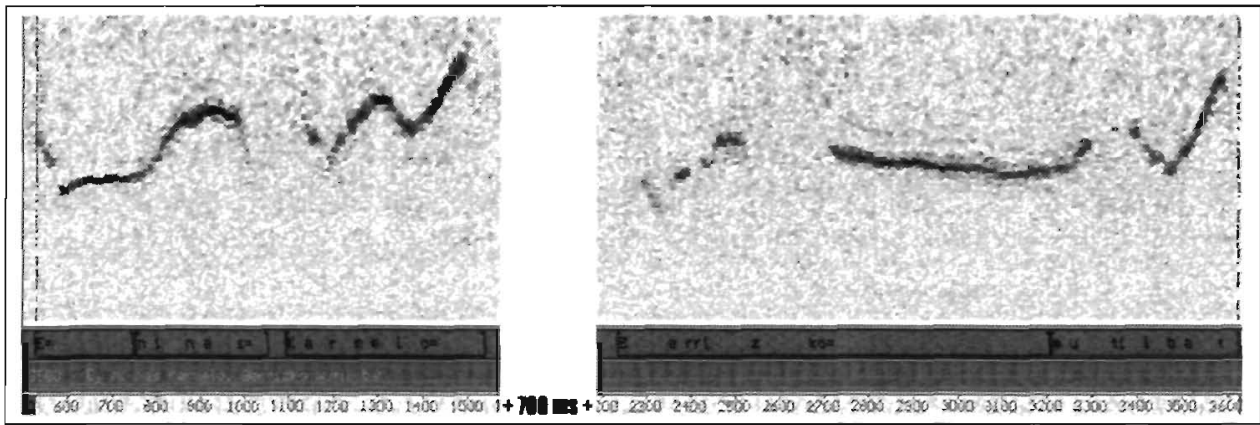

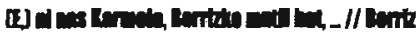




\section{Lund // 94-290 b/ // 1.06106 as}

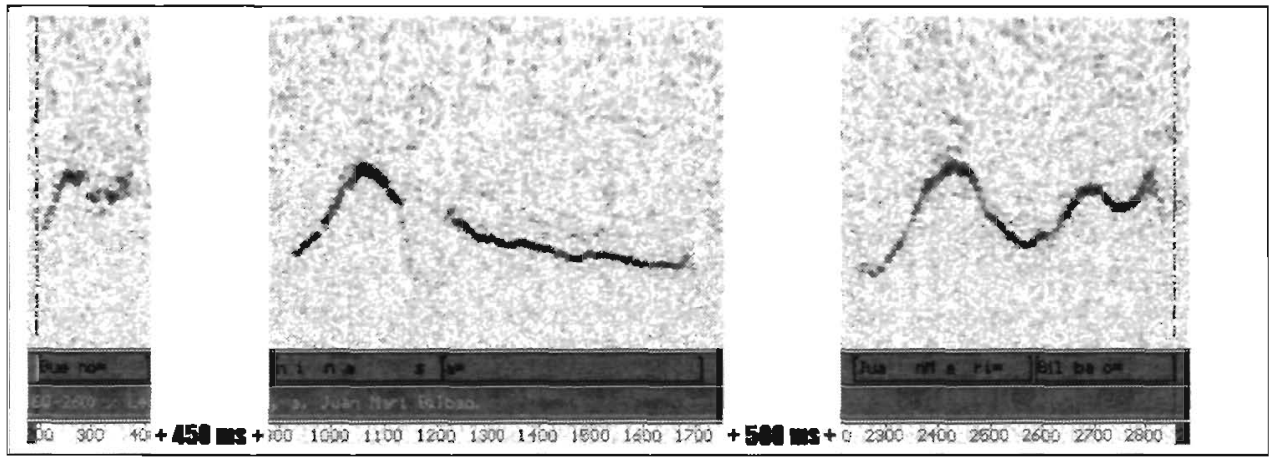

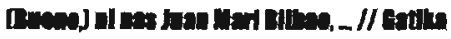

\section{IRUDL // 125-925 m/ / 1.835,21 ms}

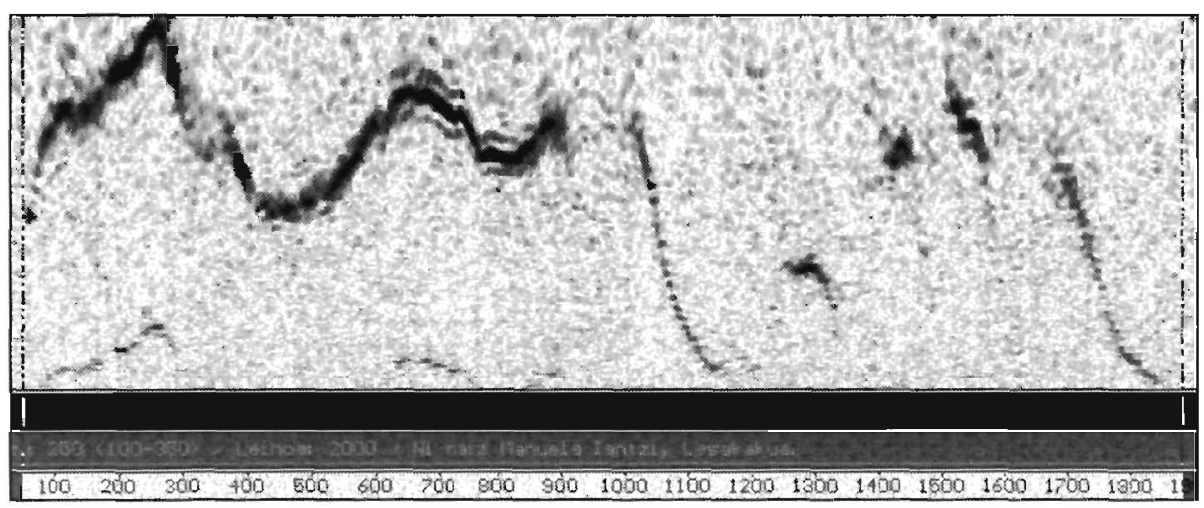

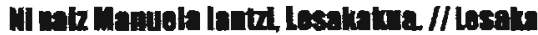

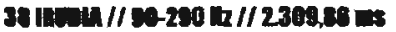

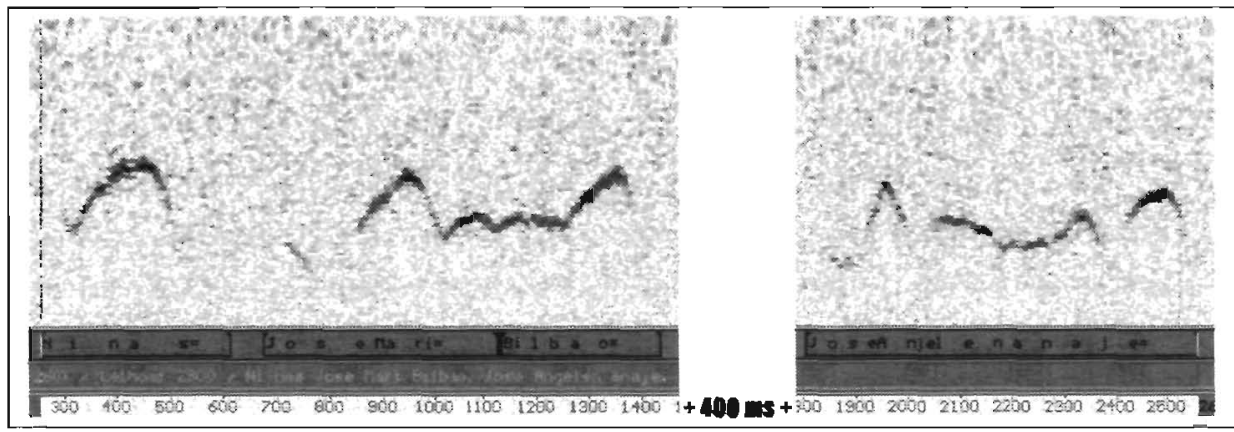

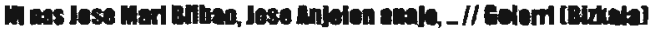




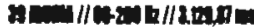

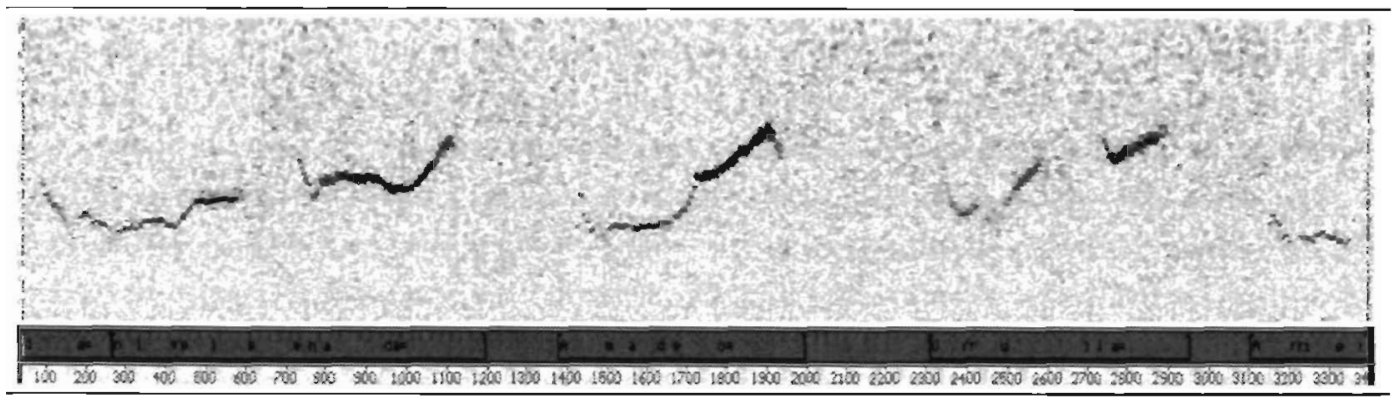

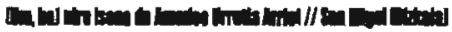

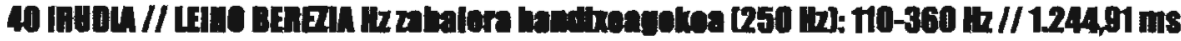

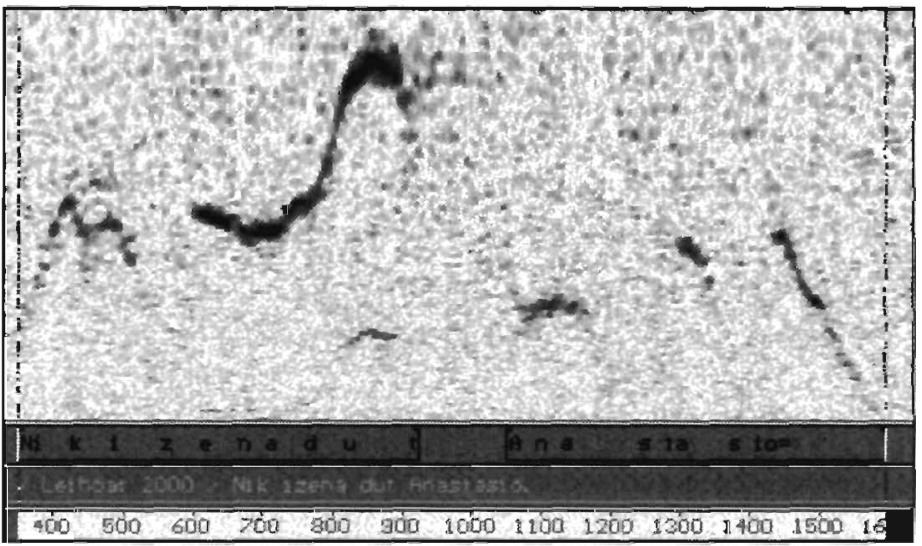

Wir hon tut Lastasio. // Bdiase

41/2014 // 60-260 /h //765,81es:

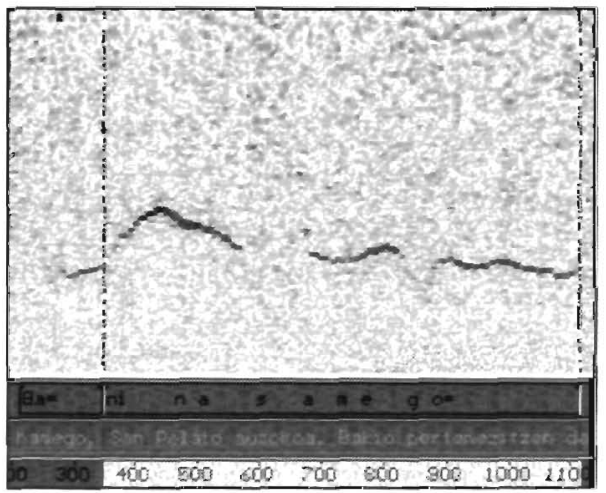

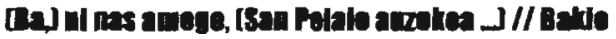




\section{IBODL // 60-290 /2 // 712, 4 ms}

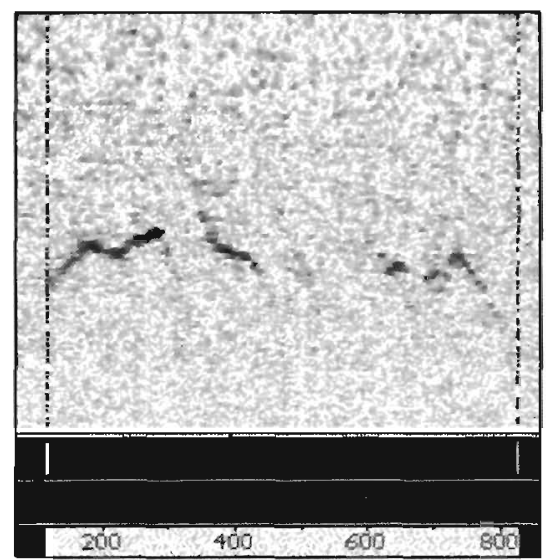

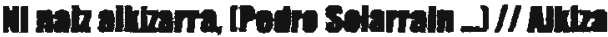

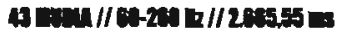

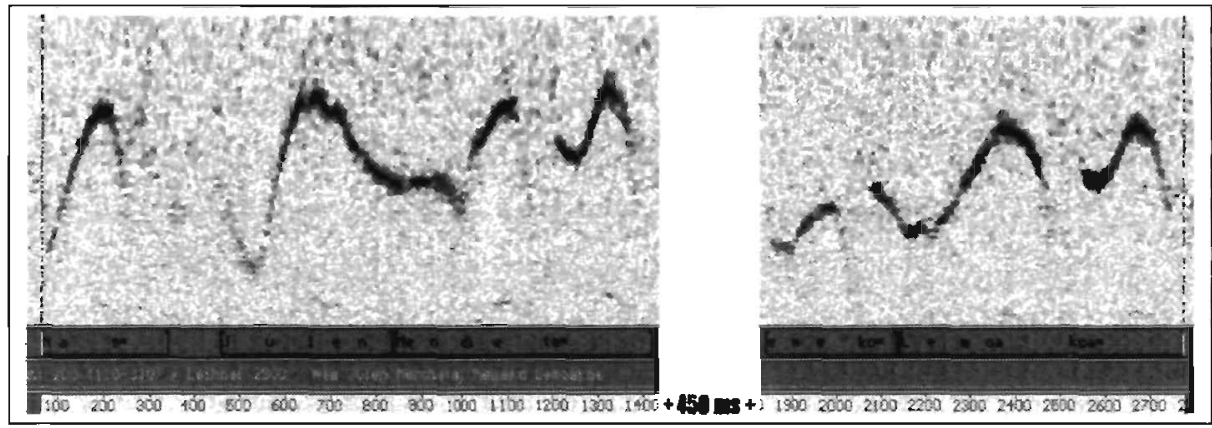

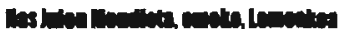

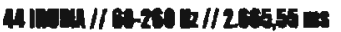

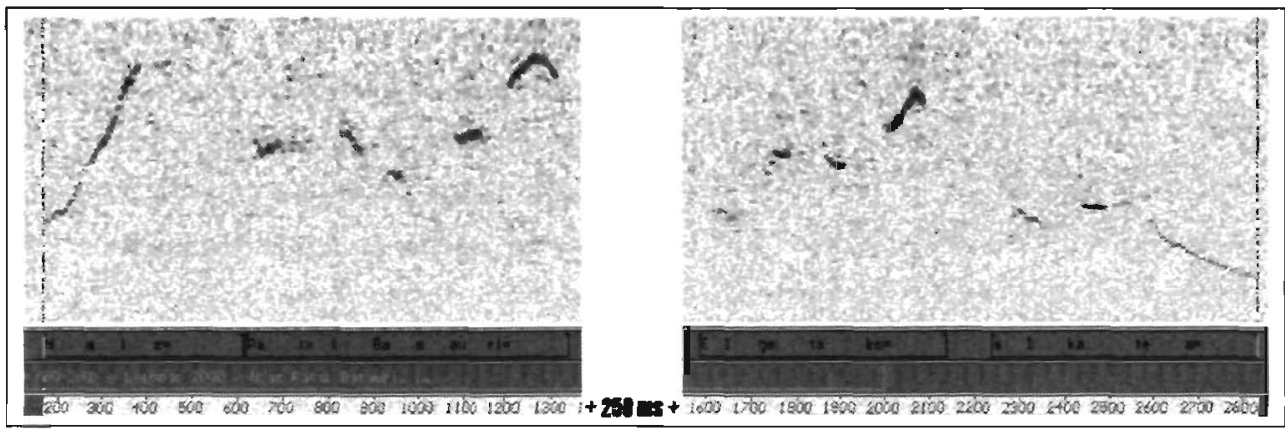

